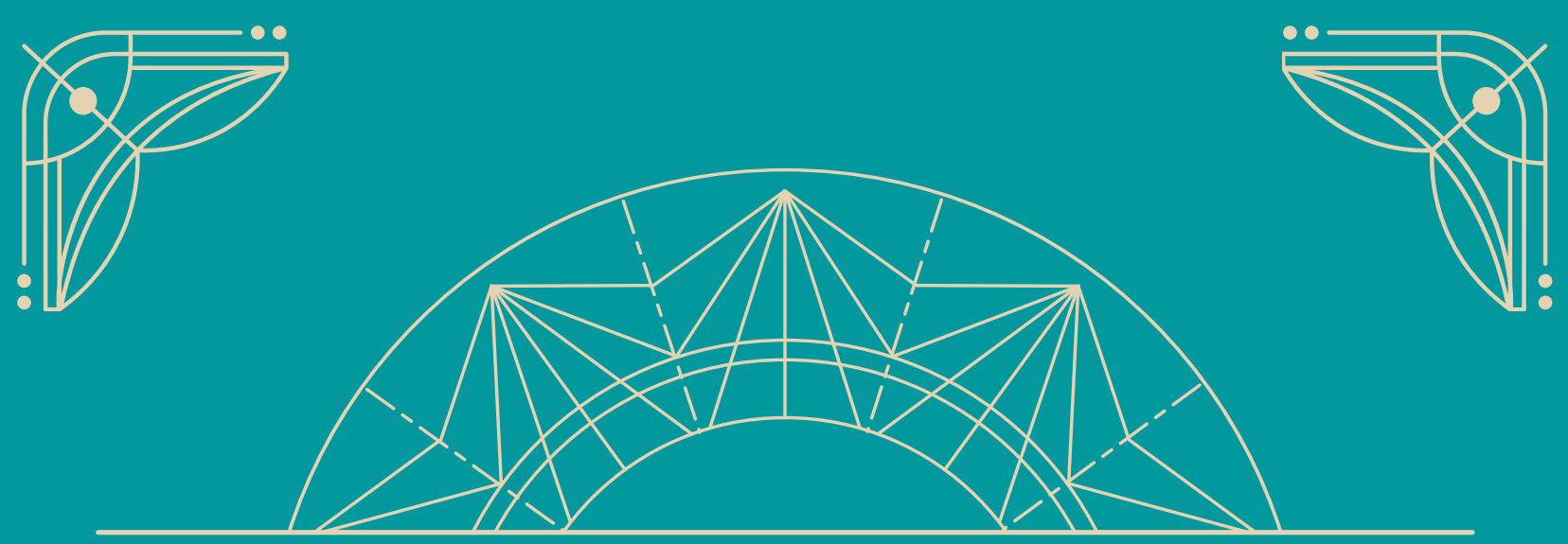

\title{
Carnavalito Por la Vida y el Amor
}

PROPUESTA PARA FOMENTAR LA SIGNIFICACIÓN DEL CARNAVALITO, Y POSIBILITAR NARRATIVAS DE MEMORIA CULTURAL, POR MEDIO DE LA IMPLEMENTACIÓN DE TÉCNICAS Y HERRAMIENTAS DE COMUNICACIÓN AUDIOVISUAL.
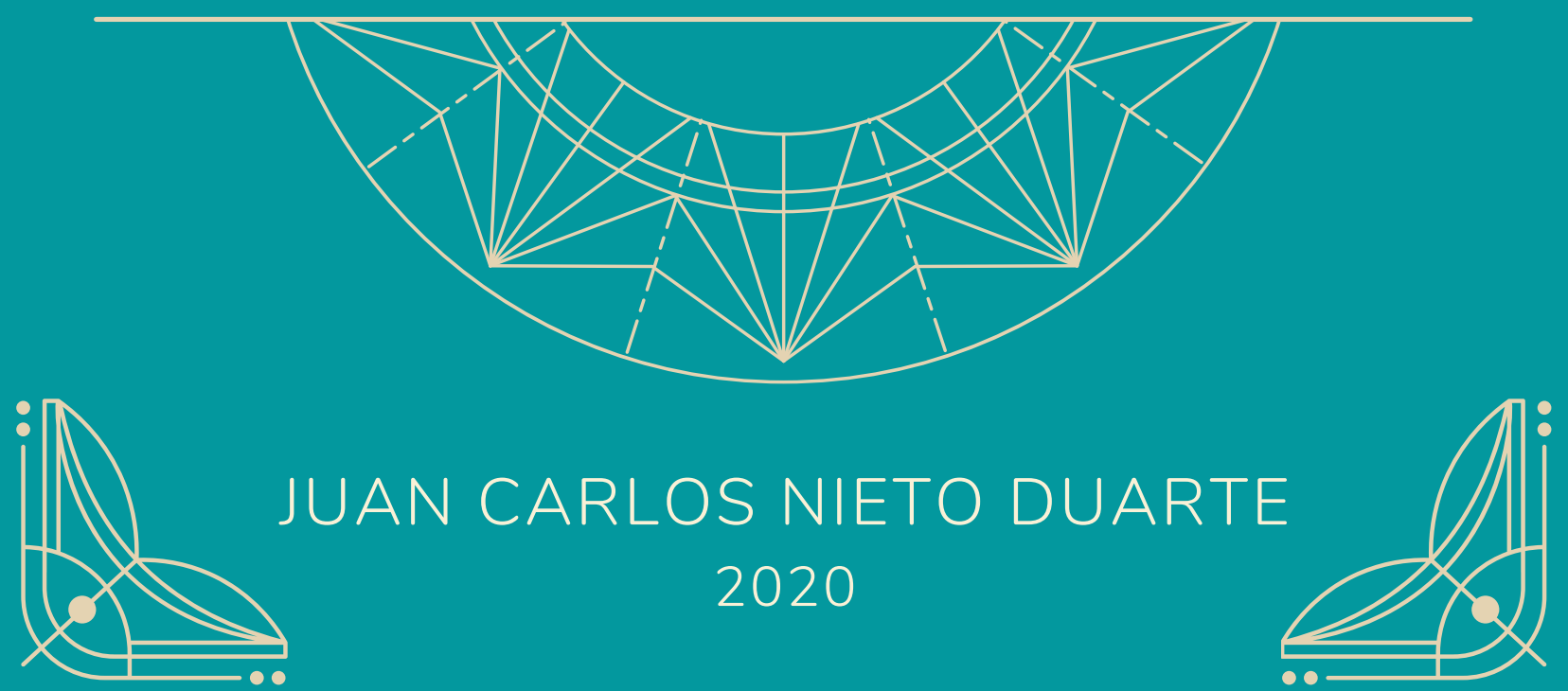


\section{Carnavalito Por la Vida y el Amor.}

\section{Propuesta para fomentar la significación del Carnavalito,}

y posibilitar narrativas de memoria cultural, por medio de

la implementación de técnicas y herramientas de

\section{comunicación audiovisual.}

Lic. Juan Carlos Nieto Duarte

Directora: Dra. Cecilia Ceraso

Maestría en Planificación y Gestión de Procesos Comunicacionales

PLANGESCO

Facultad de Periodismo y Comunicación Social Universidad Nacional de La Plata

UNLP

Contacto:plangesco1@perio.unlp.edu.ar

La Plata- Buenos Aires-Argentina 


\section{A modo de prólogo}

Quiero plantear que, tras avanzar el tiempo en mi vida personal y profesional, me he dado cuenta que persistir en excluir los aportes de lo académico en la realidad cotidiana y los aportes de la vida cotidiana en lo académico, hace que se pierdan nuevas posturas en la visión de diferentes temáticas, buscando sostener la necesidad de apartar estas dos dimensiones.

Los humanos no miramos al mundo con un filtro definido y segmentado por fracciones seleccionadas de nuestra experiencia sino por la totalidad de esta, aunque no tomemos conciencia de esto o, aunque lo neguemos por una pretensión de selectividad en la postura. Esto somos todos los humanos, una complejidad, un ser holístico, multidimensional. Así, con esa complejidad es que nos levantamos todos los días a ver el mundo.

Ahora bien, quiero que nos situemos en una carretera de Suramérica, recorriendo por varias semanas lugares ajenos, pero que en algún momento se sienten propios. Apenas sintiendo el cambio tenue de los acentos entre una ciudad y la anterior o la siguiente. Viajando de día, viajando de noche, caminando sin saber en dónde se está, pero con la ilusión de encontrarse nuevos lugares, sintiendo miradas de reojo cuand o se habla y se hace presente tu propio acento, que ya no es el "normal" y dominante, ahora es el diferente.

Así, de lugar en lugar, de charla en charla, de foto en foto, fue como llegué a la frontera entre Bolivia y Argentina. El cruce entre Villazón y la Quiaca caminando fue el que me llevó a una venta de tiquetes para los buses o bondis que llevaban a los viajeros de la frontera la capital argentina. Después de tomar el transporte que me llevaría a la ciudad autónoma de Buenos Aires, me senté por horas a apreciar la vista por la ventana, ejercicio habitual cuando se viaja por gusto. Observé con un placer increíble las montañas de colores del paisaje Jujeño, adornado este paisaje, por fortuna para mí, por el sol del atardecer, ese sol naranja que llega de lado. Desubicado por los cambios de usos horarios de los países, noté que estábamos próximos a las 8 de la noche pero que aún el sol iluminaba. Que extraño escenario este.

En un punto del recorrido, ya de noche, el bus se detuvo en la capital de la provincia e hizo que todos sus ocupantes se bajaran en una plaza con la promesa de que se iba a cambiar de bus para continuar con el viaje. Más de cuarenta personas, entre mayores, de la tercera edad y niños pequeños, con nuestros equipajes en el suelo observamos como el bus se iba y nos dejaba ahí a la intemperie. Sin entender lo que pasaba, empezaron las charlas, el voz a voz que planteaba que era una práctica habitual la estafa de las empresas de trasporte, las cuales vendían unos planes de viaje pero que los incumplían para hacerse con el dinero.

La explicación de uno de los viajeros, en una de esas charlas dadas por la situación particular, contextualizaba todo el momento. Este viajero, un profesor peruano ahora radicado 
en Buenos Aires, que volvía de una visita a su país, conocía por experiencia propia esta práctica y nos contaba que las empresas de transporte aprovechaban que la mayoría de viajeros eran personas migrantes del interior de Bolivia, Perú e incluso Paraguay, personas que por su condición de migrante buscaban tener el menor conflicto posible con personas de este país y que por lo tanto preferían callar ante tal abuso. Ante estas charlas se fueron sumando experiencias y anécdotas. Se fueron cruzando los nombres de los viajantes y fueron aflorando emociones suscitadas por la situación. Enojo, frustración e incluso una que otra risa se escuchaba por lo absurdo del momento. En medio de este diálogo, entre los ocupantes del bus que no estaba, me encontré en medio de un grupo de jóvenes adultos integrado por cuatro argentinos, un peruano, un británico y dos colombianos, siendo yo uno de estos últimos. Fue una sorpresa para mí encontrarme con otro colombiano en tal momento.

La noche continuó con la promesa de que el segundo bus llegaría, pero pasaron las horas y no llegó, pasó la noche entera y no llegó. Agrupados aun en una plaza nos fuimos apartando del punto central, fuimos acercándonos a los negocios más próximos en búsqueda de una bebida caliente, un cigarrillo o algo de comer. En medio de esta exploración fue que empecé a hablar con el otro colombiano en esta situación, se trataba de Fernando Cardona, un politólogo que viajaba desde Guayaquil a Buenos Aires a visitar a una amiga. Me contó que era uno de los fundadores de una iniciativa comunitaria en barrios del sur de Bogotá, me dio una de sus tarjetas y me invitó a que en un futuro visitara su iniciativa. También estuvo la historia de uno de los argentinos del grupo que volvía de vivir en Nueva Zelanda y que viajando desde México hasta su Argentina natal decía no haber sido estafado sino lamentablemente en su propio país. Y así llegó la mañana y el medio día esperando, cuando en menos de tres minutos apareció un bus de la nada e indicó a los abandonados de la noche anterior que subieran rápidamente cobrando una cuota adicional a lo ya pagado el día anterior. La algarabía del momento confundía los insultos de los indignados con la prisa de los que no dudaban en subir sin protestar. Un tire y afloje entre la muchedumbre se intensificó cuando los empleados de la empresa de trasporte iban a cerrar las puertas afirmando que se marcharían con los que ya se habían subido; pero en un reconteo con los que llegamos la noche anterior faltaba uno y no se podía dejar botado, faltaba el profe, no aparecía, se había ido a almorzar y en su exploración se alejó de la plaza, nadie lo encontraba y la tensión se empezó a incrementar, amenazas iban y venían y el británico no entendía nada. En el momento más álgido de la disputa apareció corriendo el profe, cruzando la plaza, una algarabía como un gol en una final se metió al bus con todos sus ocupantes. La pelea siguió adentro, pero se fue atenuando con el pasar de las horas. Ya por lo menos estábamos en 
camino a nuestros destinos. Llegamos a la ciudad de Buenos Aires. Así como nos subieron en San Salvador de Jujuy, así nos bajaron en la Plaza de Once, en pocos minutos y sin dejar rastro después del desembarco. Cada cual continuó hacia su destino.

Casi un año después de esa llegad a me encontraba en la PLANGESCO. Sentado, esperando a que iniciara la primera clase, con mucha intriga por lo que vendría. Aún recuerdo que llevaba un libro para el viaje desde Buenos Aires hasta La Plata. Una selección de Dostoievski, Novela en nueve cartas fue la obra leída cuando se inició este proceso.

Los cambios de estaciones se dieron y las clases iban dejando su huella. Las reuniones con compañeros, momentos realmente gratos y personas maravillosas se fueron volviendo cada vez más familiares. Incluso esa familiaridad excedió las aulas y formó lazos fraternales que se mantienen en la actualidad.

Debates en medio de las temáticas planteadas en cada sesión, me mostraban nuevos escenarios y nuevas conclusiones. Conflictos y cruces epistemológicos me abrían nuevas posturas que volvían a hacerme sentir como el de acento diferente, pero con una invitación a las reconsideraciones. Ya no estaba en mi lugar común que era la psicología, la general, la que uno u otro incauto confunde con el ejercicio clínico, ahora estaba aprendiendo y aprehendiendo de comunicación, la que uno u otro incauto confunde con su ejercicio informativo. Ahora reconozco que las clases y la formación de estos espacios no estaban solo en las aulas de la facultad y que el aprendizaje llegaba incluso a ubicarse en un almuerzo en la costa de Ensenada o con un café apreciando los cerros orientales de mi amada Bogotá.

De vuelta en mi país, después de tres años y con la tarjeta del gestor que había conocido en el viaje, me contacté con él y ahí empezó una maravillosa aproximación a la fiesta popular del Carnavalito por la vida y el amor, un viaje personal lleno de enriquecimiento.

Lo planteado hasta acá busca cuestionar el lugar en que nos ubicamos ante una problemática social. Estamos inmersos en un inmensa trasegar de conflictos sociales y podemos decidir cuál papel asumir: el del británico que ve el conflicto pero no interviene porque no lo entiende; el del profe que conoce y ha vivido las problemáticas que lo afectan pero se enmarca en solo ser el narrador de lo sucedido o también podemos ser un sujeto que activa elementos de transformación en procura de la comunidad.

Lo crucial en esta reflexión es que independiente del papel que tomemos, este papel lo asumimos con todos los contenidos de nuestra experiencia vivida, con nuestro holismo, con nuestra complejidad. Y es entonces cuando me ubico acá, ocho años después de conocer al admirado Fernando Cardona, quien me ha permitido buscar la forma de dar un aporte con mis saberes a los saberes de un territorio con muchas potencialidades. 


\section{Resumen}

En el presente texto se documenta el ejercicio de aproximación a una comunidad del sur de Bogotá, que ha persistido hace ya varios años por una construcción de una identidad positiva para los integrantes de su territorio. Se da cuenta de un acercamiento a líderes comunitarios que han tenido en su trasegar una historia de construcción social y que nos cuentan cuáles son sus proyecciones con su ejercicio insignia llamado El Carnavalito por la vida y el amor; evento llevado a cabo en barrios del sur de la ciudad.

Damos uso a esta aproximación como instrumento para establecer un diagnóstico comunicacional, que será el sustento para elaborar una estrategia de desarrollo comunicacional y en la cual se comprenderán, la situación actual de la comunidad alrededor de la fiesta popular del Carnavalito, su visión de cómo se podría presentar a futuro en un escenario desfavorable y la construcción hacia un escenario de sus deseos como gestores de transformación.

Se tomará lo encontrado en el diagnóstico para hacer uso de la tecnología transformadora de la planificación comunicacional, guiados por la orientación de los esquemas de la Maestría en Planificación y Gestión de Procesos Comunicacionales.

Con esta estructura se propone y ejecuta un proyecto de desarrollo que aporta a las transversalidades de los procesos adelantados en el territorio, teniendo como propósito la formación de jóvenes líderes de la comunidad en competencias como la ciudadanía y la identidad comunitaria. Y, con el avance del proceso, aportar en la construcción de la memoria colectiva.

Palabras claves: Planificación, gestión, comunicación, transformación, audiovisual. 


\section{Tabla de contenidos}

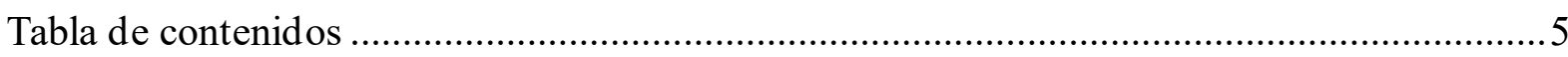

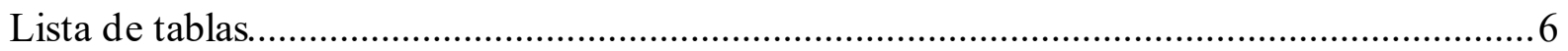

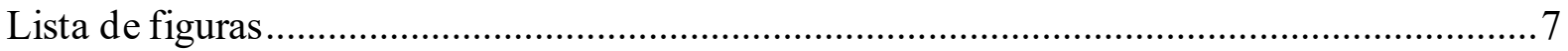

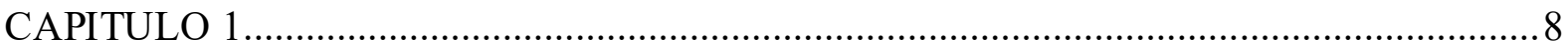

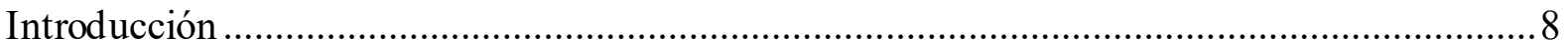

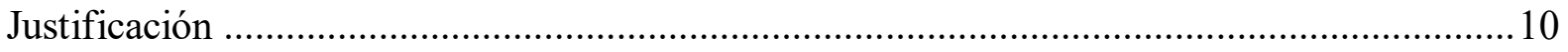

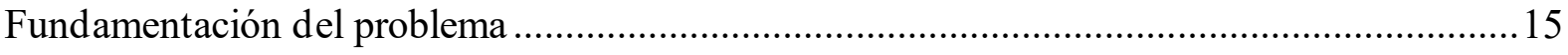

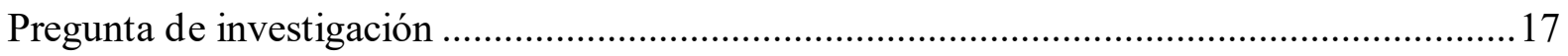

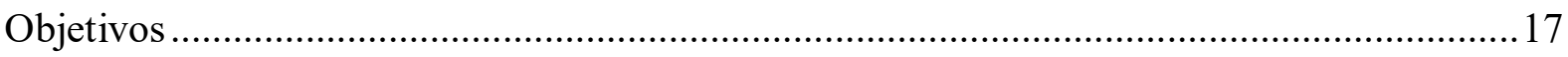

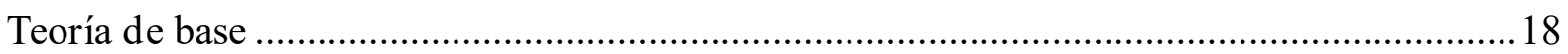

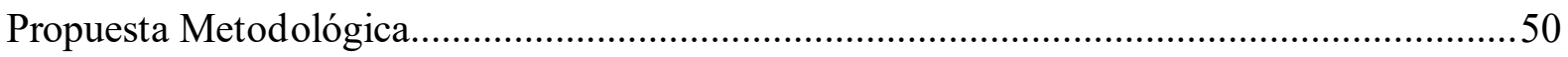

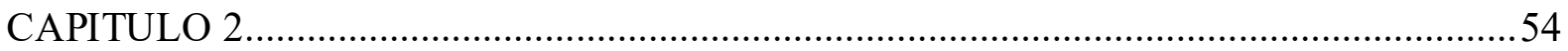

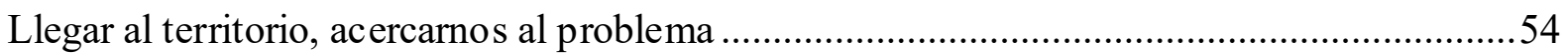

Contexto de la ciudad de Bogotá. Descripción del campo material ......................................56

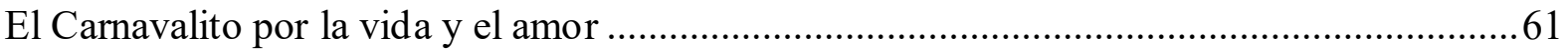

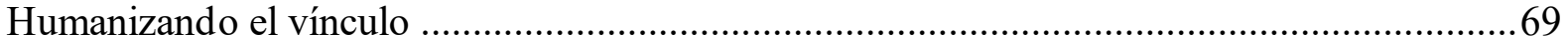

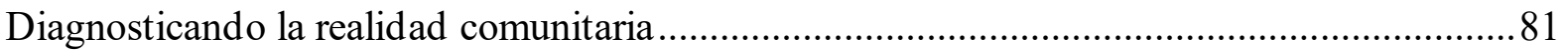

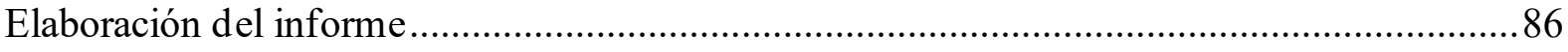

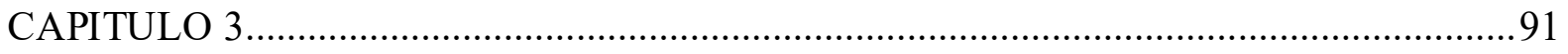

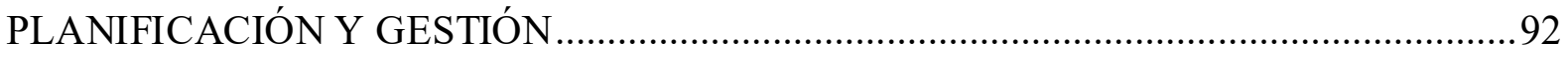

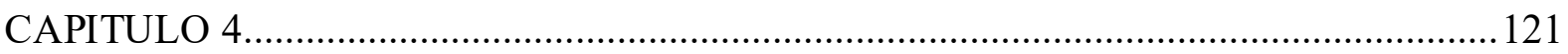

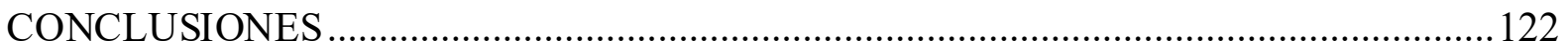

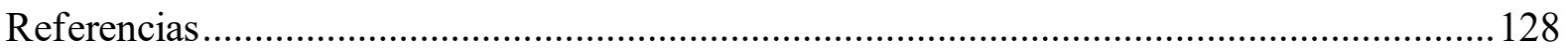




\section{Lista de tablas}

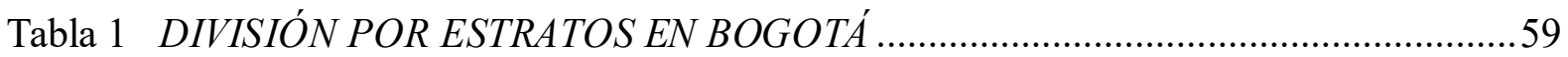

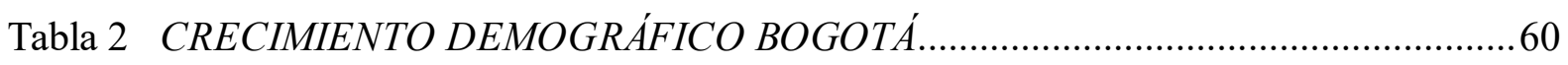

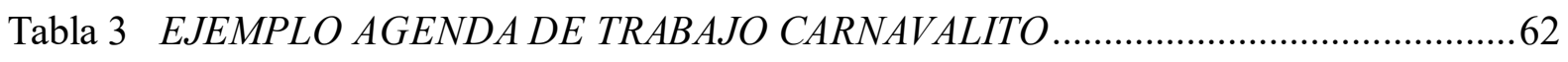

Tabla 4 EJEMPLO CRONOGRAMA DE ACTIVIDADES DEL CARNAVALITO.................66

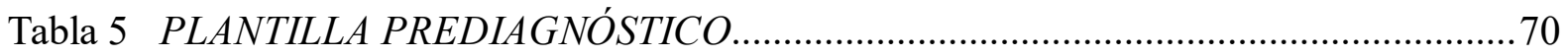

Tabla 10 MATRIZ DE LA ESTRATEGIA DE PROCESOS COMUNICACIONALES............95

Tabla 11 MATRIZ DE REALIDAD MATERIAL Y OBJETIVA ...............................................95

Tabla 12 MATRIZ DE VALORES SUBJETIVOS DE LA COMUNIDAD ..............................96

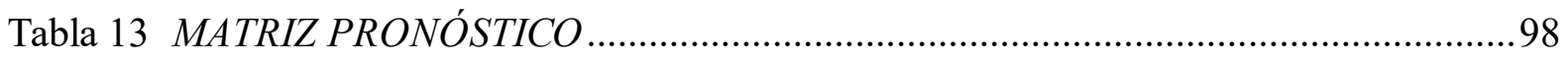

Tabla 14 MATRIZ DE IDENTIFICACIÓN DE ELEMENTOS POTENCIALES DE DESARROLLO / REALIDAD POR INTERVENIR PARA LA TRANSFORMACIÓN ....99

Tabla 15 MATRIZ DE CONSTRUCCIÓN DE OBJETIVO DE DESARROLLO / FUTURO

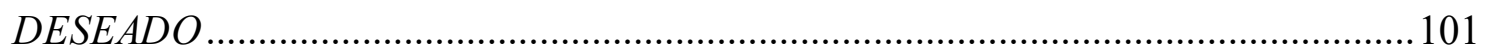

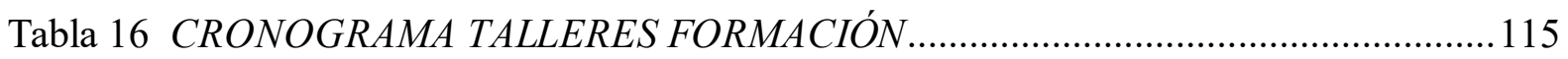

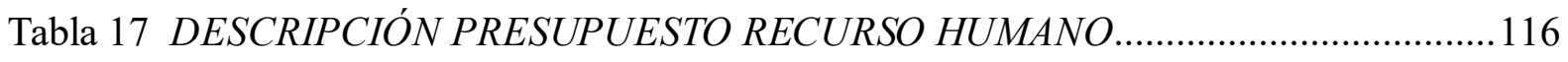

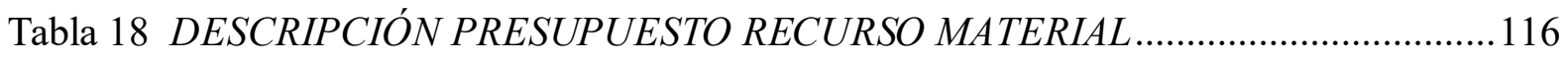

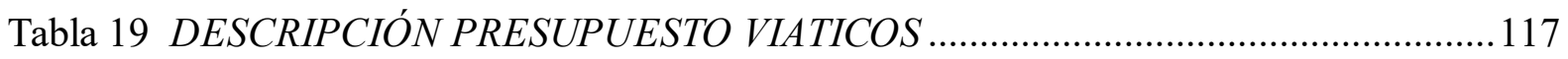

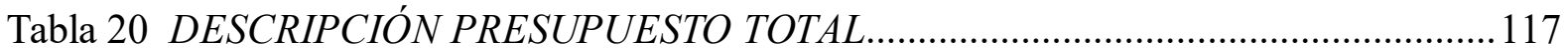

Tabla 21 DESCRIPCIÓN CALENDARIO EROGACIONES ................................................ 117 


\section{Lista de figuras}

Figura 1 PANFLETO DE AMENAZA EMITIDO COMO PREAVISO. 10

Figura 2 RELACIÓN DEL TIPO DE OPERACIÓN DE PODER Y LA DIMENSIÓN DE EMPODERAMIENTO DESARROLLADA .25

Figura 3 LA LOCALIDAD 19, CIUDAD BOLÍVAR A SU VEZ SE DIVIDE EN 8 UPZ .......57

Figura 4 MAPA CIUDAD BOLÍVAR, DIVISIÓN POR SUS 8 UPZ ......................................57

Figura 5 MAPA DE BOGOTÁ DEMARCANDO LAS ZONAS ESTRATIFICADAS ..............58

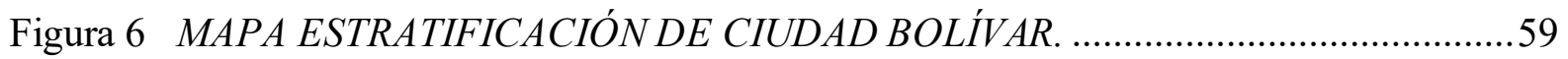

Figura 7 MAPA DE BOGOTÁ, UBICACIÓN DE CIUDAD BOLÍVAR ...............................66

Figura 8 MAPA TOMADO DE PLAN LOGÍSTICO $10^{\circ}$ CARNAVALITO ............................67

Figura 9 GRÁFICA MATRIZ DE ESTRATEGIA DE DESARROLLO ..................................93

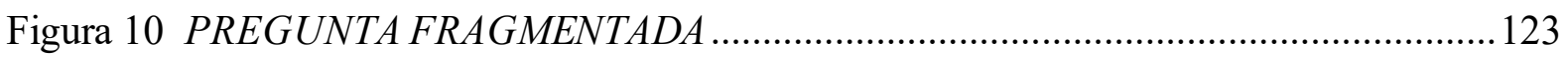

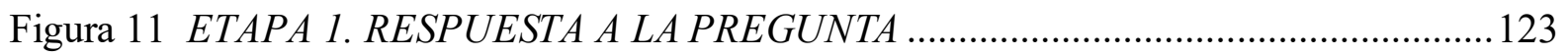

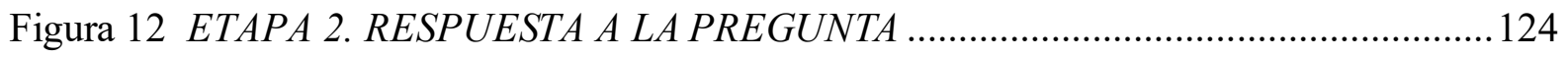

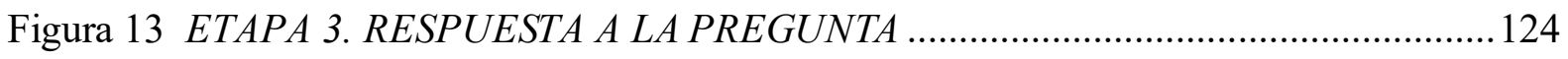

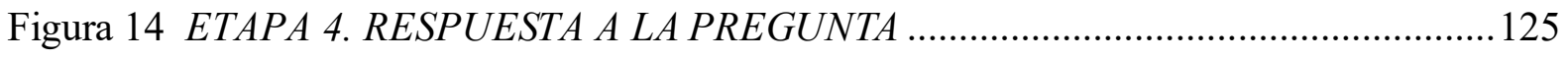




\section{CAPITULO 1}

\section{Mi proceso. Unas comillas aparte}

Llegar al Carnavalito por la vida y el amor fue un aterrizaje de varios intentos. Al comenzar, por el 2015, un contacto con Fernando Cardona, líder comunitario y uno de los fundadores de la corporación de trabajo social INTI TEKOA, quien se volvería el contacto directo con la comunidad, me daría las coordenadas para encontrar un lugar que en principio miré con ojos de investigador académico y concreto. Abordé el territorio desde mis archivos personales y la consulta en bibliografía acerca de la zona en donde se realizaba el Carnavalito. Me hice un trazado mental acerca de los aspectos que se debían evaluar y de cuál sería la naturaleza de los datos más adecuada para mi aproximación. Fue cuando decidí tomar registros del evento en su presentación de caravana; registraba mientras organizaba los componentes técnicos que iban a estructurar la investigación. Sin contar con un tema en específico, me dispuse a aproximarme al territorio para construir más adecuadamente las herramientas con las que tomaría mis medidas.

Pero, las invitaciones a participar de espacios cotidianos y de reuniones de la comunidad, me hicieron replantearme la concepción de aproximación investigativa con la que inicié mi observación. “¿Debía tener al dato y la medida como eje principal de mi mirada?”, la respuesta después de varias consultas fue no.

... uno coge un taxi y le dicen 'uy, no, Ciudad Bolívar', no, yo si les digo 'camine y les muestro mi barrio, que no es como usted lo pintan'. Entonces, yo sí me siento orgullosa de vivir en Ciudad Bolívar. Entrevista a Flor Alba Herrera (Herrera, 2016), lideresa de las madres comunitarias.

De nada nos sirve llegar con estadísticas y líneas de tendencia en gráficas si no se entiende el deseo de los actores de la comunidad. El mirar la emocionalidad y la cotidianidad de la charla de los gestores del Carnavalito despliega el deseo de cambio que quieren para su comunidad y es justo ahí de donde se toma el enfoque guía de esta aproximación.

\section{Introducción}

Al sur de la ciudad de Bogotá, en una de las zonas conocidas como los cinturones de la ciudad $^{1}$, un conjunto de organizaciones sociales ${ }^{2}$ se reunió para expresar su inconformidad

\footnotetext{
${ }^{1}$ Los cinturones de ciudad son como se conocen a los terrenos de las periferias más a lejadas de la ciudad central, a demás de esto, estas zonas suelen ser de difícil acceso y de condiciones que dificultan el desarrollo de
} 
por la presencia de asesinatos selectivos (en especial la de jóvenes habitantes del sector) y para suplir la necesidad de cambiar los imaginarios negativos de la localidad y a su vez fomentar la apropiación del territorio por la comunidad.

Estos asesinatos selectivos son una realidad de la república de Colombia, incluso desde que era una más de las colonias españolas. Los asesinatos selectivos suelen dejar como producto de este acto delictivo los cadáveres de sus víctimas. Estos cadáveres son usados por los grupos armados como advertencia para las personas que no encajen en sus perfiles de aprobación y por tanto se vuelven objetivo para atacar. Generando de esta forma atmosferas intimidatorias para las comunidades.

Hacia finales del siglo XX e inicios del XXI a estos asesinatos selectivos se les empieza a conocer comúnmente con el denominativo de 'Limpieza Social'. En ocasiones los grupos ${ }^{3}$ responsables de estos actos pueden emitir sus comunicados a través de panfletos ${ }^{4} \mathrm{de}$ amenazas generales, pueden amenazar directamente o simplemente asesinar sin previo aviso.

Un conjunto de organizaciones comunitarias ${ }^{5}$ de algunos de los barrios afectados por estas situaciones, al sur de Bogotá, se ideó una forma de oponerse y expresarse en contra de este tipo de acto Intimidatorio para la comunidad, es entonces cuando surge El Carnavalito por la vida y el amor, una manifestación popular en forma de caravana en la que marchan las personas convocadas y aquellas que espontáneamente se quieran vincular a él.

Esta tesis tiene como propósito aproximarse a esta manifestación popular y aportar al fomento de la significación, en busca del sentido, de estas experiencias comunitarias por medio de la participación en espacios dispuestos para la transformación social, con diálogos e intercambio de saberes, teniendo el uso de herramientas audiovisuales como punto de partida.

Parte del objetivo de esta aproximación es reconocer los diferentes puntos de vista que pueda tener cada uno de los gestores que son parte de esta iniciativa y de esta forma trabajar de la mejor manera las acciones que se propongan para la comunidad a modo de líneas de acción.

la calidad de vida de los que las habiten, comparadas con los espacios de ciudad con terrenos más a mables y que son parte de la propiedad de otros grupos sociales.

${ }^{2}$ Asociaciones de jardines de madres comunitarias y Corpora ción de trabajo social Inti Tekoa.

${ }^{3}$ Son grupos al margen de la ley que pueden ser parte del brazo armado delEstado o creación de pobla dores del sector que justifican su actividad en la búsqueda de la "seguridad" de la zona .

${ }^{4}$ Los panfletos no son los únicos formatos de amenaza de muerte por parte de los grupos armados. Acá un ejemplo de una amenaza telefónica: AMENAZA PARAMILITAR EN COLOMBIA - DEYANIRA BALLESTAS. https:/www.youtube.com/watch?v=-JexGbeeEO4

${ }^{5}$ Las organizaciones comunitarias fundadoras de iniciativas como El Carnava lito por la vida y el amor, son Las Madres Comunitarias del barrio Caracolí del sur de Bogotá y la Fundación INTI TEKOA. 


\section{Figura 1}

PANFLETO DE AMENAZA EMITIDO COMO PREAVISO.

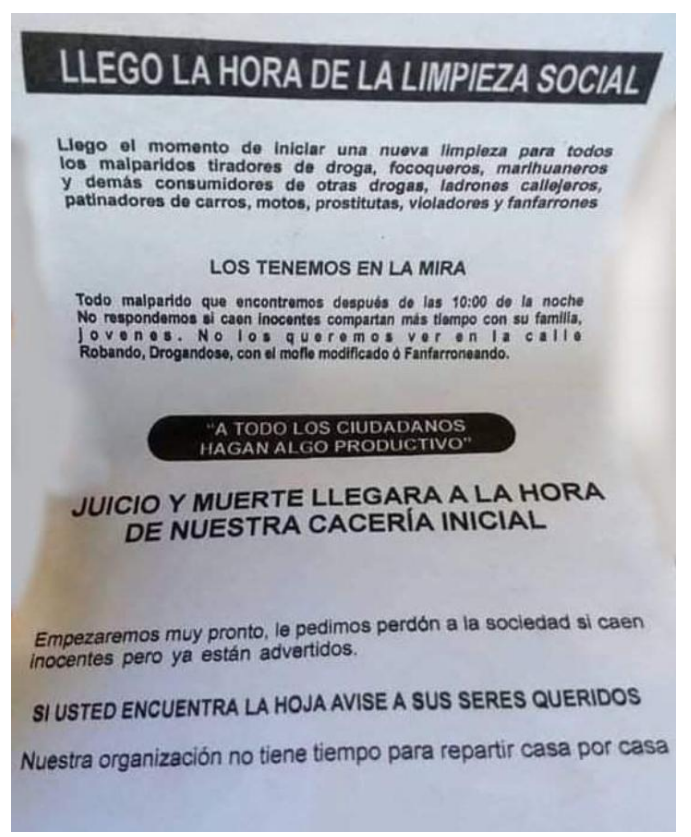

(Bustos, 2013).

\section{Justificación}

El espacio territorial del que es parte El Carnavalito por la vida y el amor, es una herencia de esfuerzos de varios líderes que han aportado más que solo voluntad en la búsqueda de mejorar las condiciones de vida de la población que habita los barrios de la localidad de Ciudad Bolívar, al sur de Bogotá. Una población que procura mejorar su calidad de vida desde lo más esencial que es el empoderamiento de ellos mismos, de ellos en su territorio y de ellos en su comunidad.

Me propuse aproximarme a la comunidad alrededor del Carnavalito, participand o y registrando durante varios años sus dinámicas alrededor de la planeación y ejecución de la manifestación cultural, llegando de esta manera a recorrer y conocer el territorio, entendiendo que de esta forma se podría aportar al crecimiento comunitario y con esto fortalecer la tarea que hacen los líderes y la comunidad misma.

Mi participación inicial como espectador fue evolucionando hasta ser parte de la producción del mismo Carnavalito, hablando con participantes, organizadores y con aquellos que incluso desconocen el evento mismo, aun estando en el territorio y observando las manifestaciones de éste.

Fue de esta manera que pude escuchar muchas de las voces, que de no ser por esta actividad de inmersión no habría podido conocer. Su fuerza y deseo de mejorar las 
condiciones de su comunidad, su voluntad para cambiar los discursos y sentidos que circulan en su territorio, que muchas veces se ven truncados por la falta de espacios de desarrollo, han hecho que a pesar de las falencias continúen aprehendiend o de sus propias experiencias y del intercambio de saberes gestado por las mismas acciones de sus esfuerzos.

Ante esto, el aporte de la mirada de la maestría PLANGESCO me ha dado un complemento desde el sustento de la academia esa realidad comunitaria, ya que enseña a intervenir poniendo cauces para construir sentidos, aportar pensamiento estratégico, político y complejo a través de la planificación endógena y participativa para transformar positivamente los problemas y flagelos que sufren las comunidades más vulnerables. Esto, buscando el reconocimiento de esos saberes emergentes de la comunidad para potencializarlos y generar escenarios para el diálogo de las subjetividades.

Mi compromiso como comunicador planificador para la transformación, ha sido realizar aportes poniendo saberes en diálogo, realizando estrategias desde, con y para la comunidad, sin cruzar esa frontera del asistencialismo que considera al otro como desvalido y no como un agente en potencia, un gestor de su propio cambio, y considerar que también este aporte signifique una transformación de mí mismo como un crecimiento recíproco.

La comunidad como subjetivación social, genera un intercambio de saberes y experiencias para todo el que interactúe con ella y es por tanto esperado y buscado que se dé un proceso de crecimiento de los participantes, impulsado este crecimiento por el buen camino y la transformación de las acciones llevadas a cabo en el territorio.

Las contribuciones del aporte del Carnavalito han hecho que se empiece a repensar el territorio desde el mismo territorio, ha hecho que se reescriba la concepción misma de sus realidades, ha hecho que se aprecie la forma misma de su historia. La ganancia en arraigo y apropiación de parte de los integrantes de la comunidad matiza con nuevos tonos lo esperado para estas y las nuevas generaciones. Hace que se vislumbren mejores prospectos dentro de lo social, edificando los aportes sobre lo que ya se ha hecho. Se ha dado una esperanza que aviva la búsqueda de utopías. Pero al igual que se han reconocido las bondades de la ejecución del ejercicio del Carnavalito, se tienen que reconocer los riesgos de la pérdida del mismo; esto se ha observado en el desarrollo a través del tiempo donde se han enfrentado en diferentes debates a diferentes voces acerca del camino a seguir. Los desacuerdos, apenas esperados en cualquier grupo humano, hacen pensar que se pudiese caer en el olvido cada una de esas actividades que han materializado los deseos de la comunidad. La posible pérdida de tanto esfuerzo causada por la ausencia del combustible de la motivación, hace necesario que se piensen nuevos escenarios, nuevas actividades, nuevas formas de seguir construyendo 
comunidad, pero para esta tarea se tiene que conocer y participar de las realidades pensándolas como espacios de transformación.

Una transformación, entendiéndola como la forma de fortalecer el acto participativo de los sujetos comunitarios de estos barrios del sur de la ciudad, que incluya los mensajes del mismo territorio en el entramado de sentidos, que genere y procure una identidad propia, forjando una atmósfera de crecimiento desde los cimientos trabajados por la comunidad de la localidad, creando sujetos políticos que sean críticos con sus realidades y que participen del cambio de estas.

\section{El accionar político del Carnavalito por la vida y el amor}

Todo acto humano es un acto político, incluso la desidia y el desinterés son unas posturas que tienen repercusiones en las estructuras y dinámicas de las sociedades humanas. Esto implica que cualquier intervención en el campo de lo social necesita ser pensad a desde una dimensión política, ya que de no ser así se omitirán variables que determinan los flujos de estos campos sociales.

Es, por tanto, necesario que se entienda el campo social como un espacio donde las posturas, discursos, deseos, frustraciones y demás mecánicas del potencial humano confluyen para condensarse en sustentos, en ocasiones inmateriales, pero muy reales, en donde se edifican las comunidades. Es, justamente, ese intercambio de saberes donde se conciben las dinámicas políticas, las relaciones de poder y el debate por la construcción de las realidades, esto a grandes rasgos es lo que entendemos como política, no el acto burocrático de las instancias de instituciones en el poder de las naciones.

Aclarado lo anterior, concebimos a todo cambio o propósito de cambio de esas dinámicas sociales como un acto político y, por tanto, todos los sujetos partícipes de esos intercambios son actores políticos activos de realidades en las que se encuentran inmersos.

La comunidad de las UPZ 69 y 70 de Ciudad Bolívar, al sur de Bogotá, es una inmensa representación de un campo social nutrido por la confluencia de actores de diferentes condiciones personales, experiencias y grupos sociales, por décadas de migraciones por la violencia del interior del país y por la violencia económica que ha edificado barriadas de asentamientos de familias completas, pero que con los años se han vuelto parte del registro mismo de la ciudad.

En el ejercicio llevado a cabo en la comunidad alrededor del Carnavalito se remarca la postura del cambio social como directiva del proceso. El empoderamiento de los habitantes 
del territorio, el cambio en los discursos y en los sentidos es donde se ha tomado fuerza y mayor enfoque en cada intervención comunitaria.

Sostendremos que en estas prácticas el sujeto comunicador debe tener una motivación política como resultado del compromiso por formar parte de prácticas y procesos sociales de transformación de la realidad aportando clarificación y reflexividad a las posiciones asumidas por los actores y a los sentidos que circulan en torno a esos procesos. (Venier, 2014, pág. 31).

Es claro que las condiciones de los barrios de las periferias del sur de Bogotá se revisten de realidades propias que implican acciones particulares, ya que las actuales estructuras sociales y económicas enmarcan claras condiciones impuestas de vulnerabilidad en líneas esenciales para el desarrollo de la comunidad. Aunque es evidente esta vulnerabilidad lo que en ocasiones no es tan evidente para algunos es que hay dispositivos de poder que sostienen esas condiciones estructurales donde se refuerzan discursos y prácticas que se vuelven parte de las realidades de los mismos habitantes de estos sectores. La supuesta incapacidad de la autogestión, la conflictividad como parte de sus condiciones socioeconómicas, las limitaciones para concebir y generar condiciones futuras, son parte de esos sentidos y representaciones impuestos que buscan definir a priori el acto de los habitantes del territorio. Estas imposiciones han calado en muchas de las voluntades encontradas en estas colectividades y la repercusión de esto es que se coactan las fuerzas de los sujetos y se observa un desinterés por las iniciativas que les dicen que el cambio puede venir de ellos mismo sin la necesidad del asistencialismo de instituciones foráneas.

Mostrar en acto que el Carnavalito surge de la gestión propia de la comunidad, de su pensamiento endógeno, demarca positivamente que esas imposiciones se pueden romper y esto es un acto político, como acto de liberación y transformación. Es democratizar las decisiones sobre su comunidad, es darles la potestad del ejercicio de la opinión y la decisión.

\section{Comunicación, medios de comunicación y desarrollo}

"Desde la comunicación, un medio ciudadano es catalizad or de procesos de apropiación simbólica, procesos de re-codificación del entorno, de re-codificación del propio ser, es decir, procesos de constitución de identidades fuertemente arraigadas en lo local, desde donde proponer visiones de futuro." (Rodriguez, 2013, pág. 100).

Conocer una comunidad, entenderla, vivirla y reconocerla, no se puede decir que sean ejercicios que se puedan realizar con un puente distinto al comunicacional. Las asociaciones de personas, así estas se den espontáneamente, necesitan compartir códigos mínimos para 
poder interactuar. La comunicación vincula y sin ella nos separaríamos como en el mito de la torre de babel ${ }^{6}$. Es por esto, que es de vital importancia, reconocer estos puentes y con ellos poder generar una estrategia que beneficie a la comunidad y que la potencie.

Una buena forma para lograr una mediación a largo plazo es anticiparse a los posibles escenarios que se puedan dar en los espacios trabajados. Para esto se tiene que contar con una gran experticia en estas áreas y una atinada recursividad en los dispositivos de análisis con los que se pueda intervenir. En relación a la vinculación social de nuestros tiempos se puede decir que la tendencia se da, desde hace décadas, hacia una tecnificación de las interacciones. Esto es una verdad que se observa en la cantidad de las ya mencionadas interacciones que cada humano tiene con sus dispositivos tecnológicos, que utilizan para comunicarse; se ve en el mercado global, que mueve billones de dólares, en la producción de aparatos de comunicación como celulares, tablets, computadores y demás dispositivos; se ve en el posicionamiento de las empresas que manejan los contenidos que se mueven a través de las redes y se ve en el poder de las empresas que proveen esas conexiones y administran los datos que por ellas se mueven. Acerca de esto Marshall McLuhan nos dice:

Los medios de comunicación del futuro acentuarán las extensiones de nuestros sistemas nerviosos, los cuales pueden ser separados del cuerpo y ser convertidos en colectivos. Las nuevas normas poblacionales alimentarán el cambio de las industrias de chimenea a la economía con información de marketing, en particular en los Estados Unidos y Europa. Las tecnologías relacionadas con el vídeo son los instrumentos críticos de dicho cambio... Por ejemplo, la nueva corporación de telecomunicaciones multiportadora, dedicada sólo a mover todo tipo de información a la velocidad de la luz, generará de manera continua productos y servicios hechos a medida para consumidores individuales que señalaron sus preferencias con anterioridad a través de una base de datos continua. Los usuarios se convertirán en productores y consumidores en forma simultánea. (McLuhan \& Powers, 1995, pág. 90).

Se puede pensar que gracias a este tipo de hiperconectividad el planeta tierra se volvió un gran cerebro que tiene a cada humano conectado a modo de neurona y que cada grupo social puede ser la analogía de los nodos y conexiones específicas para un tema en particular. Pero, el cuidado que se debe tener es que este es un cerebro sin humano, sin ánima, sin consciencia, una conectividad sin moralidad sobre un tejido natural como es el planeta Tierra,

\footnotetext{
${ }^{6}$ Mito encontrado en el Genesis 11 1-9, donde el señor Yahvéh impide que se termine de construir una edifica ción que tenía como propósito llegar al cielo, cambiándole el idioma a sus constructores, confundiéndolos y logrando que en su imposibilidad de hacerse entender abandonaran el proyecto y se dispersaran por el mundo.
} 
que con su propia existencia sufre de esa máquina que se ha vuelto la sociedad humana. Es acá donde se tiene que hacer énfasis ya que de lo que circule en esa red depende de lo que nos depare el futuro, no solo como especie sino de lo que eso implique, pues también es una realidad que la flora, la fauna y en esencia el planeta mismo, tienen la carga de los movimientos humanos. Privilegio que no ha sido bien llevado por el hombre.

Continuando con la analogía, la comunidad alrededor del Carnavalito sería un nodo neuronal de interrelaciones que trata de establecer una apropiación del territorio y un rechazo a la violencia, para preservar su sanidad, integralidad y estabilidad en el entramado social.

Aunque, sumado a lo anterior, considero que a las tecnologías no se les debe satanizar, sino muy al contrario se debe buscar que sean parte de la cotidianidad, pero de una manera saludable. De manera que sea la comunidad la que controle la tecnología y no a la inversa. Entonces, debemos aproximarnos estratégicamente para hacer útil a la comunidad esta herramienta global, con todos los esfuerzos encaminados al crecimiento y desarrollo humano como formador del ciudadano del mundo y como responsable del cuidado de este último.

\section{Fundamentación del problema}

El abandono estatal en los territorios de Colombia ha ocasionado una atmósfera de anarquismo en donde el más fuerte se impone, dejando a los débiles a la merced de las circunstancias. Para dolor de nuestro país, estos "fuertes" son grupos organizados con métodos extremadamente nocivos para la construcción de cualquier sociedad sana. Esto se puede ver en lo que se ha presentado desde que se nos considera una república, en los territorios de nuestros campesinos ${ }^{7}$, en los territorios alejados de las grandes urbes ${ }^{8}$, en el abuso de aquellos a quienes se les confía nuestra propia seguridad 91011 , en el trato que se le da a la ciudadanía en las grandes catástrofes ${ }^{12}{ }^{13}$, en los ciudadanos de mayor posición socioeconómica que pretenden estar por encima de la ley ${ }^{14}$, en el trato a nuestros pueblos

\footnotetext{
${ }^{7}$ Quiebra de la economía campesina por privilegiar mercados internacionales (Revista Dinero, 2017).

${ }^{8}$ Masa cres de grupos armados almargen de la ley (Neira, 2002).

${ }_{9}^{9}$ Masacre de grupos paramilitares respalda das por el ejército nacional (Guarnizo, 2015).

${ }^{10}$ Asesinato de civiles por parte del estado para disfrazarlos y presentarlos como bajas (a sesinatos) a miembros de grupos armados ilega les (Agencia EFE, 2019).

${ }_{11}$ Asesinato de civiles menores de edad por policías en funciones y encubiertos por la misma entidad (Revista Semana, 2017)

12 El estado desa parece personas y entorpece las investigaciones que se adelantan para aclarar los hechos (Marín, 2017).

${ }^{13}$ La espalda del estado a la prevención de catástrofes naturales como la que sepultó a 22.000 personas (Gallo, 2017).

${ }^{14}$ Los más ricos del país gozan de tratos especiales por la ley (Pulzo, 2019).
} 
originarios $^{15}$, en cómo se revictimiza a los que ya han sufrido el rigor de estos grupos armados ${ }^{16}$ por funcionarios sin competencia pero con poder ${ }^{17}$, en unas condiciones generadas por el establecimiento Estatal ${ }^{18}$ y negadas por el mismo ${ }^{19}$, en eso y en otros escenarios de la cotidianidad colombiana.

El Carnavalito es una voz que se alza contra esa opresión de la violencia, tanto la directa como la simbólica o estructural, que para muchos es invisible, o que dicho más fríamente, es una opresión invisibilizada, es una voz que viene a darle cuerpo a esos deseos de la población que en el sur de Bogotá adolece de privilegios estatales, que muchas veces se dice que llegarán pero que nunca lo hacen. Por esta razón, los esfuerzos invertidos en estas iniciativas son siempre bien recibidos. La demostración de una fuerza autoconcebida y autogenerada, como lo es esta del Carnavalito, busca despertar intereses de integrantes de la misma comunidad, que muchas veces forman parte de una pasividad que les fue instruida por las circunstancias y esas experiencias que en muchas formas se puede decir que son impuestas. Este proyecto ha buscado contar con elementos que interpreten de la mejor manera el deseo de la comunidad.

Al irrumpir esa pasividad, el Carnavalito rompe esa entropía subjetiva que proyecta los saberes y opiniones hacia el interior de cada persona, reprimiendo la generación de un entramado comunicacional y, por implicación de este último, del entramado social. Con el escenario del Carnavalito se busca posibilitar una comunicación entre pares, un ir al otro, y de esta forma potencializar la capacidad transformadora.

Es entonces cuando entendemos que, ya que las sociedades humanas no son estáticas, incluyendo la comunidad de los barrios donde se celebra el Carnavalito, la adaptación de los procesos desarrollados en y por estas sociedades a las épocas en donde se presentan, deben contar con ajustes a estos cambios de tiempos, espacios y usuarios de estas dinámicas y de esta forma generar nuevos escenarios para el intercambio y desarrollo de las actividades comunitarias, al igual que una oportunidad para los usuarios de actualizar los procesos, buscando que estos no se tornen obsoletos para el beneficio comunitario. Es por esto que la

\footnotetext{
${ }^{15}$ Desinterés por la seguridad y resguardar la vida de los integrantes de las comunidades indígenas (Telesur, 2019).

${ }^{16}$ Una víctima de despojo de sus tierras por grupos armados es a menazada por un juez que la acusa de mentir para desviar sus declaraciones (Noticias Uno, 2019).

${ }^{17}$ El juez que amenazó a víctima de desplazamiento y despojo, no cumple con las competencias mínimas exigidas para ejercer su cargo y a pesar de eso ejerce como juez de la república (Noticias Uno, 2019).

${ }_{18}$ Desempleo genera lizado por las incorrectas estrategias estatales para mitigar la desocupación laboral (Barbosa, 2019).

${ }^{19}$ Negación por parte de funcionarios oficia les de la rama de poder ejecutivo colombiano de su responsabilida d por policías ejercidas por ellos (Pulzo, 2019).
} 
invitación de esta tesis ha sido reconocer el excelente trabajo de la propuesta del Carnavalito en la actualidad y estimar hacia a dónde se puede proyectar, y, cómo este puede llegar a ser el pilar en donde se reconozcan otros procesos tales como la identidad y el empoderamiento de las intersubjetividades, todo esto bajo la guía de sus promotores.

Por esta razón se empieza a identificar la intervención comunicacional, al reconocer los puntos de vista particulares y congregándolos para definir el encuentro de las perspectivas, que servirán como la meta hacia donde se orientará el Carnavalito.

Es una necesidad que consideremos el hecho de que para preservar iniciativas colectivas, como la del Carnavalito, estas deben entenderse en un marco en el que se trascienda el impacto del corto plazo y concebir que en escenarios futuros la falta de inclusión de la comunidad en general pueda conllevar a un eventual deterioro del ejercicio comunitario.

\section{Pregunta de investigación}

¿Se puede desde una estrategia comunicacional fomentar la significación del Carnavalito, por medio de las dinámicas de los gestores e integrantes de la comunidad, tales como espacios de formación e inclusión, para la creación de una memoria audiovisual que contribuya a la formación de procesos comunitarios, como el fomento de la integración y la identidad del territorio?

El entorno en el que se establece esta pregunta, es uno en el que se tiene como meta el beneficio comunitario, procurando dejar un esquema que forme a la misma comunidad, a modo de una escuela que vaya entregando la toma de conciencia de grupo a los que vayan aproximándose al mismo.

Es entonces entendible que los actores principales sean los gestores e integrantes de la comunidad, ya que son el principio activo de esas relaciones y actividades a las que nos referimos como dinámicas comunitarias.

\section{Objetivos}

\section{General}

Reconocer y dinamizar los procesos comunicacionales de la comunidad alrededor del Carnavalito, para fomentar la significación de las experiencias que posibiliten narrativas de una memoria cultural de la comunidad, por medio de la implementación de técnicas y herramientas de intercambio de saberes y comunicación audiovisual. 


\section{Específicos}

Identificar las expectativas de los grupos partícipes en la gestión del Carnavalito, para visibilizar los contenidos y proyecciones en relación a este a través de entrevistas semiestructuradas y acción participativa.

Contribuir a la formación de la identidad comunitaria a través de procesos reflexivos de reconocimiento.

Formar a los líderes que participan de esta iniciativa en el uso de herramientas de registro y producción para generar contenidos que enriquezcan su memoria institucional.

Posibilitar el autorreconocimiento en el proceso de sistematización de los eventos comunitarios con los líderes y participantes de estas iniciativas.

\section{Teoría de base}

Aproximarse a cualquier espacio de interés es mucho más enriquecedor cuando se cuenta con voces que inviten a la suma de posturas y que ayuden a aclarar dudas y motiven a crear puentes entre los diferentes posicionamientos. Es por eso que además de incluir a los actores directos de los territorios, debemos contar con las experiencias de los diferentes autores que al realizar sus ejercicios han definido conceptos que ayudan a dar una más precisa aproximación en la descripción de los interventores, que usan esos aportes para nutrirse.

Entendiendo que, en forma de apoyo para la aproximación a la comunidad alrededor del Carnavalito, se pueden encontrar aportes en textos que den luz a sus procesos, es que vamos a tomar este capítulo para hacer un recuento de conceptos que enmarquen lo expuesto en esta tesis. Hemos partido de un planteamiento que habla de disciplinas como la psicología y la comunicación para después tomar conceptos transversales con una marcada pertinencia para los propósitos de nuestra aproximación e intervención.

Siendo así, podemos empezar con una contextualización general para vislumbrar todo el panorama acá enmarcado.

Empezamos viendo que la búsqueda de respuestas a las inquietudes que ha tenido la humanidad, ha llevado a aproximaciones tímidas en algunos casos y osadas en algunos otros. Pero en ese vaivén de la curiosidad el humano ha ido segmentando lo que, al parecer del mismo humano, son unidades de conocimiento bien definidas, estoy hablando de las ciencias y las disciplinas. Es así que en la actualidad la biología, la química, la farmacéutica, la botánica, entre muchas otras, son unos cuerpos de conocimiento que en los tiempos actuales se encuentran en un bloqueo, en comparación del crecimiento exponencial que se tuvo en 
otros momentos. Pero, este freno no es por falta de capacidad de los investigadores ni por falta de espacio en los calendarios académicos, o por falta de inversión. Es porque se puede haber llegado a un embudo de la aproximación al conocimiento del objeto de estudio. Al pretender en estas disciplinas que se pueden tener sistemas radicalmente cerrados se está negando la conexión que tiene todo lo contenido en el universo. Apoyo lo anterior en la teoría general de los sistemas (Bertalanffy, 1989) que reconoce que se pueden tener dos clases de sistemas, dentro de los que se estudian: los sistemas cerrados y los sistemas abiertos. Aunque, esto se debe leer con cuidado, pues en ningún momento se afirma que uno sea completamente abierto y el otro sea completamente cerrado. Lo anterior para entender que siempre se va a tener un contacto con agentes externos al sistema y que estos pueden repercutir en las dinámicas propias del mismo sistema. El no aceptar esto solo genera el desconocimiento de factores que puedan ser determinantes a la hora de estudiar algún fenómeno.

Ahora bien, las actividades comunitarias tienen el privilegio de ser una gran fuente de conocimiento que muchas veces es observada desde esos lugares estáticos que pueden ignorar la riqueza del territorio, negando u omitiendo que son un sistema que, aunque se interrelaciona con otros sistemas, puede ser delimitado para buscar una aproximación al conocimiento del mismo. El reconocer lo holístico de la comunidad abre el espectro de observación y de intervención, incluyendo, a los mismos integrantes de la comunidad, que, en otros casos, como los de las ciencias tradicionales, son meros observadores. Con esto se abren muchas posibilidades de mejoras para los procesos, priorizando los beneficios para la comunidad misma.

En el caso de esta tesis, he de explicar que las aproximaciones a la comunalidad de las sociedades humanas también han caído, en muchos casos, en el error de la monoobservación. Una visión desde un solo pilar hace que se pierda el horizonte de visiones de todo lo que nos puede decir de eso observado, de eso interactuado, de eso vivido. Entendiendo que la riqueza de las vivencias, que de esta realidad podamos obtener, nos brindará una mejor calidad en el aporte que podamos regresar a nuestras realidades comunales. Término con el que agrupamos a las vivencias, experiencias, deseos y demás procesos de sujetos con los que se interactúa en el espacio de la investigación. Mal proceso se haría si estimamos que los fenómenos humanos sólo tienen una línea de actividad, que justo encaja con una disciplina de conocimiento, que justamente desarrollamos los humanos. Somos holísticos, como lo es el universo.

Aunque, con cuidado, tampoco se tiene que caer en el error de no entrar a definir las fronteras de nuestros intereses y de nuestros alcances, pues no llegaríamos a ningún puerto 
que quisiéramos alcanzar si pensamos en obtener el conocimiento del universo mismo. Es por esta razón que se debe tener una definición de lo que queremos estudiar, sin caer en el error de hacer una negación y no reconocer la posible intervención de otras estructuras ajenas a nuestros intereses o a nuestros entendimientos.

En ese desarrollo de las sociedades humanas, en su humanidad, se debe entender que por más adhesión que tengamos los sujetos hacia el grupo en el que nos encontremos, también somos personas que contamos con una singularidad. El desarrollo experiencial de esta persona es particular y por tanto único en relación a las otras personas que habiten o hayan habitado esta tierra. Por tanto, considero que uno de los cuerpos de conocimiento que oportunamente puede aproximarse a atender las potencias del individuo es la psicología; entre otras cosas porque no hay una psicología sino muchas. El término psicología es el techo que da sombra a muchas disciplinas que utilizan el mismo nombre pero que no se reconocen como iguales. No entraré en detalles acerca de las diferentes escuelas de la psicología, pero quiero mencionar algunas escuelas entre las que hay mucha diferencia en cuanto a su objeto de estudio, su epistemología y su metodología, es el caso de la psicología conductista, la cognitivista, la neuropsicología y el psicoanálisis, que cuentan con desarrollo a nivel mundial y a todas se les encuentra cuando se habla de la psicología, aunque no son lo mismo.

Pero, no habría coherencia con lo dicho antes si solo tenemos a lo psicológico como lente para observar al mundo. Ya que reconocemos que lo social está conformado por sujetos, también reconocemos que estos en su aislamiento son necesarios, pero no suficientes para crear lo social, ósea, la particularidad de cada persona es necesaria, pero se tiene que trascender esa individualidad para encontrar las sociedades. El propio desarrollo del sujeto necesita de un otro que haga la vez de orientador. Es acá donde vemos que los estudios de comunicación encajan perfecto con la tarea de estudiar esa conectividad entre sujetos y de la cual podemos decir que se observa la primera línea de lo que podemos llamar lo social.

Con lo anterior ya podemos llegar a tocar el territorio. Aquel lugar dond e habitan los integrantes de los diferentes grupos sociales y sus interacciones, que son el interés de esta tesis y que en su voluntad y constancia han hecho realidad lo que a veces para muchos de nosotros no pasa del solo deseo. Son sujetos que en su singularidad han desarrollado un compromiso con la comunidad y que en su sinergia producen el evento cultural y educativo denominado El Carnavalito por la vida y el amor. Evento que, sin lugar a dudas, impacta de manera positiva la cotidianidad que se pueda tener en esta comunidad del sur de la ciudad de Bogotá. 


\section{La psicología y la comunidad}

Uno de los axiomas de la psicología es que esta tiene espacio de intervención en cualquier lugar donde haya humanos, incluso hay métodos psicológicos que nos ayudan con la intervención en otras especies. No obstante, el detalle de la pertinencia de la psicología en el campo de las relaciones sociales cuenta con unas especificaciones más definidas y esto lo podemos ver en disciplinas psicológicas como la de la Psicología Comunitaria. Ésta, presta su interés en el objeto de estudio del desarrollo humano en sociedad, y de los procesos que esta sociedad derive. Procesos que necesitan ser estudiados para que se puedan fomentar, corregir o simplemente se puedan conocer; tod o esto a través de un evaluador/interventor que se adentra en la comunidad para involucrar su propia humanidad y naturaleza con la transformación comunitaria. Intervención en la que prima el beneficio comunitario sobre el beneficio científico. Es por esto que estos intereses ontológicos y epistemológicos aportan de manera enfática a los propósitos de este trabajo. Maritza Montero (Montero, Hacer para transformar, 2006) ilustra de manera amplia las bondades de tomar lo social siendo parte de la sociedad. Igualmente, ella misma entra a definir el paradigma de la psicología comunitaria en las siguientes palabras:

Con su creación se buscaba producir una forma de intervención en los problemas psicosociales a fin de hacer una psicología efectivamente social, produciendo además transformaciones en las personas y en su entorno, definidas y dirigidas por esas mismas personas y no desde programas que, al prescindir de la participación de sus destinatarios, veían limitada su eficacia a la calidad de sus ejecutantes y al término de su duración. El paradigma se expresa en la psicología comunitaria a partir de los modos de hacer, al mismo tiempo que se definen sus actores, agentes externos e internos, redefiniendo sus roles y señalando el campo compartido de su acción (Montero, Introducción a la psicología comunitaria, 2004, pág. 41).

Es por tanto que se entiende que el abordaje psicológico que acá se toma, se asume como aquel que concibe a la intervención social desde un reconocimiento de lo humano como vincular, incluyendo al propio observador y que además piensa que el cambio más eficiente en estos grupos se da desde los mismos miembros de la comunidad. Los jóvenes y niños del territorio de las UPZ 69 y 70 de la localidad de Ciudad Bolívar en Bogotá, las madres comunitarias y todo el abanico de actores comunitarios, impregnan con sus matices particulares el cuadro a donde el interventor llega no solo a observar sino a ser parte del cuadro mismo. 


\section{La comunicación y la comunidad}

Sin comunicación no hay sociedad. La comunicación es la base de toda relación.

La necesidad de la relación comunicacional en la sociedad humana es algo que es incuestionable. Incuestionable como lo es en cualquier sociedad, así esta no sea humana. Esto no solo le da cabida, sino que además establece de manera tajante la necesidad de tener la mirada comunicacional en la aproximación al fenómeno social.

Siguiendo la línea de las ideas hasta acá esbozadas, encontramos en los planteamientos teóricos comunicacionales dados por La Escuela de Palo Alto, California, correspondencia perfecta a los propósitos de nuestro trabajo. Encontramos además que esta correspondencia presta una coherencia con las líneas epistemológicas y ontológicas de las demás teorías acá propuestas. Los planteamientos de la Teoría General de los Sistemas (Bertalanffy, 1989) y la psicología comunitaria (Montero, Hacer para transformar, 2006), (Montero, Introducción a la psicología comunitaria, 2004), cuentan con múltiples puntos de encuentro en relación a La Escuela de Palo Alto. Las consideraciones holísticas del objeto de estudio, la concepción de estructuras de sistemas, la consideración del desarrollo del sujeto humano relacional con respecto a su grupo, y que este sea un sujeto participativo dentro del flujo de intercambios, generan, como producto emergente, una positiva conversación interdisciplinar que busca enriquecer los alcances comunitarios de nuestra intervención.

La inclusión de la teoría general de los sistemas en el filtro de observación epistemológico de la comunicación, hizo prosperar las posturas acerca de la aproximación al fenómeno, dándole una estructura que reconocía su contexto y la importancia de este, y no solo ubicando a este contexto como un elemento accidental por fuera de estructuras rígidas y estériles de concepciones lineales y matematizadas. Paul Watzlawick, nos orienta en su libro Teoría de la comunicación humana (Watzlawick, 1997), en especial en el capítulo 4, La organización de la interacción humana, y de donde nos dice:

Cabe considerar la interacción como un sistema, y la teoría de los sistemas generales permite comprender la naturaleza de los sistemas interaccionales. La Teoría de los Sistemas Generales no se refiere tan sólo a sistemas biológicos, económicos o de ingeniería. A pesar de su diversidad, esas teorías de sistemas particulares tienen tantos conceptos en común que ha surgido una teoría más general, que estructura las similitudes en isomorfismos formales. Uno de los pioneros en este campo Ludwig Von Bertalanffy, describe esa teoría como "la formulación y derivación de principios que son válidos para los 'sistemas' en general”. Von Bertalanffy también anticipó la actitud 
de quienes reaccionan criticand o nuestro deseo de analizar las relaciones humanas a partir de una teoría que es más conocida -lo cual no significa que sea más adecuadapor su aplicación a sistemas claramente no humanos, en particular a computadoras, y ha señalado las deficiencias lógicas de esta crítica (Watzlawick, 1997, pág. 41).

Las interacciones dentro de la sociedad humana generan tendencias sociales que pueden ser estudiadas y que además pueden ser intervenidas. Las tendencias emergentes de estas comunidades no siempre son positivas y pueden llegar a perjudicar a la comunidad misma. El cambio social busca que esas tendencias, si es que estas llegan a ser negativas, se modifiquen; si son positivas, se fomenten y se preserven y si no están presentes que estas tendencias se generen y que apunten positivamente a la comunidad.

Ahora bien, en esta concepción de sistema se incluye al comunicador planificador mismo ya que en el juego comunicacional ningún actor es completamente impermeable a la influencia de su contexto y, por tanto, todo el entramado comunicacional recibe y entrega transformación en ese flujo recíproco, sumergiendo a los actores del entramado en la impronta de ese otro del intercambio, nutriendo la red misma.

\section{Las teorías y el territorio}

Lo anteriormente expuesto, busca establecer la relación entre lo aportado por la academia y lo encontrado en el territorio. Busca hacer evidente que propuestas comunitarias como la del Carnavalito, gozan de encuentros con lo que se trabaja en la academia y que estas iniciativas pueden ayudar a contribuir con el conocimiento acumulativo. Pero, también se busca que al final del proyecto, el lector, tome consciencia de que lo principal en actividades como las comunitarias, es la de entregar un aporte a la comunidad misma, es entregar herramientas que contribuyan al crecimiento de sus integrantes y de mejorar sus proyecciones inmediatas y futuras.

En este diálogo entre la academia y el territorio es donde se reconoce la importancia de los aportes de otros autores, pero sobre todo se reconoce la importancia de no imponer la teoría sobre las realidades sociales, que con su vida propia muestran su particularidad e identidad. El tratar de encajar lo que tuvo éxito en otro espacio social solo genera distorsiones que pueden acarrear más perjuicios que beneficios. 


\section{Empoderamiento}

“...el ciudadano o la ciudadana, es la persona que cada día genera poder en medio de sus relaciones cotidianas, y usa este poder para ir transformando su comunidad en pos de una visión de futuro.” (Rodriguez, 2013, pág. 100).

Independiente del autor o la disciplina que haga uso del término 'empoderamiento', todos inician con la cita obligada del término de 'poder', ya que es este el centro, el eje desde donde se empieza a articular el concepto de empoderamiento. Enarbolar el poder, obtenerlo, negociarlo, usarlo, reconocerlo, tomar conciencia de él, son parte de los ítems que los autores usan para hablar de la relación del empoderamiento y del poder.

De este amplio y apasionante tema debemos, para el interés de este texto, alinearnos con la definición de empoderamiento de Jo Rowlands ( (Rowlands, 1997), quien entendió el empoderamiento como la relación de poder y las formas en las que este opera.

En este sentido para ella son cuatro las variantes de la operación del poder: El poder sobre, El poder para, el poder con y el poder interno o poder desde adentro.

El poder sobre se entiende como aquel en donde se necesita de una contraparte sumisa a aquel que ostenta el poder. Es el poder que entiende que para ganar poder otro tiene que perderlo, como el movimiento en una balanza que sube o baja dependiendo del peso de cada uno de sus brazos. Es lo que autores como Craig y Mayo (Craig \& Mayo, (2004/1995)) describen como el poder de suma cero, pues es un poder competitivo que busca acumular poder despojando a los contrarios del mismo.

Estos mismos autores afirman que contrario a el poder de suma cero existe el poder de suma positiva o suma variable donde se entiende que en una comunidad todos ostentan poder en mayor o menor medida, pero que al unirse se potencia el poder. El poder de suma positiva puede contener a las operaciones de poder para, poder con y poder interno, trabajada por Rowlands, ya que estos, aún con sus diferencias, cuentan con el patrón común potencializador, ya que no necesita de despojar poder para hacerse presente, muy al contrario, busca la asociación para incrementarse.

En esta medida debemos saber que las funciones que se entiendan del empoderamiento también tienen que estar relacionadas con lo que se busca del poder.

Continuando con Jo Rowlands (Rowlands, 1997), ella entiende que el empoderamiento es la capacidad de poder intervenir en la toma de decisiones acerca del control político y distribución de los recursos por parte de aquellos que eran ajenos a estas decisiones. Y que para que se pueda dar este escenario el empoderamiento tiene que tener un desarrollo en tres dimensiones: El personal, el relacional y el colectivo. 
El personal es en donde se desarrolla la capacidad del sí mismo y capacidad individual, el relacional donde se desarrolla la negociación y la influencia de las relaciones, y, el colectivo es donde se reconoce la bondad del trabajo en conjunto mejorando el que se haría de manera individual.

\section{Figura 2}

RELACIÓN DEL TIPO DE OPERACIÓN DE PODER Y LA DIMENSIÓN DE EMPODERAMIENTO DESARROLLADA

\begin{tabular}{|c|c|c|c|c|c|}
\hline & & Poder de suma cero & Poder & ma pos & \\
\hline & $\begin{array}{l}\text { Operaciones } \\
\text { del poder }\end{array}$ & Poder Sobre & $\begin{array}{l}\text { Poder } \\
\text { Para }\end{array}$ & $\begin{array}{l}\text { Poder } \\
\text { Con }\end{array}$ & $\begin{array}{l}\text { Poder } \\
\text { Interno }\end{array}$ \\
\hline 웜 & Personal & Alto & Medio & Medio & Alto \\
\hline 导 & Relacional & Alto & Alto & Alto & \\
\hline 氖 & Colectivo & & Medio & Alto & \\
\hline
\end{tabular}

Cuadro de elaboración propia. Es necesario entender que no por ubicarse en un cruce o dimensión u operación necesariamente se excluya lo demás. A menos que sea entre poder suma cero y suma positiva.

El empoderamiento es una pieza clave en los procesos de intervención social. El tomar consciencia de la relación de poder y el actuar sobre ello es indispensable para hacer que una comunidad y sus integrantes sean artífices de sus propios cambios. Que los integrantes de estas comunidades sean constructores de sus propias realidades, también genera que se tome consciencia de que ellos, muchas veces, son prisioneros de sistemas que buscan perpetuar su vulnerabilidad.

El Carnavalito es una expresión de la comunidad, es una prueba materializada de la búsqueda de los líderes y la comunidad misma para organizarse y apoderarse de las condiciones que los rodean, para transformar, para orientarse hacia la construcción de una comunalidad que no dependa de las eventualidades brindadas por las precarias aportaciones del Estado y de grupos criminales que pretenden apoderarse de su territorio.

El empoderamiento colectivo e individual se tiene que entender como un entramado colaborativo, en donde se evidencie que una de las máximas de la comunidad tendría que ser: "la mejora de mi comunidad es la mejora de mí mismo, y la mejora de mí mismo es la mejora de mí comunidad, en la medida de que potencie a mis pares”, entendiéndose entonces que 
buscamos un empoderamiento de suma positiva, en donde no tenga que restarle al otro para empoderarme, sino en fortalecernos para que sumemos todos.

\section{Derechos humanos}

La carta magna de protección de los derechos más mínimos a la humanización de la humanidad es la registrada en los derechos humanos establecidos en la Declaración Universal de los Derechos Humanos.

La Declaración Universal de los Derechos Humanos (DUDH) es un documento que marca un hito en la historia de los derechos humanos. Redactada por representantes de todas las regiones del mundo de diferentes culturas y tradiciones jurídicas, la Declaración fue proclamada por la Asamblea General de las Naciones Unidas en París, el 10 de diciembre de 1948 en su Resolución 217 A (III) como un ideal común para todos los pueblos y naciones. Estableció, por primera vez, derechos humanos fundamentales que deben protegerse universalmente. (Naciones Unidas, 2020).

Y estos mismo se definen como:

Los derechos humanos son derechos inherentes a todos los seres humanos, sin distinción alguna de raza, sexo, nacionalidad, origen étnico, lengua, religión o cualquier otra condición. Entre los derechos humanos se incluyen el derecho a la vida y a la libertad; a no estar sometido ni a esclavitud ni a torturas; a la libertad de opinión y de expresión; a la educación y al trabajo, entre otros muchos. Estos derechos corresponden a todas las personas, sin discriminación alguna. (Naciones Unidas, 2020).

La violación a estos derechos implica una fuerte declaración de traspaso de las fronteras mínimas que protegen a los individuos, a los grupos y organizaciones, y por tanto, un crimen absoluto contra la humanidad.

Las funciones y compromisos de estos van más allá de la mera presentación de las buenas formas de convivencia e ideales de interacción humana, estos son compromisos de tipo formal que son parte incluso de muchas constituciones nacionales de diferentes países del mundo.

Esta declaración universal abriga ese deseo de muchas luchas que buscaron un umbral mínimo de dignidad humana, esperando que esta pudiese verse "materializándose en la asunción interactiva de deberes para con los demás, para con nosotros mismos y para con la 
naturaleza" (Herrera Flores, El proceso cultural: Materiales para la creatividad humana., 2005, pág. 323).

No estamos ante privilegios, meras declaraciones de buenas intenciones o postulados metafísicos que plantean una definición de la naturaleza humana aislada de las situaciones vitales. Por el contrario, los derechos humanos constituyen la afirmación de la lucha del ser humano por ver cumplimentados sus deseos y necesidades en los contextos vitales en que está situado. (Herrera Flores, La reinvención de los derechos humanos, 2008, pág. 14)

En esta misma Declaración Universal de Derechos Humanos, en su Artículo 19, se reconoce el derecho a la información y a la libertad de expresión y opinión. Este apartado fortalece la defensa de la voz de toda la humanidad como el derecho a la comunicación, sin importar sus características particulares.

El Derecho a la Comunicación recoge todos los demás derechos adquiridos en el devenir histórico, a la vez se torna extensivo para responder a los tiempos presentes. Dos son los principales ingredientes que gravitan en esta esfera: uno, el consenso que se ha ido estableciendo en la comunidad de naciones respecto al imperativo de profundizar la democracia con la participación ciudadana en la toma de decisiones, cuestión que remite a la necesidad de potenciar la diversidad y pluralismo en el mundo mediático; y, dos, el vertiginoso desarrollo de las nuevas tecnologías de información y comunicación, bajo la matriz de la convergencia digital, que entre otras cosas establece condiciones operativas de interactividad. (León, 2013, pág. 13).

En la búsqueda de esa pluralidad comunicacional es que el carnavalito se presenta como un espacio abierto a la participación de la comunidad. Un espacio multicolor no solo relacionado a lo estético de la caravana sino a la variedad de posturas y actitudes de sus participantes. Este uso del espacio del territorio busca irrumpir con un aislamiento impuesto por esas fuerzas de grupos que hacen uso de la violencia para acallar, violentando el legítimo derecho humano y comunitario de tener una voz y comunicar. La retoma de este espacio discursivo no es solo un acto festivo, sino también es un acto político, pues cada participante de estos ejercicios actúa y decide sobre el territorio en el que habita y apoya con su intervención una postura social y de la misma manera rechaza unos actos que van en contra del sano desarrollo de su comunidad 


\section{Transformación social}

La transformación social debe entenderse en términos funcionales, pero no solo de pragmática, sino como propósito principal de las intervenciones de las investigaciones sociales, ya que su objeto de investigación son los grupos de personas y sus interacciones y, por tanto, sus dinámicas tendrán una afectación humana. Lo que implica tener a la ética como material principal de estas aproximaciones. Es entonces cuando se puede entend er que en la investigación e intervención social, más allá de la acumulación de conocimiento, se busca que el conocimiento establecido y residual de la investigación acarree beneficios para la comunidad intervenida.

Para entender el cambio social debemos establecer que el objeto de estudio es el aquello social, compuesto por los sujetos y su interacción. Y que el cambio se da con la intervención tanto del investigador como de los integrantes del grupo social intervenido, en un proceso que Orlando Fals Borda denominaba El Principio de Catálisis Social, y a este se refiere como:

El proceso de cambios que se desarrollan por virtud de la presencia real de portadores de cultura activos en medio de un grupo, y cuya función es de constante vigilancia para asegurarse de que las nuevas prácticas se continúen sin necesidad de estímulo, de que no se cometan errores en las adopciones y de que las necesidades latentes se conviertan en necesidades manifiestas, por la formación de nuevos hábitos (Fals Borda, 1959, pág. 51).

Continuando lo anterior Maritza Montero complementa la concepción de catálisis así: La idea de la catálisis explica la intervención inicial del investigador o agente externo como se lo denomina en la psicología comunitaria. Y ella se basa en la comunicación y confianza que se establezca entre esos agentes externos y los agentes internos de cambio (miembros de la comunidad y grupos organizados dentro de ella). La formación de líderes comunitarios es una de sus tareas, debido al rol fundamental que juegan las personas afectadas por la situación a cambiar. (Montero, Hacer para transformar, 2006, pág. 136).

Es con esto que se aclara que en el cambio social se necesita que se presente un cambio en el grupo abordado a través de la intervención de agentes externos y su propia intervención como comunidad. Esto buscando que ha futuro sea más estable este cambio, ya que se utilizan los recursos de la misma comunidad, sus normas, sus códigos, sus expectativas, entre otros muchos conceptos propios. 
Todo lo anterior entendiendo que en la realidad en donde se constituyen los procesos sociales, estos son desarrollados a través de relaciones dinámicas y dialécticas:

La realidad existe porque es construida, reconstruida y destruida de innumerables formas cada día; por lo tanto, en ese mismo sentido, un sujeto cognoscente es todo ser que en su relación con el mundo que lo rodea y al cual pertenece, produce y reproduce conocimiento, además de ser actor de ese proceso. Y al hacerlo construye realidad y es construido por la realidad que construye. Pero no es un actor individual, aislado, único en cada proceso. Se trata de un ser que sólo existe en relaciones, de un ser cuya naturaleza es social porque es capaz de mantener múltiples relaciones en las cuales genera, con otros seres, el conocimiento. (Montero, Hacer para transformar, 2006, pág. 149).

Entendemos entonces que, cambiando a los sujetos y sus dinámicas, se cambia lo social, ya que estos sujetos no surgen del solipsismo ${ }^{20}$ sino, muy al contrario, de su encuentro con los otros.

Ahora, por necesidad conceptual, tenemos que entender cómo se puede definir lo que se entiende como grupo social, para lo cual nos basamos en la teoría general de los sistemas de Ludwig Von Bertalanffy (Bertalanffy, 1989) que nos ayuda a entender que a los grupos o sistemas se les puede definir a partir de ciertas características dentro de las cuales cabe resaltar que las principales son: la totalidad, la sinergia, la homeostasis y la entropía. Que en relación a los grupos sociales sería definible de la siguiente manera:

Totalidad: entender o dimensionar cuales pueden llegar a ser los alcances, las distancias o las fronteras del grupo al que se está investigando, para de esta manera tratar de abarcar en lo posible la mayor cantidad de sujetos e interacciones y ser más precisos en la aproximación y en su intervención.

Sinergia: que se reconozca que el grupo social es más que la simple suma de sus elementos y que estos en su conjunción generan nuevas dinámicas que no se presentarían sin la interacción de estos.

La homeostasis: que el grupo social encuentre un equilibrio en la vinculación entre sus individuos y que este ayude a tener una continuidad en el tiempo. Con esto, reconocer que la estabilidad define al grupo y no que solo este se presenta por un espacio de interacción esporádico. Aunque acá se debe resaltar que esa homeostasis o equilibrio no siempre es positiva, muchos grupos a través de la historia han sido estables manteniendo aspectos muy

\footnotetext{
${ }^{20}$ Instancia en donde el sujeto, en su individualidad, no reconoce la existencia de aquello que no sea el sí mismo.
} 
negativos para la humanidad, el feudalismo con esclavos y el oscurantismo de la edad media son un ejemplo de esto. Fueron muy estables, pero no muy positivos.

Entropía: es el reconocer que dentro del sistema se pueden presentar conflictos que pueden generar discordancias que desencadenen desorden. En los grupos sociales se entiende que las opiniones en relación a algo pueden tener encuentros que coincidan pero que nunca se van a dar en un $100 \%$, más aún cuanto más grande sea el grupo.

El reconocimiento de nuestro grupo social en la comunidad alrededor del Carnavalito se da de la siguiente manera: la totalidad o fronterización la encontramos en la zona por donde se presenta esta manifestación popular y en todas aquellas personas que forman parte de esta voz comunitaria, desde los gestores de la misma, pasando por los padres y niños marchantes hasta llegar al transeúnte ocasional que se encuentra en una calle de su barrio con una marcha. La sinergia la encontramos al conjugar en una fecha y un lugar, con trazados específicos; a los participantes del Carnavalito, que en su unidad hacen más que en sus individualidades, y de igual forma en las actividades de gestión del mismo. La homeostasis o equilibrio, la vemos al encontrar una recurrencia y una constancia en la manifestación por parte de la población que ya se identifica con esta y que ya la ha hecho parte de su calendario de actividades, dand o cuenta de una interiorización de una práctica cultural con raíces populares del territorio. La entropía se encuentra en la resistencia que tienen algunos habitantes de la zona, que no son parte de las marchas, ya sea por desinterés, desidia, pereza, incredulidad o ideologías que no se encuentran con las del Carnavalito.

Definido lo anterior, es cuando encontramos que el cambio esperado en la comunidad se da a través de lo que se ha denominado como catálisis social (Fals Borda, 1959), y es cuando los agentes comunitarios entran en acción en la comunidad misma, tanto los integrantes de la comunidad como los ajenos a ella. Los investigadores hacen parte de esta construcción no sólo como agentes pasivos sino como sujetos de cambio que cambian también con su intervención.

\section{Identidad}

Es muy frecuente encontrar dentro de las charlas del cotidiano vivir, la palabra identidad, referida hacia una persona o un grupo de estas, desplegando una lista de adjetivos que pueden ir cercando la idea que se tenga acerca de la persona o personas de las que se está haciendo mención, pero, ¿qué es la identidad? Para iniciar esta aproximación se debe tener en cuenta que este término tan cotidiano tiene una gran repercusión en estudios de las ciencias humanas contemporáneas, pero que este puede tener principios ontológicos que hacen que se deba tener cuidado a la hora de trabajarse. En este sentido debemos distinguir 
dos orientaciones que toma el término identidad, la primera llevada a elementos más individuales y aislados por y en cada persona, una orientación trabajada generalmente por disciplinas como la psicología no relacional, una psicología frecuentada por posturas próximas al solipsismo del desarrollo ${ }^{21}$, generalmente entendida para el desarrollo del Self (Erikson, 1959), ( (Marcia, 1980). La segunda orientación del término va dirigida hacia una construcción relacional, hacia una conjunción de subjetividades, hacia una formación del sujeto vincular, que es reactivo a su contexto (Smith, 1997), (Rojas Gomez, 2011). Ya que son enfoques que ameritan de un gran detalle, he de aclarar que nuestro interés se centrará en la segunda orientación, ya que el objeto del texto hablará de procesos sociales entre sujetos.

Aclarado lo anterior podemos empezar a entender que describir una identidad es enumerar una serie de características asociadas hacia aquello de lo que estamos denominando, por tanto, ésta recae en una categoría lingüística o comunicacional. Esta categoría a su vez no puede existir en ausencia de un contexto social, lo que nos lleva a concluir que la identidad se establece en la atmósfera de lo social y se construye a través del lenguaje. Esta situación relacional de la identidad con lo social es lo que establece al sujeto como elemento contenedor de esa identidad.

Ahora bien, en este punto debemos entender dos factores claves acerca de la formación de esta identidad a la que queremos aproximarnos. El primer factor es cómo se delimita la identidad particular en el sujeto en el campo de lo lingüístico y el segundo factor es cómo se establece a través de lo social; en ese orden.

Para entender la naturaleza de la identidad y haciendo un ejercicio mental podemos empezar a entender que no podemos denominar algo que no existe (en nuestro campo de percepción fenomenológico), por tanto, el percatarnos de su presencia hace que empecemos a diferenciarlo de eso otro que ya conocemos como independiente. Para ejemplificar esto podemos pensar en la piel, en la piel propia o la de cualquier persona; es el órgano que recubre los cuerpos y a ojos de muchos es la misma piel, pero un dermatólogo, un cirujano e incluso un tatuador pueden discriminar las diferentes capas que constituyen esa misma piel. Una piel que para muchos es solo la capa protectora del cuerpo. Entonces los expertos en piel pueden señalar y describir sus componentes, tipo de espesor, melanina, colágeno, circulación sanguínea, etcétera, lo que nos deja en este momento reconociendo que hay varias denominaciones para lo que antes pensábamos que era una sola denominación: “piel”.

\footnotetext{
${ }^{21}$ Postura que niega la realidad ajena alsí mismo. Postura teó rica que se enfoca más en reconocer al individuo aisla do de todo su entorno,
} 
Es ahora cuando reflexionamos en que la piel de nuestro hombro no es igual a la piel de nuestros labios o la piel de las palmas de las manos. Entonces lo que hemos hecho es empezar a reconocer "la diferencia", y es en esta que radica la esencia de la identidad, pues la diferencia es la que le da frontera a la identidad. En ausencia de la diferencia la identidad se extendería y por tanto no sería discriminable y como resultado no se podría denominar. Pensemos lo mismo, pero con el ejemplo de la piel, lo que antes mencionamos como una generalidad ahora se reconoce como un grupo de pieles con características bien definidas, ya no es la piel simplemente, ahora son pieles diferenciadas con identidad. Pues pasa lo mismo con la formación de la identidad en personas y grupos.

Pensar en que la identidad se establece necesitando la diferencia nos lleva al segundo factor, que es derivado del primero y es que, ya que entendemos que la denominación de un algo, en este caso la identidad, necesita de la diferencia para establecerse, ubica al sujeto en un lugar de diferencia respecto a otros sujetos, por tanto, se entiende que esa sujeción de nuestro sujeto se da con sus semejantes y que reconoce como diferentes a los otros; diferentes, no mejores, ni peores, diferentes. Pero, qué pasa cuando este balance cambia, pues que los grupos de sujetos empiezan a generar jerarquías y por tanto condiciones dentro de las realidades sociales. Estas realidades sociales conviven con sistemas comunicacionales que crean nuevos sujetos y por tanto refuerzan la estructura y es en este punto que podemos reconocer a los discursos de poder como los mecanismos lingüísticos que pueden fomentar exclusión social. Con un uso instrumental e inadecuado esta es un arma con el mayor de los daños para sociedades desiguales, pero de altísimo beneficio cuando se está bien dirigida ya que puede generar vinculación en un positivo tejido.

Hasta este punto podemos establecer que la identidad se forma a través del lenguaje, un lenguaje que necesita de la diferencia, necesaria solo para entender los contrastes, no para discriminar, al igual que necesita de un lenguaje que circula por lo social a través de otros sujetos, sujetos que a su vez están inmersos en relaciones de poder sustentadas por los discursos, entonces sabemos que los discursos forman identidad.

Ya que la función del Carnavalito es ofrecer un nuevo discurso a la realidad comunitaria de los barrios del sur de Bogotá por donde se marcha, se busca generar en estos una identidad descrita con adjetivos positivos. Adjetivos que circulen por los sujetos partícipes del territorio y que se sustente en esas redes comunicacionales a través de los discursos cotidianos creando arraigo y pertenencia. 


\section{Memoria}

Cuando escuchamos el término memoria, generalmente se organizan ideas en torno a procesos mentales, que pasan en el cerebro de las personas o de los organismos con un sistema nervioso altamente desarrollado. Ubicamos a la memoria como un proceso mental que se puede encontrar entre la sensación, la percepción, el aprendizaje, el lenguaje y el razonamiento (Gluck, 2009), direccionando a la memoria en sus acciones pertenecientes a una entidad sin relación a su contexto, o, en otras palabras, ubicamos la memoria en un individuo con actividades internas sin que se tenga necesidad de vincularlo con otro. Es desde esta postura que la memoria entra a recibir una definición que, a grandes rasgos, José María Ruiz-Vargas (1991) nos describe como:

La memoria está diseñada para adquirir, guardar y retener, y devolvernos puntualmente registros de informaciones y de experiencias pasadas que nos ayudarán a resolver con éxito los problemas actuales. Por todo ello, la memoria podría definirse como la capacidad [...] para adquirir, almacenar y recuperar diferentes tipos de conocimiento y habilidades. (Ruiz-Vargas, 1991, pág. 23).

Entendiendo esta definición podemos empezar a establecer unas estructuras del funcionamiento de este proceso, pero, es cuando miramos este concepto de memoria y, con la ayuda de la analogía, lo ampliamos a grupos sociales y entendemos la funcionalidad de esa memoria, que nos encontramos con esa relación entre el pasado y el presente de esos mismos grupos sociales. Es cuando este proceso se sale de la individualidad e ingresa a ese intercambio de subjetividades, que no necesariamente son estáticas y fugaces, sino que trascienden a través del tiempo. De esta manera se reescribe la ontología del proceso "Memoria", dejando como centro de interés a los intercambios sociales a través del tiempo y no a los eventos internos con manifestaciones evaluadas conductualmente.

La riqueza de reconocer la memoria en los grupos sociales, viene del que, con el solo hecho de concebirla, ya se hace una alusión e implicación a la trascendencia en el tiempo; ya se adjudica una historia y es de ahí donde deviene su importancia. El grupo social no es una manifestación eventual, es una constante con vida.

Esta memoria histórica da cuenta de los recursos a los que puede acudir una comunidad para interpretarse a sí misma, ya que contiene los componentes para edificar sus identidades. De ahí lo clave de administrarla para evitar que se distorsione a conveniencia de posturas particulares que no reconozcan a la comunidad y que terminan volviéndose la "historia oficial", que bajo la tutela del poder desmiente u oculta hechos claves de las comunidades. Entonces vemos que la importancia de esa memoria histórica se da en la medida de que a 
través de la conmemoración acote hechos invisibilizados que deterioran el tejido social, tan importante para el sano desarrollo comunitario.

Las conmemoraciones, sus rituales y sus posibles consecuencias, son descritas claramente por Amalio Blanco Abarca y Jesús Rodríguez Marín (Blanco Abarca \& Rodríguez Marín, 2007) a través del recuento de la memoria histórica en una comunidad de víctimas de la violencia y que clasifican, ayudándonos a familiarizarnos con esta temática, de la siguiente manera:

De capital importancia en la reparación del tejido social, de la recuperación de la memoria histórica y de la recuperación socio-afectiva de personas y comunidades son las conmemoraciones vinculadas a hechos terroríficos tales como masacres, detenciones arbitrarias masivas, desapariciones forzadas, tortura y desplazamientos. Las conmemoraciones ayudan a la rememoración de eventos colectivos, pero los rituales asociados a estas conmemoraciones cumplen unas funciones sociales que van más allá de los eventos conmemorados. En primer lugar, revisten de dignidad los sentimientos de los sobrevivientes. Es bastante común que la historia oficial señale como sospechosos esos sentimientos personales y colectivos. Más aún, los mismos sobrevivientes se habrán mostrado reticentes en exhibirlos públicamente por temor a represalias y porque en el caso de desapariciones o asesinatos, la presentación pública de esos sentimientos los pondría en peligro. En situaciones de violencia organizada, los sobrevivientes con frecuencia no han podido ni siquiera pronunciar los nombres de los familiares, hablar sobre las circunstancias de su muerte o desaparición ni mucho menos señalar los culpables ni iniciar procesos tendientes a esclarecer el paradero de los que han desaparecido. (Blanco Abarca \& Rodríguez Marín, 2007, pág. 189).

Estas funciones sociales son la repercusión de los alcances de la memoria histórica.

Este recuento nos ayuda a vislumbrar los asideros reales en las situaciones de los integrantes de las comunidades.

En segundo lugar, los rituales de conmemoración revisten de objetividad los sentimientos generados en los sobrevivientes. No son los sentimientos privados de algunas personas cuya salud mental se puede poner en entredicho. Se presentan públicamente y de esa manera tienen validación social porque los poseen muchos otros que comparten una narración y una historia. Quedan clarificados los papeles que distintas personas, grupos e instituciones han jugad o en la historia colectiva, en cuyo significado se quiere adentrar. Aparecen claramente los victimarios, sus intenciones y sus instrumentos; las víctimas, sus proyectos y los recursos sociales que demandan 
tener para poder llevarlos a cabo; los cómplices y su conspiración de silencio con la cual han avalado la historia oficial y pervertido el significado del sufrimiento de personas y comunidades; los que se mostraron solidarios con el dolor, la tragedia de las personas y comunidades, y el horror. Es en y a través de estas conmemoraciones que los sobrevivientes llegan a entender los sentimientos que ellos albergan, su extensión y el impacto que causan en otros ámbitos de su vida personal y colectiva.

Al objetivarse los sentimientos de las víctimas en este diálogo intersubjetivo se sientan las bases para revertir la historia desde ellas ya que la historia oficial encuentra su contrapunto precisamente en lo que y en quienes ésta ha querido olvidar. Obedece, por un lado, a los deseos de los victimarios de continuar viviendo en la impunidad y de gozar de los expolios sociales de su victoria o ascendencia y, por otro lado, a los deseos de las víctimas bien de «cerrar» un capítulo doloroso de sus vidas o de disminuir su cotidiana vulnerabilidad. (Blanco Abarca \& Rodríguez Marín, 2007, págs. 189, 190). Pero, en estos usos de la memoria histórica y su proceso de conmemoración, vemos que estas se pueden enfrentar a los bloqueos de las herramientas usadas habitualmente por los que defienden esa historia oficial, que no buscan otra cosa que desmentir a la comunidad y consolidarse como la verdad, una verdad que les es conveniente. El olvido y la sospecha son herramientas que se hacen presentes para interrumpir los alcances comunitarios.

Por medio del primero, el olvido forzado, los victimarios imponen su propia versión de los hechos. Para lograrlo se valen de la omisión selectiva de acontecimientos importantes y la manipulación de las vinculaciones entre los hechos (Rosa, Bellelli y Bakhurst, 2000). La sospecha, por otro lado, tiene una doble función. En primer lugar, va dirigida a romper los lazos de solidaridad que pudieran existir entre las víctimas y la población civil, debilitando la empatía que suelen demostrar personas de buena voluntad ante la brutalidad, y especialmente cuando ésta proviene del Estado. En segundo lugar, produce cierto auto-embellecimiento al presentarse los victimarios como las verdaderas víctimas de historias insidiosas urdidas por personas confundidas o por personas mal intencionadas. (Blanco Abarca \& Rodríguez Marín, 2007, pág. 190). Y de esta manera, Amalio Blanco y Jesús Rodríguez (Blanco Abarca \& Rodríguez Marín, 2007), nos ayudan a despejar los mecanismos ocultos presentes en la historia y continúan describiendo los alcances de la memoria histórica.

En tercer lugar, las conmemoraciones colectivas, si bien tienden a intensificar los sentimientos de dolor y de injusticia experimentados por las víctimas o sus familiares, también propician la solidaridad y movilización social, procesos que empoderan para 
reclamar que sus historias queden recogidas en el imaginario social. (Blanco Abarca \& Rodríguez Marín, 2007, pág. 190).

Sin estos sentimientos de pertenencia y unión, las narraciones de las víctimas quedarían relegadas a relatos conmovedores pero que, en definitiva, no pasarían de ser relatos individuales, tragedias personales. La solidaridad y la movilización que se derivan permiten la acción colectiva que, al conseguir recursos psicológicos, sociales y físicos, visibiliza el entramado político en el que se encuentran no tanto ya las personas individuales cuanto los grupos y comunidades a las que éstas pertenecen. La acción colectiva contribuiría, así, a la obtención de bienes colectivos necesarios en la reparación del tejido social: igualdad de derechos, procuración de justicia, formulación de políticas que garanticen una paz duradera, garantías jurídicas y debido proceso, reparación, reconciliación.

En cuarto lugar, las conmemoraciones colectivas dignifican la vida de las víctimas que no lograron sobrevivir el impacto de la violencia institucionalizada. Quedan dignificadas en la memoria de todos los sobrevivientes (aquellos que guardaron una relación familiar o de amistad y los que no los conocieron), y sobre todo quedan dignificados en el imaginario social al quedar colocadas correctamente en la historia colectiva.

En resumen, la acción de hacer memoria desde la óptica de las víctimas es un contrapeso indispensable para la reconstrucción del tejido social y la reconciliación después de un conflicto armado. La reconstrucción del pasado que incorpore las narrativas de las víctimas radicaliza el futuro ya que éste no puede concebirse como más de lo mismo — que es lo que garantiza la impunidad—. (Blanco Abarca \& Rodríguez Marín, 2007, págs. 190, 191).

Así bien, podemos ver que hemos recabado en la concepción de la memoria en su idea más aislada para asimilar después su función social y las implicaciones de la misma, entendiendo la importancia de su reconocimiento y cuidado.

La memoria en una comunidad barrial como la de las UPZ 69 y 70 de Ciudad Bolívar en Bogotá, enmarca una atmosfera de falencias que en las últimas décadas ha sido irrumpida por voluntades de cambio, intencionalidades de transformación, que en su constancia han marcado un notable desarrollo hacia una construcción de territorio en, por y para el territorio mismo. La memoria como sustento de procesos actuales y de proyecciones a futuro que aborda ese para qué de las intervenciones, accionando sobre las problemáticas que han sido reconocidas como negativas, afrontándolas para cortar con su influencia. La memoria como 
guía para construir propuestas que reemplacen las problemáticas por caminos de transformación y desarrollo. La memoria como base para el crecimiento. La memoria como recuento de una historia contada por la voz propia y no por imposiciones de grupos particulares soportados por el hegemón de las instituciones totalitarias; la memoria para la libertad.

\section{Comunidad}

La definición de comunidad muchas veces se puede pensar que tiene una respuesta intuitiva, ya que nos sabemos pertenecientes a una comunidad o varias y esto lo entrevemos desde el despertar de nuestras conciencias en nuestro desarrollo personal. Generalmente hacemos una descripción extensiva de las características de las comunidades a las que pertenecemos o de las que podemos dar cuenta, pero, no se pasa de la descripción de sus características, entonces nos damos cuenta que lo más difícil de conceptualizar es eso que muchas veces damos por hecho. Es entonces cuando tenemos que hacer uso de una mirada más fina hacia ese elemento.

Para definir la comunidad entonces podemos respaldarnos en una línea de la psicología que construye su quehacer en torno al eso comunitario, entendiendo por eso su mismo nombre, psicología comunitaria. En esta disciplina podemos encontrar definiciones, ya clásicas, que daban a entender a la comunidad como una referencia al espacio geográfico, en donde se departían las interacciones de un grupo social. Pero este ámbito geográfico se tornó bastante limitado y “...posteriormente fue importante tomar en cuenta también los factores psicosociales involucrados en estas agrupaciones humanas, subrayando los factores intersubjetivos, de memoria histórica y formas de vida que caracterizaban a dichas comunidades" (Montenegro, 2004, pág. 19).

Ya con esto presente podemos citar a María Isabel Hombrados Mendieta (Hombrados Mendieta, 2013, pág. 59), quien de una manera sencilla nos ayuda a pensar este marco en tres líneas: "La comunidad puede ser entendida bajo tres acepciones, como: 1. Un lugar (ubicación y características del entorno físico). 2. Un conjunto de personas (características sociales de sus habitantes). 3. Un sistema social (pautas de interacción y redes sociales).”

Es acá donde vamos ampliando la idea de lo que se entiende por comunidad, pero, también vemos que estas características también tienen otras particularidades. Una de ellas es la percepción que pueda tener el integrante de esa comunalidad en relación a su grupo y a los otros grupos: 
Se crea, a partir de estas agrupaciones, un nosotros que se conforma en contraste con un otros definido en función de las personas que no forman parte de esa comunidad. Se dan, por tanto, unos procesos de categorización social donde cada grupo se define como semejante a los elementos presentes en el endogrupo y diferente a los elementos del exogrupo. (Montenegro, 2004, pág. 19).

Otro aspecto a tener en cuenta es que, aunque hablemos de comunalidad, lo que se encuentra en estos grupos sociales es la diferencia, y es importante considerarla ya que de esta manera reconocemos las particularidades de sus miembros y no solo atendemos a la masa grupal como elemento de interés.

Es preciso considerar la heterogeneidad y complejidad de las relaciones comunitarias a la hora de desarrollar nuestro trabajo en comunidades concretas, ya que la complejidad de tales relaciones puede influir en las formas en las que se toman decisiones o se desarrollan acciones de transformación social en los procesos comunitarios que emprendemos. (Montenegro, 2004, pág. 20).

Entendiendo acepciones de las particularidades mencionadas, podemos encontrar unas generalidades del concepto de comunidad con las que podemos trabajar y para esto entendemos la claridad con la que Maritza Montero (Montero, Introducción a la psicología comunitaria, 2004) nos ayuda en esta tarea:

Una comunidad, entonces, está hecha de relaciones, pero no sólo entre personas, sino entre personas y un lugar que, junto con las acciones compartidas, con los miedos y las alegrías, con los fracasos y los triunfos sentidos y vividos otorga un asiento al recuerdo, un nicho a la memoria colectiva e individual. Un lugar construido física y emocionalmente del cual nos apropiamos y que nos apropia, para bien y para mal. (Montero, Introducción a la psicología comunitaria, 2004, pág. 99).

Y continúa:

Una comunidad es un grupo en constante transformación y evolución (su tamaño puede variar), que en su interrelación genera un sentido de pertenencia e identidad social, tomando sus integrantes conciencia de sí como grupo, y fortaleciéndose como unidad y potencialidad social.

La comunidad es, además, un grupo social histórico, que refleja una cultura preexistente al investigador; que posee una cierta organización, cuyos grados varían según el caso, con intereses y necesidades compartidos; que tiene su propia vida, en la cual concurre una pluralidad de vidas provenientes de sus miembros; que desarrolla formas de interrelación frecuentes marcadas por la acción, la afectividad, el 
conocimiento y la información. No debe olvidarse que, como parte de su dinámica, en esas relaciones internas puede también llegar a situaciones conflictivas conducentes a su división, su disgregación y a la pérdida de identidad. (Montero, Introducción a la psicología comunitaria, 2004, pág. 100).

Como remanencia de lo anterior podemos citar un listado de aspectos constitutivos del concepto de comunidad (Montero, Introducción a la psicología comunitaria, 2004, pág. 96):

- Aspectos comunes, compartidos:

- Historia.

- Cultura.

- Intereses, necesidades, problemas, expectativas socialmente construidos por los miembros del grupo.

- Un espacio y un tiempo.

- Relaciones sociales habituales, frecuentes, muchas veces cara a cara.

- Interinfluencia entre individuos y entre el colectivo y los individuos.

- Una identidad social construida a partir de los aspectos anteriores.

- Sentido de pertenencia a la comunidad.

- Desarrollo de un sentido de comunidad derivado de todo lo anterior.

- Un nivel de integración mucho más concreto que el de otras formas colectivas de organización social, tales como la clase social, la etnia, la religión o la nación.

- Vinculación emocional compartida.

- Formas de poder producidas dentro del ámbito de relaciones compartidas.

- Límites borrosos.

\section{Planificación y gestión, el pensar y el actuar}

“Una planificación para emancipar, no para controlar" (Ceraso, Redes de Desarrollo

Local y Colectivos de Comunicación en el Territorio, 2008, pág. 50)

Cuando pensamos situaciones en donde podríamos aportar a la comunidad encontramos fácilmente experiencias en las que observamos que algunos interventores se han dejado llevar por impulsos, incitados por fuerzas que en ocasiones son momentáneas y que, aunque puedan haber nacido de fuentes llenas de buenas voluntades, pueden llegar a causar un retraso en lugar de un avance en los propósitos de la comunidad. La desconfianza en las intervenciones, el desgaste, el desinterés, son parte de esas consecuencias encontradas por intervenciones relámpago. 
El establecer una proyección más meditada, con unos propósitos más elaborados, nos invita a definir una secuencia de pasos que nos guíen hacia la consecución de esos ideales esperados para la comunidad. Es por tanto que la importancia de la planificación en tanto herramienta de construcción, es crucial en los aportes comunitarios.

"La planificación es la tecnología que utilizamos para diseñar nuestra apuesta de transformación. Implica poner en relación lo que pasa en la realidad con lo que deseamos que ocurra para pensar el camino estratégico que nos acerca al futuro deseado." (Ceraso, Redes de Desarrollo Local y Colectivos de Comunicación en el Territorio, 2008, pág. 50).

Planear implica reconocer la situación actual y la situación meta y trazar un camino para transitar entre estas dos situaciones. Es por tanto entendible que la toma de decisiones y las estrategias dependan de lo establecido para el recorrido de este camino a seguir, entendiendo que para esta tarea se deban estimar las posturas y los recursos con los que se cuenten para lograr nuestro propósito.

Para continuar adecuadamente, debemos aclarar también que existen diferentes paradigmas de planificación y que de estos hemos tomado uno, como marco para nuestra labor ya que encontramos que responde claramente con nuestros ideales.

La planificación con enfoque normativo, la planificación estratégico-situacional y la planificación con enfoque comunicativo son las referencias que contemplaremos en este abanico para reconocer las razones de nuestra elección de una de ellas sobre las otras.

La primera, de enfoque normativo, es la que asume una epistemología positivista, estimando una linealidad determinista y causal. Esta toma a la realidad como un objeto homogéneo y cosificado con fracciones independientes, regidas por leyes susceptibles de ser intervenidas en busca de eficiencia. La segunda considera que no hay una realidad social homogénea, y parte desde la identificación de problemas presentes para los actores de esas realidades y el posicionamiento de estos, es de ahí desde donde el planificador reconoce problemas sociales para los cuales se planifica. La tercera, la planificación con enfoque comunicacional, es la que tomamos como referente ya que a diferencia de las dos anteriores no tiene a un planificador ajeno a la realidad social, sino que éste se encuentra inmerso en sus dinámicas y no se plantea la planificación desde afuera. Estima la realidad como constituida por la integridad de su complejidad y dinamismo fruto de identidades propias de cada participante de ese entramado de la realidad, desde donde se reconocen miradas diferentes que construyen proyectos colectivos en cooperación y consenso, mostrándose de acuerdo en que priman los puntos de encuentro por sobre los de desencuentro para cimentar comunidad. 
"Para este modelo la planificación no es un instrumento sino un proceso de transformación de las relaciones sociales- comunicativas. Los proyectos y programas integran acciones y relaciones que se centran en los consensos de los actores involucrados. No existe una sola metodología, la planificación es un proceso de gestión que construye diferentes métodos en relación a la realidad y a los sujetos con los que se interviene." (Ceraso, Redes de Desarrollo Local y Colectivos de Comunicación en el Territorio, 2008, pág. 52).

Además, debemos tener en cuenta que el efecto de la planificación y la racionalización de las acciones que de ella se desprende, tiene resonancia en cómo interpretamos la realidad y las proyecciones que esperamos para esta, en relación a este tema Ceraso (Ceraso, Redes de Desarrollo Local y Colectivos de Comunicación en el Territorio, 2008) nos aclara acerca de la correspondencia de la planificación y su propósito en la acción transformadora: "Desde nuestra perspectiva, los procesos de planificación y gestión de proyectos, son instancias de producción de saberes sobre la propia realidad. La metodología nos permite una reflexión epistemológica y un posicionamiento político en la acción transformadora.” Pag 53

\section{Tomando acción}

El paso consiguiente a la planeación es la acción de la gestión, es el movimiento derivado de lo que se espera se dé para lo planeado. El llevar a cabo es lo que materializa los planos del proyecto. Es la acción racionalizada, es volver realidad lo meditado. Y por tanto, es acá donde se marca la diferencia entre soñar y materializar. Grandes aportes a los social no han pasado de la tinta en una hoja de papel, o, en otros casos, por la prisa del hacer se desestima el paso previo del planear. El juego entre la planeación y la gestión son los que crean una adecuada articulación de los proyectos. Esta búsqueda del equilibrio nos ayuda a reducir las dificultades inesperadas en los escenarios de intervención.

El ejercicio de la acción viene mediada y a su vez media los componentes de su alreded or, los participantes, los recursos, los tiempos.

... pensamos la gestión en sentido amplio. Nos referimos a la definición de criterios para la toma de decisiones en la ejecución de proyectos que, articulados entre sí, generen procesos de transformación de los problemas de nuestra realidad.

Cuando hablamos de gestión en un sentido más restringido, nos referimos a "la forma a través de la cual un grupo establece objetivos comunes, organiza, articula y proyecta las fuerzas y los recursos humanos, técnicos y económicos para alcanzarlos”. (Ceraso, 
Arrúa, \& Retola, Sembrando mi tierra de futuro., 2007, pág. 130).

Esta etapa del proceso aclara la naturaleza del hacer haciendo, en donde el propio ejercicio del hacer va impregnando de los propósitos de las actividades. Va generando esa memoria de lo trabajado en los actores, va haciendo notorio en el espacio tiempo usado y transitado, va dando cuenta de lo real de lo llevado a cabo, ahí es cuando se reconoce que la planificación y la gestión no son meros soportes de estantería instrumental, sino que, muy al contrario, son parte de los interventores de los proyectos.

El Carnavalito por la vida y el amor, se impregna de estos principios y determina por su propia fuerza de arrastre a que los ejercicios derivados de él mismo tengan la misma naturaleza, en otras palabras, se imprime una guía a la que seguir. La iniciativa de inclusión y participación es una clara invitación a entender que el propósito de los ejercicios es el de escuchar las voces emergentes del territorio y que estas aporten sus impresiones en la planeación y que los mismos partícipes de estos espacios lleven a cabo las acciones necesarias en la búsqueda de los deseos de los integrantes de la comunidad alrededor del Carnavalito. Pero, no es el propósito ultimo esperar a que se realicen los productos proyectados, sino tomar conciencia del proceso llevado a cabo y que los saberes fruto del ejercicio se integren a los saberes propios de cada integrante de la comunidad, de esta forma es que las caravanas, la integración de los niños y las madres comunitarias además de otros integrantes de la comunidad misma, cuenten con la experiencia de lo planeado y lo ejecutado. Las reuniones en las que se proyecta la temática del Carnavalito que se planea por venir y el paso a paso de este plano hasta su ejecución son parte de la formación que se da en el territorio, no es la caravana del ultimo día, es toda la fuerza alrededor de éste.

\section{Comunicación}

La consecuencia de estimar que toda disciplina que pretendiera ser ciencia tuviese que apegarse a la normativa positivista de Comte, devino más adelante en la formación de escuelas con enfoque lineal, con ansias de control sobre los objetos de estudio, un ejemplo es el de la teoría matemática de la comunicación. Esta escuela presenta un organigrama en el que se tiene a un emisor, un canal y un receptor que se entrelazan en relación a un mensaje. Esta secuencia rígida da cuenta de esa búsqueda de control y eficiencia que pretendían las disciplinas alrededor de esa primera mitad del siglo XX. Una estructura unid ireccional que ubicaba a un emisor activo y un receptor pasivo ante los mensajes emitidos.

Esta situación, ya desde el enfoque funcionalista de la comunicación, replantearía la postura de los sujetos participantes de este proceso y reconocería el contexto grupal en el que 
se encuentra inmerso el sujeto. Un sistema entramado de normas grupales entraba en juego al momento de interpretar los mensajes emitidos dentro del grupo y las correspondientes consecuencias de estas.

En la Teoría Crítica de la Comunicación, ya se le reconoce y se le asigna un papel dentro de la función política y social a los sujetos participes del entramado comunicacional, quienes ahora se podían revestir de motivaciones y de impulsos particulares que podían hacer que se reconocieran en ellos sus ideologías específicas, que conllevaban a posturas y estrategias como la manipulación; llevando entonces el estudio comunicacional al campo de la evaluación y la crítica cultural y de la sociedad. Reconociendo los aportes en la formación de estas escuelas de intercambio teórico, con estudios sociológicos, observamos que para Erving Gofman estas dinámicas comunicacionales trascienden el campo meramente estructural de los análisis de los enfoques iniciales de la comunicación y coloca el acto comunicativo en un escenario más orgánico:

Para Goffman, por ejemplo, las prácticas comunicativas son más hechos sociales que hechos de lengua (esto quiere decir que el lenguaje es un ideal lingüístico toda vez que al momento de expresar un enunciado éste ocurre de manera espontánea, sin una revisión rigurosa de su correcta estructura gramatical, lo que lo convierte sin importar su correcta organización una vez enunciado en un hecho social) y pueden ocurrir en cualquier momento como una metáfora teatral en la que los participantes asumen roles, bajo la dinámica de una interacción comunicativa en donde se da producción de sentido. (Flórez, 2019, pág. 49).

Pero, trascendiendo estas instancias más centradas en su componente epistemológico, y con la guía de Mario Kaplún, podemos pasar a observar la importancia de reconocer a la comunicación y su relación con la educación en un escenario más presto al cambio, a la transformación misma, ya que sus enseñanzas fueron definidas como las que planteaban una comunicación transformadora por sobre una educación bancaria. Esta definición dada para el esquema educativo basado en los contenidos, fue acuñada por el mismo Paulo Freire, se entiende de esta manera, ya que se fomenta una educación acumuladora de datos, en donde el educador consigna información en la mente del educando. De manera vertical y unidireccional vemos un juego de roles y jerarquías en este modelo de educación bastante tradicional en contextos como el latinoamericano, acerca de este tipo de escuela el mismo Kaplún menciona "Repetidamente se ha reprochado a la escuela tradicional su tendencia a confundir la auténtica educación con lo que es mera instrucción, con lo cual — se ha dicho también - ella INFORMA pero NO FORMA.” (Kaplún, 1998, pág. 22). 
Un educando sumiso y presto a la instrucción de un educador, establecido como el dueño de la verdad, quien es el que establece las reglas y demás normas a regir en el espacio de formación, una representación casi de caricatura del reflejo de los regímenes autoritarios, donde las minorías con poder están al mando de las minorías de las cuales solo se espera que se apeguen a la memorización de la instrucción sin cuestionarla. No es para nada sorpresa que este tipo de esquema educativo encuentre su símil en la teoría matemática de la comunicación. La unidireccionalidad, la voz en una sola punta de la línea del recorrido de un mensaje cargado de imposición para un receptor sumiso y sin voz, son los parangones que con evidencia emparejan estas posturas.

En la educación con énfasis en los efectos, observamos que toman a la formación como una estrategia de moldeamiento de la conducta, buscando establecer rutas definidas para fines que, según sus creadores, fueran más prácticos, fueran los esperados. Una producción en serie, eficaz y rápida es la directiva que se estima para este tipo de enfoques educativos. Un condicionamiento, un moldeamiento presto para la instrucción militar es lo que se ve en esta estructura. La comunicación persuasiva es la que se refleja en este tipo de formación. Una comunicación que busca desviar a conveniencia la direccionalidad del educando o receptor, del que ahora se reconoce, a diferencia del enfoque en los contenidos, puede tener un desacuerdo o una resistencia llevada al emisor en forma de retroalimentación o feedback, pero, al que se le busca reorientar esa resistencia hacia la meta deseada por el instructor. Se puede definir a este tipo de educación y comunicación como las de estrategias manipuladoras.

Para este modelo, comunicar es imponer conductas, lograr acatamiento. En tal contexto, la retroalimentación es tan sólo la comprobación o confirmación del efecto previsto (es decir, la «reacción del sujeto» ante la «propuesta»o «intento de comunicación»). Ella puede ser positiva si el individuo acata la propuesta o negativa si la rechaza. En este último caso, le sirve al emisor como instrumento de verificación y control: puede ajustar los próximos mensajes, regularlos, hacerles los cambios formales requeridos para, ahora sí, obtener el efecto prefijado, la respuesta deseada. (Kaplún, 1998, pág. 42).

En otras palabras, la presencia de la retroalimentación no es para reconocer la voz del receptor sino para saber si este ha aceptado la instrucción o qué tan distante está de esta.

Ya en el modelo educativo enfocado en el proceso, vemos el interés en la reflexión. Un modelo centrado en la persona, a quien Freire llamaría educación transformadora, liberadora. La ruptura con esos modelos unidireccionales e impositivos abre las puertas a nuevas miradas sobre la educación y sobre los sujetos participantes de esta. Se reconoce a un docente que 
aprende y a un estudiante con saberes también formadores. Una toma de conciencia crítica, una cosmovisión de su lugar y su tiempo es lo que se espera de este enfoque. En este enfoque se busca que el sujeto se piense dentro de la realidad que los rodea.

Ahora bien, este tipo de estructuras no invalida la orientación del profesor en el proceso formativo ni pone los aportes del educando como la nueva verdad, no, lo que se hace es que se rompen las posturas extremas en donde uno administra y el otro obedece. Pero, el objetivo principal de este enfoque no es ese, el verdadero propósito está en que se aprecie el camino recorrido en esa formación, donde se aprehenda del ejercicio, no porque se acumulen datos, ni porque se moldeen conductas sino donde se tome conciencia de la propia estructura y se piense a sí mismo.

Una comunicación dialógica, horizontal, es la que casa perfectamente con esta orientación. Una comunicación centrada en la construcción social, que a pesar de enfocarse en el proceso del sujeto, busca construir comunidad al sacarlo de la pasividad vista en otros modelos y posicionarlo como un sujeto de derechos y criterios, que cuenta con un amplio abanico de recursos que aporten a la transformación de su realidad a través de intercambios solidarios de experiencias y saberes.

Ahora bien, en una clara armonía con lo que se ha planteado en el presente documento, podríamos afirmar que es evidente que lo que se desea en el ejercicio del Carnavalito es generar un discurso horizontal en la comunidad. Un discurso que busca romper con esas imposiciones del miedo y la desidia, que empujan a la comunidad a segregarse en fracciones aisladas de todo. Al tomarse las calles y romper con esquemas impositivos el territorio se define como un espacio dialógico y por ende formativo. Un espacio presto a la transformación positiva, a través de los aportes de los integrantes del propio territorio. Un espacio tomado por las opiniones diversas que rompen con una comunidad llevada al silencio. Se ofrece una invitación a participar de la iniciativa, donde se reconocen los esfuerzos y el tránsito de los integrantes de las actividades. Donde se reciben los aportes y se aprecian los errores como momentos de problematización de una situación que devenga en un crecimiento. En otras palabras, se cuenta con una comunicación transformadora y constructiva.

\section{Comunicación audiovisual}

La interfase que hemos tenido los humanos con instrumentos de audio o de la línea visual creados por nosotros mismos no empezó con la última ola tecnológica, esta viene de mucho antes. El arte pictórico es el perfecto ejemplo de cómo una creación humana se vuelve 
un instrumento cargado de significados. Pero, cuando observamos la actualidad de este proceso podemos ver que la comunicación audiovisual se sustenta en plataformas mucho más tecnificadas, que necesitan de unas herramientas de alto diseño, que han facilitado el desplazamiento de los actos comunicativos por grandes distancias y en tiempos muy cortos, en la actualidad casi que inmediatos. Pero, qué se puede concebir como comunicación audiovisual, entendiendo que no es en exclusiva el medio tecnológico el que define este campo.

Podemos decir que la comunicación audiovisual es el proceso de intercambio de información apoyado en plataformas e instrumentos tecnológicos, que hace uso de elementos de sonido y de audio para transmitir mensajes y que estos cuentan con lenguajes con múltiples códigos que pueden ser objeto de análisis de forma tanto aislada como en su interrelación (Grau Rebollo, 2002).

Con lo anterior, identificamos que es justamente éste el campo de interés de enfoques disciplinares como el de la antropología audiovisual, que reconoce estas producciones como textos de altísima pertinencia para la aproximación a la identidad de las culturas humanas en la actualidad.

Puede verse además que otros autores tratan de ser más puntuales en la definición y entienden que los instrumentos creados en la primera mitad del siglo XX son los que propiamente deberían denominarse como audiovisual y los que han sido de creaciones más recientes entrarían a ser reconocidos como de la línea audiovisual-multimedia (Martín Serrano, 1995).

Aislándonos de las distinciones de las divisiones, vamos a entender a la comunicación audiovisual como la interrelación entre sujetos a través de plataformas tecnológicas usando contenid os de audio y video, que transmiten contenidos que son de nuestro interés, en lo particular de este documento.

Complementando el marco de las producciones audiovisuales, Jesús Martín-Barbero, reconoce que en las producciones mediáticas se producen mediaciones que materializan la institucionalidad y el espesor de la cultura de un pueblo. Lo anterior en la medida en la que la comunidad se encuentre reflejada en los contenidos mostrados en estos dispositivos. Él usa brillantemente el ejemplo de los comienzos del siglo XX del cine mexicano y la radio en Colombia: "El cine en algunos países y la radio en casi todos proporcionaron a las gentes de las diferentes regiones y provincias una primera vivencia cotidiana de la Nación" (MartínBarbero, 1991, pág. 179), ya que con estas producciones, se dieron a conocer las diferentes voces de territorios ajenos a los propios de los habitantes de las regiones. 
... antes de la aparición y difusión nacional de la radio el país era un rompecabezas de regiones altamente encerradas en sí mismas. Colombia podía llamarse antes de 1940 más un país de países que una Nación. Con los reparos del caso la radiodifusión permitió vivenciar una unidad nacional invisible, una identidad "cultural" compartida simultáneamente por los costeños, los paisas, los pastusos, los santandereanos y los cachacos. (Martín-Barbero, 1991, pág. 179)

Además de expandir las voces de los espacios distantes, estas producciones se empezaron a situar en un lugar orientador ya que se revestían como los íconos de las manifestaciones socioculturales.

La razón generativa del éxito fue estructural, vital; en el cine este público vio la posibilidad de experimentar, de adoptar nuevos hábitos y de ver reiterados (y dramatizados con las voces que le gustaría tener y oír) códigos de costumbres. No se accedió al cine a soñar: se fue a aprender. A través de los estilos de los artistas o de los géneros de moda el público se fue reconociendo y transformando, se apaciguó, se resignó y se encumbró secretamente. (Martín-Barbero, 1991, pág. 180)

Ahora bien, esta mediación no se presentaba propiamente porque hubiese un vacío cultural o porque la población careciera de una identidad propia, no, es porque se buscaba validar esa representación de las comunalidades de una Nación a través de los ideales reconocidos por la misma población en las producciones mediáticas.

El cine media vital y socialmente en la constitución de esa nueva experiencia cultural, que es la popular urbana: él va a ser su primer "lenguaje". Más allá de lo reaccionario de los contenid os y de los esquematismos de forma, el cine va a conectar con el hambre de las masas por hacerse visibles socialmente. (Martín-Barbero, 1991, pág. 181)

En otras palabras, los pueblos de las naciones encontraron en las producciones mediáticas la forma de escucharse en conjunto para consensuar una voz a la cuál seguir, eso es autoconstrucción por autorreconocimiento.

Este autorreconocimiento es la meta pretendida en la producción de los contenidos de los Talleres de Memoria en Video. Buscamos que la población se reconozca por su propia voz y que esta se materialice en esos contenidos audiovisuales autogestados para apoyar los procesos que fortalezcan esa identidad comunitaria en la comunidad alrededor del Carnavalito. Al reconocer los contenidos como voz propia y al ubicarlos en un lugar de consulta para fortalecer los procesos de los habitantes del territorio, damos espacio a esa 
trascendentabilidad temporal que dará lugar a esa memoria colectiva buscada; esta será entonces la memoria compilada en una dimensión de comunicación audiovisual.

\section{Carnaval y Carnavalito}

Las manifestaciones de fiestas populares en el formato de carnaval, en los diferentes pueblos y a través de diferentes épocas, han sido la forma en la que las comunidades exponen elementos que son parte de las identidades culturales propias de las regiones y de herencias ancestrales, entremezcladas en rituales de sus tradiciones, que invitan a la fraternidad y al fortalecimiento de esa misma identidad. Estas manifestaciones forman parte de un movimiento social que se reviste de sentidos, representaciones y significaciones de las comunidades, que tienen en esta manifestación un espacio para liberar deseos y exponer sus imaginarios y que así mismo, el movimiento propio de su alcance, desencadene en una poderosa influencia en la comunidad misma, a modo de retroalimentación.

La participación de los colectivos, al igual que los particulares, genera una relación de intersubjetividades, pero bajo el cobijo de unas pautas del comportamiento que transgred en lo usual, en donde se presenta la oportunidad de asumir roles y estéticas impulsadas por el ambiente de jolgorio y festividad. Los imaginarios materializados en estas expresiones, suelen ir enmarcados en manifestaciones artísticas que estilizan las representaciones religiosas, míticas, históricas, políticas, como formas de alegorías a la celebración superlativa o crítica, remarcando una visión diferente de las realidades en las que los participantes de las caravanas están inmersos.

Estas características particulares, adecuadas al territorio de los barrios del sur de Bogotá, han hecho que se adapten los deseos e intereses de cambio de los imaginarios y sentidos de los integrantes de esta comunidad. Para, de esta manera, posicionar mensajes claros de apropiación colectiva de sus espacios propios y reafirmar políticamente a grupos que antes habían sido llevados al silencio, por otros grupos escudados en la violencia, tanto directa como esa violencia estructural, esa que es invisible al ojo pero que se materializa a través de sus efectos residuales.

La denominación de Carnavalito no se da como forma de marcar un diminutivo por las dimensiones de esta manifestación popular en Ciudad Bolívar, sino porque los actores principales de este ejercicio son los niños y niñas, poniendo de nuevo sobre la mesa el interés de los gestores comunitarios por proyectarse hacia futuras generaciones, como la meta principal del colectivo. 
Un espacio para la celebración popular, para emancipar la cotidianidad, para extrovertir las emociones, es el que brindan las manifestaciones de la fiesta popular y con esto podemos afirmar que el incluir a la infancia del territorio en una fiesta es una de las maneras más adecuadas para orientar a esas nuevas generaciones en la apropiación de un territorio dentro de su propia historia. La vinculación mental de manera positiva con un espacio, crea arraigo y este genera una voluntad de cuidado por ese lugar de propiedad emocional y así es que las futuras generaciones contribuyen a la formación de esas identidades positivas de una comunidad y su territorio.

Acerca de esas construcciones positivas emergentes de las fiestas populares German Zarama (Zarama Vásquez, 2011) afirma los siguiente:

La Fiesta muestra la cara alegre y agradable de la sociedad. Fomenta su cultura tradicional y es la medicina emocional que crea cultura de paz en la misma colectividad.

En la Fiesta se da licencia para que salgan a flote sentimientos e imaginarios reprimidos durante el año. Allí se priorizan los valores y las expresiones emocionales esenciales del ser humano, reivindicando la alegría, afirmando la vida y convocando la energía del amor.

El escenario emocional y afectivo es fundamental en la celebración del ritual festivo, para recrear y regenerar la convivencia social. Se puede decir que "los pueblos vuelven a nacer" y reafirman sus valores, sentimientos, sentidos de convivencia y significados de existencia". Pag 6

Una celebración de la comunidad es un organismo vivo, cambiante, dinámico y por tanto se tiene que alimentar y oxigenar; esta vida insuflada por los integrantes de la comunidad es portadora de una identidad particular, es por esto que se debe pensar en una adecuada orientación para la misma ya que esta condensa su propia voz y con esta transmite mensaje en su territorio. Pensar la fiesta, planearla, anticiparla, es la forma en la que se busca darle un contenido a esa voz de las celebraciones. La voz que porta El Carnavalito por la vida y el amor es una que transmite apropiación de territorio, deseo de transformación, empoderamiento y una fuerte proyección hacia las futuras generaciones. Transmitiendo estos mensajes a través de los procesos, del color, de las actividades, emociones y de sus renovaciones año a año para entender esa actualidad de la comunidad. 


\section{Propuesta Metodológica}

\section{Diagnóstico comunicacional}

En la primera parte de la aproximación, se estableció un prediagnóstico y un diagnóstico de la situación actual del Carnavalito y de cada uno de los grupos que participan de su desarrollo, en estos buscamos definir cuáles fueron los gestores a los que se entrevistó y con qué comunidades se trabajó (Ceraso, Arrúa, \& Retola, Sembrando mi tierra de futuro., 2007). Con estos gestores se desarrollaron entrevistas semiestructuradas, se recopilaron las entrevistas en formatos audiovisuales, se compilaron observaciones en campo. Todo lo anterior para aproximarnos a qué aspectos son positivos y cuáles no lo son en relación a las expectativas del Carnavalito. Se acudió en mayor medida a las fuentes testimoniales de la comunidad, relacionadas con las prácticas sociales y los valores subjetivos que giran en torno al Carnavalito y su propósito.

\section{Análisis del diagnóstico y diseño de líneas de acción}

Una vez reconocidos los procesos comunicacionales de los diferentes grupos participantes y gestores del Carnavalito, se determinó cuáles son las expectativas y se buscó desarrollarlas a través de experiencias propias de la comunidad con las que se iniciará la construcción de la memoria audiovisual que consolide las narrativas de su identidad comunitaria. Se acordó con la comunidad qué líderes participarían de los talleres de reconocimiento reflexivo de identidad comunitaria y formación en herramientas y técnicas de producción audiovisual.

Se desarrolló con los líderes unas entregas de contenidos audiovisuales de experiencias de la comunidad, a modo de ejercicio práctico para presentar a la comunidad en general y para que sirvan de guía y se replique el ejercicio con otros integrantes de la zona, buscando encausar los deseos de la comunidad y fortalecer las dinámicas de los procesos comunitarios.

\section{Redacción de la Tesis}

Redacción del documento donde se consigna toda la experiencia, reflexiones, aportes y conclusiones a la práctica desde la mirada PLANGESCO.

\section{Reflexiones del proceso con la comunidad.}

Conversatorio de socialización y reflexiones finales del proceso de la tesis. Entrega de los aportes y productos audiovisuales. 


\section{Metodología Etnográfica}

Esta aproximación metodológica pertenece a la línea fenomenológica, en la que prima el punto de vista del sujeto evaluado, su impresión del fenómeno. Esta postura entra en diálogo perfecto con la estructura teórica propuesta para este documento y por tanto es altamente provechosa para los objetivos del mismo. Este enfoque cualitativo entra en la línea de lo que buscamos que es la aproximación a la comunidad de forma que se reconozcan sus opiniones de primera mano.

Es clave precisar que cuando se habla de etnografía se pueden dar a entender tres cosas diferentes que en ocasiones se conciben como sinónimos y se prestan para confusiones, pues también se puede creer que la etnografía necesaria mente aborda las tres dimensiones y no es así. Por tanto, se debe aclarar qué es cada una de ellas: la etnografía como técnica de investigación, la etnografía como metodología y la etnografía como método. Para la técnica entendemos que esta es una herramienta o instrumento que busca aplicarse para la producción de datos. Para la metodología y método Eduardo Restrepo en su libro Etnografía: alcances, técnicas y éticas, aclara los detalles de cada una de ellas:

La metodología es la manera particular en que se operacionalizan ciertas técnicas de investigación y cómo se articulan consistentemente varias de ellas en función de una pregunta o problema de investigación; por lo tanto, la metodología apunta a sustentar el cómo se realiza la investigación. El método, por su parte, tiene que ver con una discusión más amplia que articula las convicciones que llevan al investigador a resolver su investigación de la manera en que decidió hacerlo. De cierta manera, la discusión que supone el método no es tanto por la elección de las técnicas utilizadas sino que es de carácter epistemológico: refiere al porqué del cómo, esto es, sustentar persuasivamente las razones que articulan coherentemente los presupuestos teóricos y conceptuales de la investigación con la metodología que se diseñó (Restrepo E. , 2016, pág. 32).

La etnografía como metodología, entendida como un encuadre, es la que usaremos en nuestra aproximación ya que utilizaremos otros instrumentos que serán cobijados por esta amplia metodología y que servirá de guía y compiladora de los resultados generales.

Acá, daremos uso de la metodología etnográfica de tipo procesal funcional (Boyle, 2003) que nos ayuda con técnicas para abordar el territorio de forma adecuada en relación a lo esperado por esta intervención. Utilizaremos las etapas establecidas por este método y serán descritas por los siguientes pasos: 
1. Selección del diseño: qué quiero estudiar, cuál es mi objetivo, cuál es el método que más se adapta (Boyle, 2003).

2. Determinación de las técnicas: las que más se usan son la observación (participante) y la entrevista (Guber, 2001).

3. Acceso al ámbito de investigación: escenario al que se busca acceder (se debe tener contacto anticipado con uno de los miembros de la comunidad. En lo posible que sea un miembro resaltable) (Boyle, 2003).

4. Selección de informantes: es esperable que se busque a informantes destacados y que el investigador se proyecte dentro de los intereses y formas de estos para que de esta forma asimile de mejor manera el contexto a evaluar (Restrepo E. , 2016), (Guber, 2001).

5. Recogida de datos y determinación de la estancia en el escenario: portafolio de todos los registros llevados a cabo en la investigación. Todos los formatos (Entrevistas, escritos, grabaciones, videos, fotografías, notas de campo, cuestionarios) (Boyle, 2003), (Restrepo E., 2016).

6. Procesamiento de la información: compilación de todo el portafolio y su análisis (aunque este se puede llevar a cabo durante la aproximación y no solo al final de esta) (Boyle, 2003), (Restrepo E. , 2016).

7. Elaboración del informe: Es acá donde hacemos acotaciones descriptivas de lo encontrado; después enlazamos lo encontrado con las bases teóricas y empíricas; continuamos con la descripción de la experiencia para los actores involucrados y finalizamos con aquellos resultados destacables que puedan contribuir a la teoría (Guber, 2001), (Restrepo E. , 2016).

\section{Instrumentos}

\section{Observación participante}

La inmersión en el territorio es uno de los factores diferenciales de metodologías como la etnográfica que busca, a través de técnicas como la observación participante, reconocer de primera mano las impresiones de los grupos sociales que son el objeto de estudio de aproximaciones investigativas como la que interesa al proceso que fue llevado a cabo y que se plantea en este documento.

Tradicionalmente, el objetivo de la observación participante ha sido detectar las situaciones en que se expresan y generan los universos culturales y sociales en su compleja articulación y variedad. La aplicación de esta técnica, o mejor dicho, 
conceptualizar actividades tan disímiles como "una técnica" para obtener información supone que la presencia (la percepción y experiencia directas) ante los hechos de la vida cotidiana de la población garantiza la confiabilidad de los datos recogidos y el aprendizaje de los sentidos que subyacen a dichas actividades (Guber, 2001, pág. 52).

Para esto tenemos que seguir unos pasos, aunque no es una secuencia rígida y obligatoria.

1. Entrada en el campo: contacto y empalme con informantes clave.

2. Tácticas en el campo: integrarse sin irrumpir en la comunidad, conservar un bajo perfil, rappor, establecer preguntas claras para buscar resolverlas en la actividad del campo, familiarizarse con el grupo y sus códigos.

3. Instrumentos: notas de campo, grabaciones etc., en donde registramos y describimos los lugares, las actividades, los actores y los discursos de la comunidad. Además, se registran las observaciones y acciones del observador, también las cosas que se le dificulta entender.

4. Retirada del campo: Saturación de datos o saturación teórica. El momento en que el investigador asuma una redundancia de información que dé pie para iniciar el cierre de la aproximación.

\section{Entrevista etnográfica}

Es un tipo de entrevista particular que gira en torno al objetivo de una investigación puntual. Esta se prepara para personas específicas y claves de la comunidad. Aunque se deben preparar las preguntas, estas tienden a ser abiertas para dar lugar a que el entrevistado tenga libres respuestas y no se sesguen estas desde el planteamiento del entrevistador; con esto se marca una distancia de los test, los cuestionarios y las encuestas con los que pueden llegar a confundirse. Se espera conocer de boca del entrevistado, cuáles son sus percepciones acerca de elementos puntuales que sugiere el entrevistador (Restrepo E. , 2016).

No es debido abordar al entrevistado con predisposiciones, ni prejuicios, ni con desconocimiento de él en su vida, ni de su comunidad. Es debido afrontar estos espacios de manera horizontal sin imposiciones y tomando en cuenta el lenguaje y los códigos que se manejen en la cotidianidad del territorio (Guber, 2001). 


\section{CAPITULO 2}

\section{Mi proceso. Unas comillas aparte}

Empezar a familiarizarse con los barrios para diagnosticar el territorio, no es sólo memorizarse los datos que lo describan sino sentir cercanas las calles, ubicar los lugares, reconocer los espacios cuand o se habla de ellos en las conversaciones sueltas. Es mirar que hay una tienda nueva donde hace años había otra cosa, es mirar que los vecinos han puesto más pisos a sus casas. Es sentir familiar el saludo de las personas con las que después de un tiempo se vuelve habitual el verse.

Poder sentarse a almorzar en los espacios de los sancochos, previos a la caravana del Carnavalito, es cruzar los telones que hay detrás del evento de la fiesta popular y adentrarse en el motivador inicial que es la fuente y el fin último, que es la comunidad gestora, es la comunidad activa y política, es la comunidad humana, es el comentario fraternal entre las lideresas que llegan saludando a sus compañeras, es escuchar las anécd otas de años anteriores de cómo pudieron sobrellevar alguna dificultad y salir adelante con la fiesta popular. Es tener invitación a la fiesta pero también es saber cómo se hace, es saber que la marcha por las calles del barrio sólo es la punta del iceberg de la verdadera transformación que se está gestando desde las personas que se sientan en una terraza a compartir una comida.

\section{Llegar al territorio, acercarnos al problema}

El abandono estatal en diferentes zonas de Colombia no es ajeno en la capital de la república. La falta de una fuerza de seguridad que resguarde a la población en los cinturones de la ciudad, ha fomentado el poderío de grupos privados y sombríos, que con sus discursos y estrategias violentas buscan acallar lo que no entra en sus fronteras de tolerancia (Rojas Gomez, 2011). Los asesinatos selectivos perpetrados por estos grupos al margen de la ley han generado desconcierto en la población y la consecuente desidia y desvinculación del territorio por gran parte de la comunidad. Motivados por el valor, varios de los grupos de vecinos a cargo de iniciativas comunitarias de la zona, se han reunido para generar un espacio de representación popular denominado El Carnavalito por la vida y el amor.

El Carnavalito, como expresión popular, nació teniendo como propósitos manifestar una voz de protesta ante la presentación de los asesinatos selectivos en el territorio y mostrarse como un escenario para la vinculación de la comunidad; es una manifestación 
social en forma de caravana, donde se marcha por distintas rutas de la zona para llegar a un punto central, donde una tarima activa recibe los grupos de marchantes.

Aunque la tarea de producir el Carnavalito una vez por año sea ardua y continua, estos grupos de líderes zonales plantean siempre llegar a los habitantes del territorio promulgando valores potenciales para el fortalecimiento de la comunidad (Inti Tekoa, 2018). El fomentar esto se ha vuelto una tarea dependiente de cientos de personas y por tal razón se plantea la posibilidad de buscar hacer que esta iniciativa llegue a un espectro más amplio de población.

Una de las iniciativas para este acercamiento fue el definir cuáles son las posibles expectativas de los gestores de esta propuesta y reconocer cuál es el alcance actual de esta manifestación social. El estudio de estos elementos fue trabajado con aproximaciones de técnicas y disciplinas socio-humanistas, la etnografía, la entrevista, la observación participante, entre otras (Guber, 2001), (Boyle, 2003), (Restrepo E. , 2016), (Santander, 2011). Estas herramientas ayudaron a hacer claros estos vínculos colectivos esperados y proyectados, además ayudaron a dimensionar cuál es el punto actual del que se partió y cuál es la expectativa a la que se le apuntó al construir el proceso.

A través de diferentes formatos de la Psicología se buscó tener un potente instrumento para construir espacios comunitarios que favorezcan la igualdad social, el empoderamiento y un diálogo de saberes que desarrolle sujetos partícipes de su contexto, sujetos constructores, políticos y desarrolladores (Rowlands, 1997). Ahora bien, esos espacios no se dan esporádicamente, ni con la intervención de una sola disciplina, esto se tiene que gestionar a través del ejercicio de varias disciplinas y saberes con orientadores comunes (Montero, Hacer para transformar, 2006). La comunicación como proceso fundamental de la naturaleza es de vital importancia para todos los niveles de evaluación e intervención de las presentes inquietudes, por tanto, con el apoyo de estos instrumentos y constructos del conocimiento humano es que hemos buscado potencializar la iniciativa del Carnavalito.

Mediante el desarrollo de la cursada de la maestría en PLANIFICACIÓN Y GESTIÓN DE PROCESOS COMUNICACIONALES, de la Universidad Nacional de La Plata, se han venido evidenciando diferentes nod os temáticos alrededor de situaciones sociales actuales. Estas radiografías de nuestras comunidades y de las fuerzas que se ejercen en ellas han impulsado el deseo de respaldar a estas iniciativas que fomentan el desarrollo de diferentes grupos sociales, con principios como el de la construcción de sentidos, sobre una comunicación dialógica que busque un sujeto gestor de su propia comunidad, que genere cohesión y desarrollo comunitario. 
En la actualidad, la época de la hiperconectividad, no es difícil de sustentar que la difusión puede llegar mucho más lejos y puede llevar mucho más contenido que hace menos de un siglo. Es exponencialmente superior a lo que había sido jamás en la historia de la humanidad, por tanto, aprovechar los canales dispuestos para ayudar a la difusión es un elemento que en la actualidad es crucial. Reconociendo que el receptor de la información no es un receptor pasivo, se buscó que, en relación al impacto del Carnavalito, este receptor fuese partícipe de la construcción del mismo, por tanto, dimensionar al Carnavalito en plataformas como las audiovisuales lo que busca es encontrar nuevos horizontes de impacto y alcance. Hemos esperado que la divulgación en círculos fuera de la distancia territorial de la zona por la que se marcha en la caravana, pueda llegar a comunidades que se puedan identificar con la iniciativa y buscar sumarse a esta o replicarla en sus comunidades.

Claro está que para saber a dónde dirigir nuestras líneas de acción primero hemos establecido una puesta en común de los diferentes grupos comunitarios que intervienen en el evento, para que después pudiésemos aunar y sacar como resultado una postura conjunta. Además, se buscó tener acceso a la opinión de integrantes de la comunidad que estuviesen fuera de la actividad, buscando entender cuáles pueden ser las propuestas esperadas por los que no están vinculados pero que estarían dispuestos a serlo en un futuro.

\section{Contexto de la ciudad de Bogotá. Descripción del campo material}

Bogotá D.C. (Distrito Capital), es la ciudad capital de la república de Colombia. Es la ciudad más grande y poblada del país con una extensión de 1.775 kilómetros cuadrados y una población que para el 2019 se estima de más de 8’200.000 habitantes. Fundada el 6 de agosto de 1538. Actualmente dividida en 20 localidades. Interesándonos para el presente documento la localidad 19 Ciudad Bolívar, al sur de Bogotá, que cuenta con 682.861 habitantes. Las localidades a su vez se subdividen por UPZ (Unidades de Planeamiento Zonal). La localidad 19 se divide en 8 UPZ interesándonos en particular las UPZ 69 y 70 (Numero asignado por el total de UPZ de la ciudad) Ismael Perdomo y Jerusalén, respectivamente, ya que en estas se ubica el evento del Carnavalito. 


\section{Figura 3}

LA LOCALIDAD 19, CIUDAD BOLÍVAR A SU VEZ SE DIVIDE EN 8 UPZ

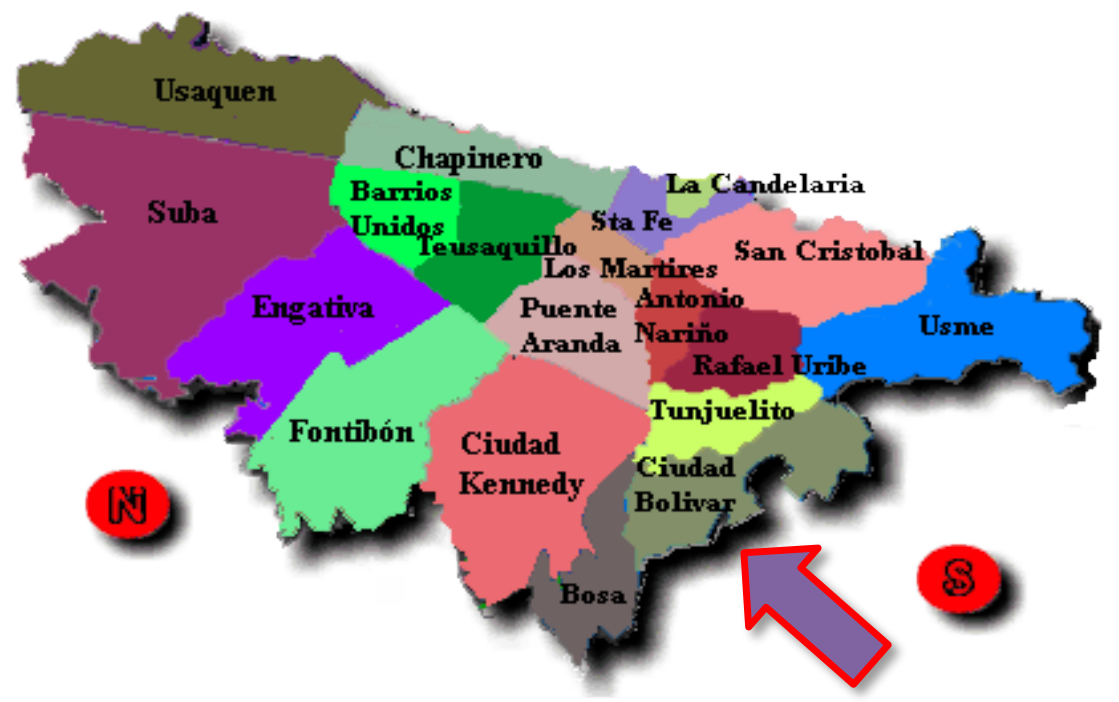

(Secretaría Distrital de Planeación, 2019). La flecha señala la zona donde se celebra el Carnavalito por la vida y el amor [flecha incluida por el autor].

\section{Figura 4}

MAPA CIUDAD BOLÍVAR, DIVISIÓN POR SUS 8 UPZ

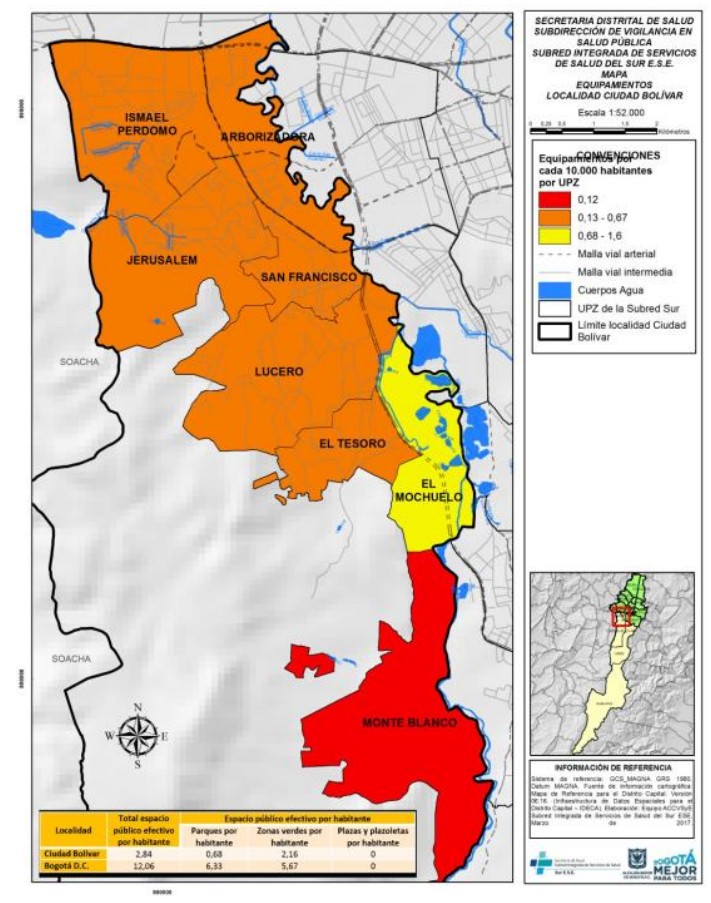

(Secretaría de Salud de Bogotá, 2017) 


\section{Estratificación}

Bogotá tiene una división socioeconómica determinada por estratos. Estos estratos son ubicaciones o márgenes que definen a las viviendas basándose en las condiciones en las que estas se compongan. De esta manera encontramos seis estratos que van del estrato 1, asignado a las viviendas más vulnerables (también dado a las propiedades de interés patrimonial como museos, etc.) hasta el estrato seis, asignado a las viviendas de más alto nivel de composición e inversión económica. Como es de entender las casas de un estrato bajo no se hacen al lado de casas de estrato alto, generando que finalmente esta estratificación pensada para definir viviendas termine definiendo las zonas, y así es que encontramos la división zonal de estratos de la ciudad (Secretaría Distrital de Planeación, 2019).

Para la localidad de Ciudad Bolívar encontramos que más del $85 \%$ de la población vive en zonas con estratos 1 y 2. Y dentro de esta localidad las UPZ 69 y 70, donde se ubican los barrios en donde se celebra el Carnavalito, la población en estratos 1 y 2 llega al 95\% (Secretaría de Salud de Bogotá, 2017).

\section{Figura 5}

MAPA DE BOGOTÁ DEMARCANDO LAS ZONAS ESTRATIFICADAS

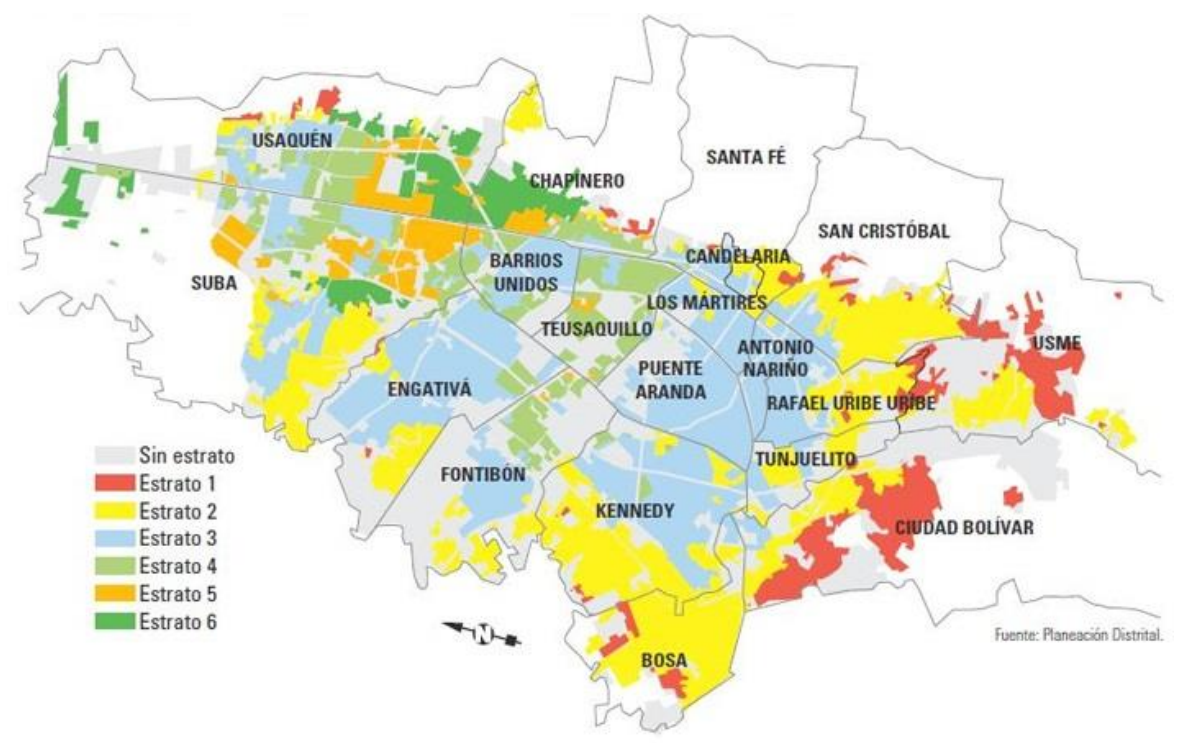

Fuente (Secretaría Distrital de Planeación, 2019) 


\section{Figura 6}

MAPA ESTRATIFICACIÓN DE CIUDAD BOLÍVAR.

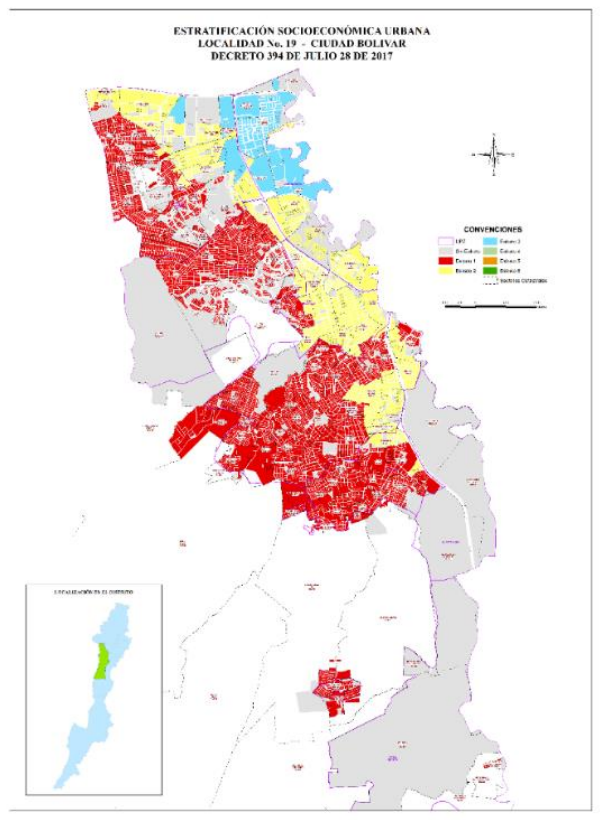

Fuente (Secretaría Distrital de Planeación, 2019)

Tabla 1

DIVISIÓN POR ESTRATOS EN BOGOTÁ

\begin{tabular}{lcl}
\hline Estrato & $\begin{array}{c}\text { Porcentaje de } \\
\text { población }\end{array}$ & \multicolumn{1}{c}{$\begin{array}{c}\text { Nivel } \\
\text { socioeconómico }\end{array}$} \\
\hline Estrato 1 & $7.1 \%$ & (bajo-bajo) \\
\hline Estrato 2 & $33.1 \%$ & (bajo) \\
\hline Estrato 3 & $34.3 \%$ & (medio-bajo) \\
\hline Estrato 4 & $16.2 \%$ & (medio) \\
\hline Estrato 5 & $5.2 \%$ & (medio-alto) \\
\hline Estrato 6 & $4.2 \%$ & (alto) \\
\hline
\end{tabular}

(Secretaría Distrital de Planeación, 2013)

\section{Crecimiento demográfico}

La población estimada para la ciudad de Bogotá en 2019 es de 8'200.000 habitantes, de los cuales según guía del CENSO realizado en 2005 menos del 60\% de la población bogotana es de personas nacidas en esta ciudad (DANE, 2015).

El crecimiento demográfico de Bogotá se da naturalmente por los nacimientos de sus nuevos ciudadanos en la ciudad, pero además por la migración en la mayoría desplazados por 
la violencia. Se estima que la migración por desplazamiento forzado corresponde al $35 \%$ del total del crecimiento general demográfico en la ciudad. Los migrantes por desplazamiento buscan la capital del país esperando que se tenga una mejor calidad de vida. Pero esta expectativa muchas veces se trastoca con choques culturales además de los políticos y económicos. La población desplazada muchas veces llega a la ciudad con sus hijos y familiares y no cuenta más que con lo que llevan puesto, este cuadro es descrito clara y tristemente en la película La primera noche, 2003, del director Luis Alberto Restrepo (Restrepo L. a., 2003). Estas precarias llegadas a la ciudad empujan a los nuevos habitantes de la ciudad a refugiarse en lugares poco seguros pero económicos, generalmente los cinturones de la ciudad.

La zona que más acoge población desplazada de todo el país es Bogotá, más puntualmente la localidad de Ciudad Bolívar, donde se encuentran las UPZ 69 y 70 (unidades de planeamiento zonal) Ismael Perdomo y Jerusalén. Estas UPZ tienen la tasa más alta de población que ha sido desplazada y es donde se realiza El Carnavalito (Cardona, 2016).

Pero este fenómeno de recepción de migrantes por desplazamiento no se presenta sólo en la ciudad de Bogotá, además está en el municipio de Soacha, aledaño a la ciudad y que no casualmente es el municipio que limita con la localidad de Ciudad Bolívar. Y no casualmente el Barrio los Robles, de Soacha, es el vecino contiguo al barrio Caracolí, donde se celebra El Carnavalito. Esto nos ayuda a entender el contexto en el que se construye la población objeto de este documento (Isaza, 2008).

La periferia de la ciudad se estereotipa muchas veces en términos de ruralidad, de retraso y marginalidad, un espacio para los salvajes, (Otalora, 2014). Etiquetas que van construyendo estigmas para los habitantes de estas zonas que llegan ahí a asumir roles ajenos a ellos, pero impuestos por la comunidad de la ciudad del centro, la ciudad vieja y que se adopta y replica muchas veces por los mismos habitantes de estos cinturones de ciudad.

\section{Tabla 2}

CRECIMIENTO DEMOGRÁFICO BOGOTÁ

\begin{tabular}{cc}
\hline \multicolumn{2}{c}{ Población histórica } \\
\hline $\mathbf{1 9 3 8}$ & 325650 \\
\hline $\mathbf{1 9 5 1}$ & 715250 \\
\hline $\mathbf{1 9 6 4}$ & 1697311 \\
\hline $\mathbf{1 9 7 3}$ & 2855065 \\
\hline
\end{tabular}




\begin{tabular}{ll}
\hline $\mathbf{1 9 8 5}$ & 4236490 \\
\hline $\mathbf{1 9 9 3}$ & 5484244 \\
\hline $\mathbf{2 0 0 5}$ & 6778691 \\
\hline $\mathbf{2 0 1 7}$ & 8081000 \\
\hline
\end{tabular}

(Secretaría Distrital de Planeación, 2019).

\section{El Carnavalito por la vida y el amor}

Este evento cultural que tuvo su primera versión en el año 2007, y que ininterrumpidamente se ha presentado una vez cada año desde entonces, en la actualidad consta de varias etapas que van desde su planeación anual, su ejecución y su evaluación.

En la planeación del evento se establecen las pautas para a la ejecución de este. Fecha, recorrido, agenda, presupuesto, entre otros, son los temas con los que se inician las reuniones en donde participan los diferentes grupos interesados en la realización del Carnavalito.

Las reuniones se realizan en lugares acordados por los grupos. Allí se distribuyen responsabilidades que se asignan con el común acuerdo de los participantes.

Previo al evento principal se realiza un $\operatorname{Sancocho}^{22}$ que es una reunión final para definir detalles últimos alrededor de un almuerzo compartido. El evento es generado con la donación de los víveres necesarios para la realización del sancocho y donde las personas alrededor de la producción del evento comparten un espacio distendido y jovial para que puedan interactuar de manera informal.

El Carnavalito, propiamente como evento principal, se divide a su vez en diferentes etapas. Comenzando con el encuentro y agrupación en los diferentes puntos de partida de la zona para después iniciar la salida de los marchantes en varios grupos por trazados diferentes que confluirán en el punto de llegada central. En la caravana los diferentes grupos llevan pancartas con frases referidas a las instituciones a las que están vinculados, a las iniciativas del Carnavalito, al tema que trabaje el Carnavalito ese año, saludos a la comunidad, etc. Con cánticos, arengas, presentaciones de bandas instrumentales de niños de la comunidad, familias, disfraces y mascotas.

A medida que se van congregando los grupos en el punto de llegada, estos van siendo recibidos y presentados desde la tarima principal. Ya en este punto se ubicarán según se haya acordado en la planeación. Una vez culminada la llegada de los marchantes se procede a la realización de las diversas presentaciones en la tarima principal.

\footnotetext{
${ }^{22}$ Un sancocho es un plato de la comida típica colombiana. Generalmente se dice que se va a hacer un sancocho cuando se refieren a una celebración alrededor de este plato como prin cipal a tractivo.
} 
Cantos, bailes, concursos, discursos, son parte de la jornada. Un saludo final después de ésta concluye el evento.

Tabla 3

EJEMPLO AGENDA DE TRABAJO CARNAVALITO

\begin{tabular}{|c|c|c|c|}
\hline Actividad & Hora & Responsables & Lugar \\
\hline $\begin{array}{l}\text { Encuentro grupo } \\
\text { logística }\end{array}$ & 07:00 & $\begin{array}{l}\text { Practicantes, } \\
\text { voluntarios y } \\
\text { miembros Inti Tekoa }\end{array}$ & Sede Inti Tekoa \\
\hline $\begin{array}{l}\text { Distribución por } \\
\text { lugares de apoyo }\end{array}$ & $07: 30$ & Fernando Cardona & Sede Inti Tekoa \\
\hline $\begin{array}{l}\text { Ubicación en sitios } \\
\text { de comparsa }\end{array}$ & 08:00 & $\begin{array}{l}\text { Líder de Inti Tekoa y } \\
\text { personas de apoyo } \\
\text { (Practicantes, } \\
\text { voluntarios) }\end{array}$ & $\begin{array}{l}\text { Puntos de salida: } \\
\text {-Sierra Morena } \\
\text {-Celodije } \\
\text {-Parque Santa Rosita } \\
\text {-Alameda Potosí } \\
\text {-La Y } \\
\text {-Caracolí }\end{array}$ \\
\hline $\begin{array}{l}\text { Ubicación en zona } \\
\text { de concentración }\end{array}$ & $07: 30$ & $\begin{array}{l}\text { Líder de Inti Tekoa y } \\
\text { personal de } \\
\text { apoyo (Practicantes, } \\
\text { voluntarios) }\end{array}$ & $\begin{array}{l}\text { Parque tanque } \\
\text { laguna. }\end{array}$ \\
\hline $\begin{array}{l}\text { Inicio de } \\
\text { comparsas }\end{array}$ & $08: 30$ & $\begin{array}{l}\text { Líder de Inti Tekoa y } \\
\text { personal de } \\
\text { apoyo (Practicantes, } \\
\text { voluntarios) }\end{array}$ & $\begin{array}{l}\text { Puntos de salida: } \\
\text {-Sierra Morena } \\
\text {-Celodije } \\
\text {-Parque Santa Rosita } \\
\text {-Alameda Potosí } \\
\text {-La Y } \\
\text {-Caracolí }\end{array}$ \\
\hline $\begin{array}{l}\text { Inicio de } \\
\text { presentaciones en } \\
\text { tarima }\end{array}$ & 09:30 & $\begin{array}{l}\text { Niñas y niños de } \\
\text { jardines, grupos } \\
\text { invitados }\end{array}$ & $\begin{array}{l}\text { Parque tanque } \\
\text { laguna }\end{array}$ \\
\hline
\end{tabular}

(Inti Tekoa, 2018).

Como parte de la evaluación, al culminar el evento se acuerda entre los gestores del Carnavalito, una reunión en donde se recogen las impresiones de los organizadores, recopilando los éxitos y los aspectos a mejorar.

\section{El Carnavalito por la vida y el amor en clave de paz}

Reconocer la intervención del Carnavalito en la cotidianidad del territorio de los barrios de las UPZ 69 y 70 de Ciudad Bolívar, conlleva el hacer evidente las implicaciones acerca del impacto que este tiene en dimensiones como la de la construcción de paz. 
La Construcción de Paz se centra principalmente en la transformación de las relaciones, para que paulatinamente los cambios se consoliden como parte de una cultura de paz y convivencia; la Fiesta municipal es la expresión de la cultura de un municipio, y en ella se reflejan los valores y sentidos que nuestra cultura le otorga a la paz y a la convivencia. Estas expresiones pueden ser percibidas a manera de claves que resuenan para conectar a las personas, o para dividir y generar tensión entre ellas. (Zarama Vásquez, 2011, pág. 31)

La tarea adelantada por los hacedores del Carnavalito comprende el habilitar espacios para la vinculación, el intercambio de saberes, además de la manifestación de las expresiones de los habitantes de los barrios de las UPZ 69 y 70, que son parte de la construcción de esa cultura de paz necesaria para el surgimiento de identidades comunitarias positivas para el territorio.

Consolidar una cultura de paz no es una labor dirigida única y exclusivamente a dar término a la violencia. Es también: Potenciar creencias, prácticas, costumbres, hábitos y patrones de relación que hayan contribuido al fortalecimiento de la convivencia pacífica en el municipio (Por ejemplo, la mayoría de las expresiones humanas asociadas a la creación artística colectiva unen o conectan a las personas desde sus emociones, motivaciones e intereses comunes). (Zarama Vásquez, 2011, pág. 32)

La procura por consolidar manifestaciones nacidas del territorio, gestadas por sus habitantes, también es una expresión de construcción de una cultura de paz, en la medida que incluye a las voces propias dentro de los relatos de la cotidianidad y de los acontecimientos que son parte de la historicidad colectiva. La constancia del Carnavalito como proceso de gestación endógena da cuenta de una expresión de construcción encaminada a la transformación, sustentada en una fiesta popular.

\section{Quiénes participan del Carnavalito}

Para describir a los actores que se encuentran alrededor del Carnavalito tenemos que dividirlos en varios grupos. Los Organizadores, los asistentes, los transeúntes y los patrocinadores.

\section{Los organizadores}

Son varias las organizaciones que están a cargo de la producción. La Corporación Inti Tekoa y las diversas asociaciones de madres comunitarias son parte fundamental de esta iniciativa. 


\section{Corporación Inti Tekoa}

Es una organización que nace como el resultado del acuerdo de un grupo de jóvenes de la comunidad del barrio Caracolí, como respuesta a la realidad en la que se encontraban inmersos y de la cual querían ser participantes y no solo observadores.

Estos jóvenes crecieron en esa comunidad viendo el desarrollo de la arquitectura y las costumbres de sus gentes y desde su propia iniciativa se agrupan con ideas de contribuir a su comunidad. De ahí que varias de sus ideas se volvieron programas encaminados a la construcción positiva de esta zona de la ciudad.

Tiene como lugar físico de encuentro la sede de la Corporación Inti Tekoa ubicada en El barrio Caracolí de la localidad de Ciudad Bolívar.

Sus miembros fundadores son:

- Dimelsa Agudelo

- Edison Aguirre

- Fernando Cardona Sánchez

- Miguel Castellanos

- Miller Jiménez

- Tatiana Murillo

- Viviana Gómez

\section{Madres comunitarias}

La figura de Madres Comunitarias en Colombia y particularmente en Bogotá nace como iniciativa de grupos de mujeres que toman la labor de cuidado y formación de niños de las comunidades en las que habitan, reconociendo la vulnerabilidad que podían tener estos niños y bajo un Estado ausente para estas necesidades. Historias tales como la de encontrar familias con una mujer cabeza de familia, que tiene que ir a trabajar y dejar a sus hijos desprotegidos por la necesidad de procurarles alimentación, fueron parte de lo que impulsó a la creación de las Madres Comunitarias que acogían estos niños en sus propias casas sin apoyo ni políticas que respaldaran su labor.

Estos centros de acompañamiento para niños o jardines infantiles se reúnen para formar asociaciones. Es así que varias asociaciones participan activamente, tanto en la organización como en la dinamización del Carnavalito.

Las asociaciones participantes son:

-Asociación Nuevos Horizontes

-Asociación El Ensueño 


\author{
-Asociación Paraíso \\ -Asociación Futuros de Colombia \\ -Asociación Caminito Alegre
}

\title{
Los asistentes
}

Generalmente los asistentes continuos de las jornadas son aquellos que son familiares o allegados a los organizadores y principalmente vinculados a las fundaciones que ejercen su labor en esta zona, pero también hay un número de particulares que son constantes a esta manifestación popular y se suman a la jornada.

Se tiene que resaltar la importante presencia de los niños y jóvenes ya que ellos son el punto central del interés de la propuesta que busca integrarlos a los procesos y cambios de la comunidad.

Algunos medios de comunicación locales se han hecho presentes en ediciones anteriores para cubrir la expresión cultural, al igual que unos cuantos curiosos que son bienvenidos.

\section{Los transeúntes}

En los diferentes trazados del recorrido, la caravana se va mostrando ante los habitantes de la zona que, con alguna frecuencia, no tienen claridad acerca de quiénes son ese grupo de personas marchando. Los habitantes de las casas próximas a las marchas se observan por puertas y ventanas acompañando con su mirada las calles llenas de marchantes.

\section{Los patrocinadores}

Una de las consignas de la iniciativa del Carnavalito es la independencia de organizaciones con intereses particulares. Partiendo de esto varias organizaciones han sumado sus aportes sin intervenir en los propósitos de los organizadores del evento.

En todas las ediciones del Carnavalito los principales aportantes, casi en la totalidad de los recursos, han sido los propios organizadores, aun así, en algunas ocasiones se perciben aportes de instituciones que no piden espacio político dentro de la manifestación.

\section{¿Por qué se realiza Eı Carnavalito por la vida y el amor?}

El Carnavalito por la vida y el amor, nace en el año 2007 con la idea de los integrantes de la Corporación Inti Tekoa y un grupo de madres comunitarias de la zona, quienes, a raíz de diferentes episodios de asesinatos selectivos en los barrios de la localidad de Ciudad Bolívar, (más puntualmente los barrios: Caracolí, Jerusalén, Sierra Morena, Santo Domingo, 
Santa Viviana, Los Robles y Arborizadora Alta), y sumánd ose al deseo de empoderarse del espacio territorial en el que habitan, quieren expresar su inconformidad hacia estas prácticas de amedrentamiento para la población. La iniciativa es un instrumento bastante complejo pues la organización de tal manifestación depende de la difusión y la confianza de diferentes sectores que presentan distancia y prevención pues es una negativa a la conducta de un grupo violento.

La comunidad, que quiere mostrar su voz de protesta contra la Intimidación bélica y psicológica, se idea un formato totalmente opuesto a esa violencia. La figura utilizada por los violentos y denominada como limpieza social, es una conducta coercitiva, que trabaja desde el anonimato, que es selectiva. Por el contrario, El Carnavalito busca invitar a la fraternidad como comunidad, es una manifestación popular y es incluyente.

\section{¿Cuándo se realiza el Carnavalito?}

La fecha del evento se establece para el tercer domingo del mes de septiembre, que en Colombia es el mes en que se celebra una festividad denominada Amor y Amistad. Se debe tener en cuenta que la planeación y evaluación del Carnavalito también hacen parte del mismo, siendo estas extensiones de tiempo importantes para los calendarios de reconocimiento del evento.

\section{Tabla 4}

EJEMPLO CRONOGRAMA DE ACTIVIDADES DEL CARNAVALITO

\begin{tabular}{llllll}
\hline & \multicolumn{2}{c}{ Planeación } & \multicolumn{2}{c}{ Ejecución } & \multicolumn{1}{c}{ Evaluación } \\
\hline & $\begin{array}{l}\text { Reuniones } \\
\text { programación }\end{array}$ & Sancocho & $\begin{array}{l}\text { Pre } \\
\text { Carnavalito }\end{array}$ & Carnavalito & $\begin{array}{l}\text { Reunión } \\
\text { Evaluación }\end{array}$ \\
\hline Fecha Inicio & ---- & ---- & ---- & ---- & ---- \\
\hline Fecha Final & ---- & ---- & ---- & ---- & ---- \\
\hline
\end{tabular}

\section{¿Dónde se hace el Carnavalito?}

El Carnavalito se realiza en la localidad número 19 de Bogotá, Ciudad Bolívar.

\section{Figura 7}

MAPA DE BOGOTÁ, UBICACIÓN DE CIUDAD BOLÍVAR. 


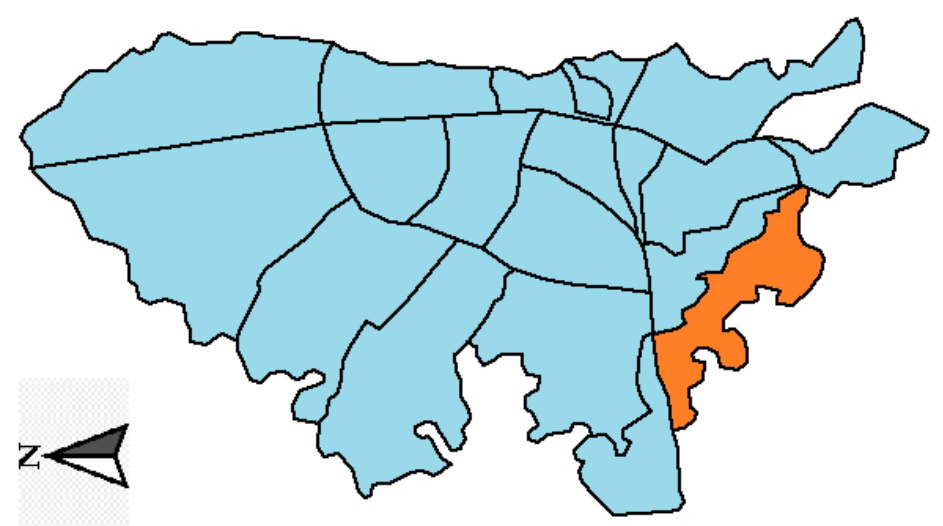

Fuente (Comisión filmica de Bogotá).

\section{Mapa Ciudad Bolívar/Trazados recorridos comparsas.}

\section{Figura 8}

MAPA TOMADO DE PLAN LOGÍSTICO $10^{\circ}$ CARNAVALITO

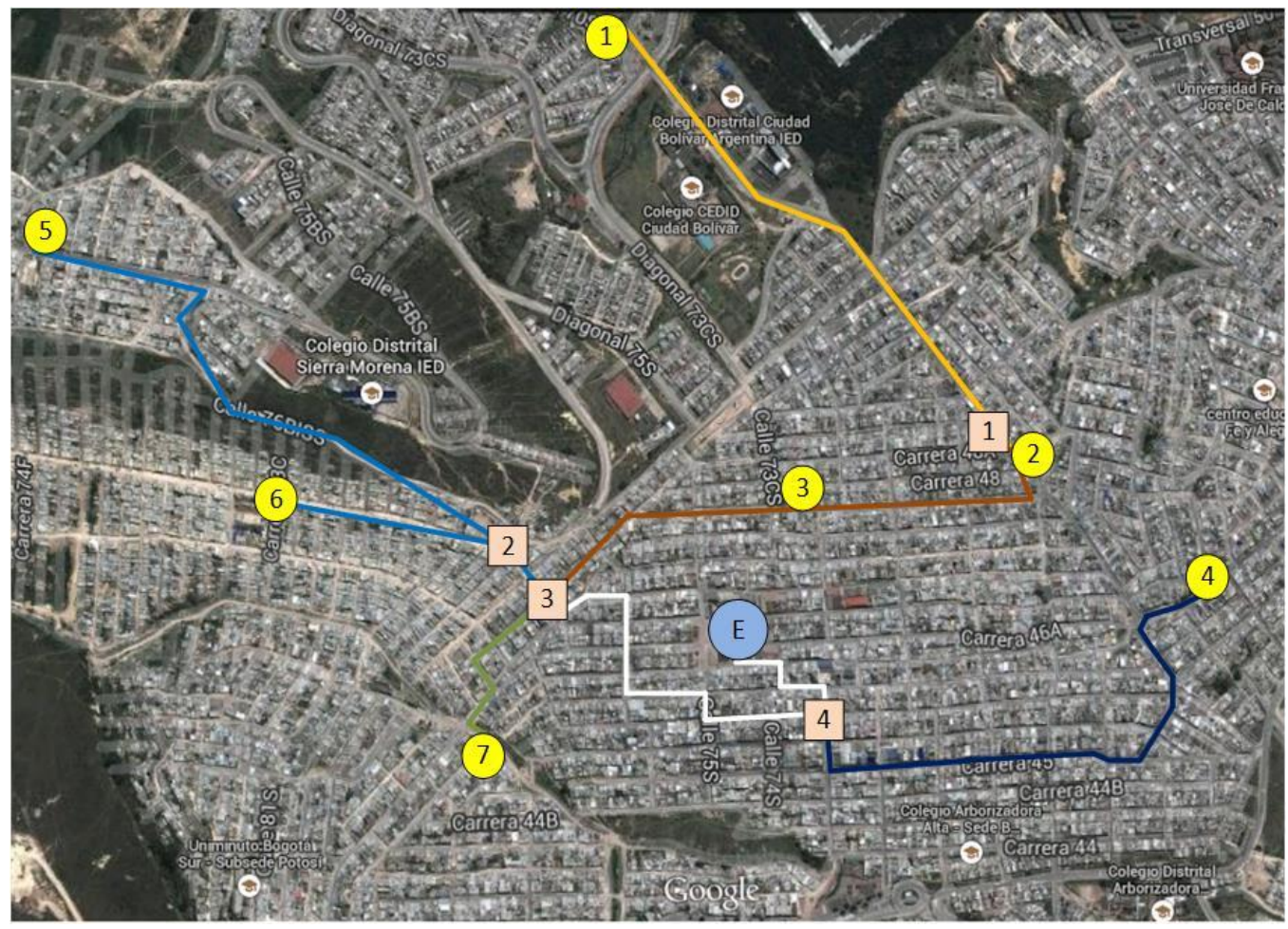

(Inti Tekoa, 2018)

\section{Esquema del mapa del recorrido}

- 1,2 , Punto De Partida Sierra Morena

Salida y recorrido de Asociación Nuevos Horizontes. Tv 60 con Dg 70 Sur y Cll 70 Sur con Cra 48A

- 3, Punto De Partida Santa Rosita: 
Salida y recorrido de la Asociación el Ensueño. Carrera 47 b \# 73 c Sur y carrera 47 b \# 70 Sur

- 4, Punto De Partida La Ye:

Salida y recorrido Asociación Paraíso, Carrera 45C con Calle 70 sur

- 5, 6, Punto De Partida Santa Viviana Y Caracolí:

Salida y Recorrido Asociación Futuros de Colombia, FEVIDI y Ámbito Familiar. Cll 75D Sur con Cra 75D y Calle 76A sur Y carrera 73C

- 7, Punto De Partida Potosí Alameda:

Salida y recorrido de la Asociación Caminito Alegre. Transversal 47 A y Diagonal 77 sur

- Puntos De Encuentro De Comparsas 1-4

- Punto De Llegada Parque Tanque Laguna

\section{E}

\section{¿Cómo se hace el Carnavalito?}

Una vez establecido el cronograma de trabajo y la planeación del proyecto, se construye la lista de lo que se necesita para la puesta en marcha del Carnavalito. La infraestructura, las presentaciones, los reconocimientos, el transporte, además de otros elementos que conforman la celebración.

La colaboración de la junta local y del acompañamiento de la policía nacional establece un contacto y aprobación de las autoridades locales. Sumado a esto se emiten comunicados a las empresas de trasporte público de la zona para que puedan anticipar las marchas sobre las vías de sus rutas que operan el día del evento.

\section{La infraestructura}

La tarima como punto de llegada de la marcha es vital para la continuidad de las presentaciones de los actores de la misma.

\section{Las presentaciones}

La puesta en escena del Carnavalito tiene dos escenarios, uno en la marcha y el otro en la tarima.

En la marcha el tema de los marchantes es establecido en la planeación del evento. Dentro de la marcha también están las presentaciones de las bandas de niños de carabineros y de colegios de la zona. 
En tarima se establece un itinerario con los tiempos y las presentaciones que se van a dar durante la jornada. Las presentaciones son acordadas por las distintas fundaciones gestoras del Carnavalito, en ellas estarán presentes diferentes actores pertenecientes a ellas e invitados de las mismas. Dentro de los formatos de estas están: bailes, cantos, concursos, recitaciones, discursos.

\section{Los reconocimientos}

Generalmente desde la tarima del evento se ofrecen agradecimientos y se reconocen a participantes y gestores del evento.

\section{EI transporte}

Se utiliza para movilizar a invitados y a los diferentes elementos que se necesitarán para la puesta en escena.

\section{¿De dónde se sacan los fondos?}

El evento se sostiene por las actividades de los organizadores como colectas o rifas/sorteos promocionadas y gestionadas por ellos mismos en la comunidad.

\section{Humanizando el vínculo}

Cecilia Ceraso (Ceraso, et al, 2007), nos ha ayudado a entender cuál es la adecuada aproximación a los actores de nuestros proyectos, concibiendo que para esta tarea se tiene que empezar humanizando el vínculo que hay de estos con las organizaciones y de los vínculos que podemos observar entre ellos mismos, encontrando que el fin último, como apreciación ontológica, es lo humano y lo social que de ellos se derive.

Ya que el Carnavalito es un evento fruto de varias organizaciones, entendemos que se debe contar con una comunicación, que, a modo de cascada, tiene que darse desde y hacia todos sus participantes.

Hemos entendido que, la comunicación transmite discursos, de estos se construyen realidades y de estas se pueden interiorizar identidades, que pueden definir el proceder tanto de grupos como de los sujetos mismos (Smith, 1997). Es por esto que reconocimos como crucial que se entendiera cuál es el flujo y las corrientes que corren por esos flujos comunicativos, ya que con estos nos aproximamos a esa identidad comunitaria para poder generar un empoderamiento y un cambio social. Las múltiples aristas encontradas en las posturas dentro de lo social, nos han servido para fortalecer las visiones acerca de la comunidad, aunque sabíamos que de nada nos sirven si no entran en la dinámica de 
interrelación, en los debates, en las conversaciones. De nada nos sirven si se quedan en el individuo y no se vuelven parte de las intersubjetividades. Encontrar puentes o la necesidad de ellos, es lo pertinente cuando queremos entrelazar posturas para crear redes. Y, qué más pertinente para salir a la comunidad a crear puentes que la manifestación del Carnavalito, donde se conjugan toda suerte de esfuerzos y deseos, pero no en forma efímera y etérea, no, estos vienen con las personas que materializan y personifican este evento.

Socializar los social coloca las historias de los actores dentro del horizonte a aproximar, establece un espíritu, unas voluntades, unos deseos y despeja la bruma de la mirada a la comunidad. Los diálogos en este ejercicio de aproximación, llevados a cabo con habitantes de los barrios de Ciudad Bolívar, las orientaciones y aclaraciones dadas por líderes de entidades como Inti Tekoa y lideresas de diferentes colectivos como las madres comunitarias, han ubicado los recursos acá plasmados, en una comunidad de personas reales con sueños y expectativas, para los cuales se orientan los alcances derivados de las iniciativas plasmadas en esta tesis. Junto a esas voces y guiados por Sembrando mi tierra de futuro (Ceraso, et al, 2007) dimos uso a la siguiente tabla, en la que reconocemos los actores principales del Carnavalito y la forma en la que se relacionan.

\section{Tabla 5}

PLANTILLA PREDIAGNÓSTICO

Plantilla prediagnóstico

\begin{tabular}{|c|c|c|c|c|c|}
\hline Los Actores & $\begin{array}{l}\text { Con quién se } \\
\text { comunica }\end{array}$ & Contexto & Canales & $\begin{array}{l}\text { Lenguajes } \\
\text { y códigos }\end{array}$ & Flujos \\
\hline Inti Tekoa & $\begin{array}{l}\text { Madres } \\
\text { Comunitarias }\end{array}$ & $\begin{array}{l}\text {-Localidad de } \\
\text { Ciudad Bolívar, } \\
\text { Bogotá. Barrios } \\
\text { del centro-sur de } \\
\text { la localidad. }\end{array}$ & $\begin{array}{l}\text {-Reuniones } \\
\text { programadas } \\
\text {-Grupo en } \\
\text { aplicaciones } \\
\text { digitales }\end{array}$ & $\begin{array}{l}\text {-Oral, } \\
\text { informal, } \\
\text { coloquial. }\end{array}$ & $\begin{array}{l}\text {-Horizontal. } \\
\text { Cada reunión } \\
\text { programada }\end{array}$ \\
\hline Inti Tekoa & $\begin{array}{l}\text { Comunidad } \\
\text { del territorio }\end{array}$ & $\begin{array}{l}\text {-Localidad de } \\
\text { Ciudad Bolívar, } \\
\text { Bogotá. Barrios } \\
\text { del centro-sur de } \\
\text { la localidad. }\end{array}$ & $\begin{array}{l}\text {-Reuniones } \\
\text { programadas }\end{array}$ & $\begin{array}{l}\text {-Oral, } \\
\text { informal, } \\
\text { coloquial. }\end{array}$ & $\begin{array}{l}\text {-Horizontal. } \\
\text { Dependiendo } \\
\text { de la } \\
\text { necesidad se } \\
\text { establece la } \\
\text { frecuencia de } \\
\text { comunicación. }\end{array}$ \\
\hline
\end{tabular}




\begin{tabular}{|c|c|c|c|c|c|}
\hline Inti Tekoa & $\begin{array}{l}\text { Entes } \\
\text { institucionales }\end{array}$ & $\begin{array}{l}\text {-Localidad de } \\
\text { Ciudad Bolívar, } \\
\text { Bogotá. Barrios } \\
\text { del centro-sur de } \\
\text { la localidad. }\end{array}$ & $\begin{array}{l}\text {-Reuniones } \\
\text { programadas }\end{array}$ & $\begin{array}{l}\text {-Escrito. } \\
\text { Formal. }\end{array}$ & $\begin{array}{l}\text {-Vertical. } \\
\text { Dependiendo } \\
\text { de la } \\
\text { necesidad se } \\
\text { establece la } \\
\text { frecuencia de } \\
\text { comunicación. }\end{array}$ \\
\hline $\begin{array}{l}\text { Líderes } \\
\text { Madres } \\
\text { comunitarias }\end{array}$ & Inti Tekoa & $\begin{array}{l}\text {-Localidad de } \\
\text { Ciudad Bolívar, } \\
\text { Bogotá. Barrios } \\
\text { del centro-sur de } \\
\text { la localidad. }\end{array}$ & $\begin{array}{l}\text {-Reuniones } \\
\text { programadas } \\
\text {-Grupo en } \\
\text { aplicaciones } \\
\text { virtuales }\end{array}$ & $\begin{array}{l}\text {-Oral, } \\
\text { informal, } \\
\text { coloquial. }\end{array}$ & $\begin{array}{l}\text {-Horizontal. } \\
\text { Cada reunión } \\
\text { programada }\end{array}$ \\
\hline $\begin{array}{l}\text { Líderes } \\
\text { Madres } \\
\text { comunitarias }\end{array}$ & $\begin{array}{l}\text { Madres } \\
\text { comunitarias }\end{array}$ & $\begin{array}{l}\text {-Localidad de } \\
\text { Ciudad Bolívar, } \\
\text { Bogotá. Barrios } \\
\text { del centro-sur de } \\
\text { la localidad. }\end{array}$ & $\begin{array}{l}\text {-Comunicación } \\
\text { en sus lugares } \\
\text { de trabajo }\end{array}$ & $\begin{array}{l}\text {-Oral, } \\
\text { informal, } \\
\text { coloquial. }\end{array}$ & $\begin{array}{l}\text {-Horizontal. } \\
\text { Cotidiana. }\end{array}$ \\
\hline $\begin{array}{l}\text { Líderes } \\
\text { Madres } \\
\text { comunitarias }\end{array}$ & $\begin{array}{l}\text { Niños de los } \\
\text { jardines }\end{array}$ & $\begin{array}{l}\text {-Localidad de } \\
\text { Ciudad Bolívar, } \\
\text { Bogotá. Barrios } \\
\text { del centro-sur de } \\
\text { la localidad. }\end{array}$ & $\begin{array}{l}\text {-Comunicación } \\
\text { en sus jardines } \\
\text { de niños }\end{array}$ & $\begin{array}{l}\text {-Oral, } \\
\text { informal, } \\
\text { coloquial. }\end{array}$ & $\begin{array}{l}\text {-Horizontal. } \\
\text { Cotidiana. }\end{array}$ \\
\hline $\begin{array}{l}\text { Líderes } \\
\text { Madres } \\
\text { comunitarias }\end{array}$ & $\begin{array}{l}\text { Padres y } \\
\text { familiares de } \\
\text { los niños de } \\
\text { los jardines }\end{array}$ & $\begin{array}{l}\text {-Localidad de } \\
\text { Ciudad Bolívar, } \\
\text { Bogotá. Barrios } \\
\text { del centro-sur de } \\
\text { la localidad. }\end{array}$ & $\begin{array}{l}\text {-Comunicación } \\
\text { en sus jardines } \\
\text { de niños } \\
\text {-Grupo en } \\
\text { aplicaciones } \\
\text { digitales }\end{array}$ & $\begin{array}{l}\text {-Oral, } \\
\text { informal, } \\
\text { coloquial. }\end{array}$ & $\begin{array}{l}\text {-Horizontal. } \\
\text { Cotidiana. }\end{array}$ \\
\hline
\end{tabular}

\section{Lo bueno, lo malo y nuestras propuestas}

Cuando buscamos tener una aproximación fiel a la comunidad y sus realidades, lo esperado es que se debe ver todo lo que más podamos de esta. Por tanto, reconocer los aspectos positivos y negativos ayuda a establecer un espectro que establece un margen en donde nos podemos ubicar. Este margen nos permite reconocer con que herramientas contamos y cuáles son los obstáculos a superar.

Para esta tarea es muy oportuno el uso de las tablas de matrices de realidades positivas y negativas que nos ayudan a observar cuales pueden ser las conexiones de esas realidades que se describen y que pueden ser cruciales si esperamos adelantar nuestras propuestas de proyectos comunitarios. Así es que la organización de las voces de los actores, de las dinámicas de la comunidad alreded or del Carnavalito, empiezan a reconocer cuáles son esas realidades en las que se encuentran inmersas y de éstas cuáles entran a aportar y cuáles restan a sus expectativas. De estas tablas se reconocen las voces y los datos planteados a 
continuación (Consultar las tablas completas de realidades positivas y negativas en el documento anexo de esta tesis).

\section{Referencias a las tablas de realidades positivas}

Lo primero y más resaltable que se hace evidente en el producto de la aplicación de las tablas de realidades positivas en nuestra comunidad, es la entrega y buena disposición a la transformación positiva de los actores presentes en iniciativas como la del Carnavalito. Esta se enmarca en principios personales que a modo de motivador ejerce como fuerza fundamental para la acción movilizadora de lideresas, líderes y demás gestores de procesos comunitarios. La iniciativa nacida de sus agencias singulares, se materializa en el desarrollo de programas que apuntan a potencializar competencias comunitarias enriquecidas por la experiencia en el campo y en la actualidad por la formación profesional de miembros de la comunidad que apoyan estos procesos. La experiencia y tradición de los líderes con más años de actividad, se fortalecen con la profesionalización de ellos mismos y los nuevos miembros participantes, trayendo nuevos saberes al diálogo en las colectividades, poniendo en cuestión los sentidos presentes en los discursos cotidianos y deconstruyéndolos.

La herencia de lo trabajado y el fortalecimiento de muchos procesos, ha traído consigo el contacto con entidades que han aportado al sostenimiento de estas iniciativas y han favorecido el llegar a exponer el trabajo realizado fuera del territorio. ONGs y universidades han sido las entidades que desde afuera del territorio han estado más activas en las sinergias con la comunidad.

La confianza forjada por la perseverancia de los gestores en sus iniciativas, ha generado buena disposición de los miembros de la comunidad para los programas tradicionales y para los que lleguen nuevos a dar su aporte, dando así más posibilidades de desarrollo no solo en la consecución de escenarios físicos sino también simbólicos.

En este ejercicio se registraron las siguientes temáticas en las tablas de realidades positivas:

Disposición para el cambio positivo de su entorno: Se evidencia una ruptura de las resistencias de la población al cambio, ya que se ha llevado un proceso que ha generado confianza para la población. Esto gracias a organizaciones de base que han visibilizado su aporte y crecimiento para la comunidad, mostrándoles acciones de cambio y participación en el mismo. 
Lideresas del territorio que han llevado sus labores más allá del estricto compromiso laboral y se han empeñado en generar cambios en su comunidad: Muchas de las acciones llevadas a cabo en el territorio, son iniciativas gestadas por mujeres que desde sus saberes materializan proyectos, que buscan suplir necesidades encontradas en el territorio. El empoderamiento y el cambio de discursos son evidencias de estas transformaciones encarnadas en las lideresas que en otrora fueron parte de un territorio vacío de aportes y del cuál ahora ella son constructoras.

Jóvenes profesionales que trabajan en y por su comunidad: al encontrar un crecimiento demográfico tan significativo en la localidad de Ciudad Bolívar, encontramos también un mayor número de historias de habitantes del sector que se han profesionalizado y que en su ejercicio de participación ciudadana se han unido a iniciativas de trabajo social, aportando con sus saberes a la transformación del territorio.

Integrantes de la comunidad dispuestos a participar positivamente en la construcción de una identidad de la comunidad: La propia disposición del Carnavalito como espacio abierto a la inclusión y como fiesta popular que se toma el espacio público, es una invitación a la integración y la construcción de sentidos de la comunidad en general. El crecimiento demográfico y el gran trasado del recorrido por el territorio hacen que el impacto de la caravana llegue a más habitantes de la comunidad, generando mayor difusión de estas iniciativas y extendiendo puentes a la participación de los habitantes del territorio a que sumen sus aportes a la realización de la fiesta popular.

Contacto de las organizaciones del sector con entidades fuera del territorio que contribuyen a mostrar el trabajo de la comunidad: La confianza dada por los años de trabajo en el territorio ha generado que se extiendan puentes a entidades como $\mathrm{ONG}^{\prime}$ 's e instituciones académicas que aportan desde sus competencias a la transformación de la comunidad. Espacios de pasantías profesionales, desarrollo de programas, recepción de formación para integrantes de la comunidad por parte de profesionales, práctica de idiomas por instructores nacionales y extranjeros, han sido parte de esas integraciones presentes en el territorio.

Experiencias positivas establecidas como base por entidades del territorio que llevan décadas desarrollándolas: parte del incentivo que reciben los gestores de las iniciativas transformadoras del territorio son los éxitos de sus intervenciones. El reconocimiento de habitantes del sector y la extensión en el tiempo dan cuenta de las herramientas construidas para el desarrollo territorial y la fundamentación de identidades positivas de la comunidad.

Nuevos escenarios para el fomento de la construcción positiva de la comunidad: aunque se sabe que no son los suficientes, si se reconoce que se han generado espacios nuevos 
producto de esfuerzos mancomunados, que han tenido como meta la mejora de las condiciones de vida de los habitantes de la comunidad y que han dado lugar al fomento de acciones de transformación.

Nuevos canales comunicacionales que pueden ejercer una nueva forma de contacto con la comunidad: el derecho humano a la libre expresión abarca la necesidad de tener voz propia y de que esta voz se escuche en la comunidad misma. Una autorreferencia que genere sentidos propios es favorecida con una interacción como la prestada por los espacios digitales y los nuevos dispositivos de comunicación. La hiperconectividad de nuestros tiempos y el acceso que se da al uso de estas tecnologías para la mayoría de habitantes de la comunidad, abre la posibilidad de establecer diálogos entre las entidades territoriales y la comunidad en general.

\section{Referencias a las tablas de realidades negativas}

Parte del ejercicio de aproximación al territorio, también es reconocer los aspectos a mejorar. Siendo esto clave para poder problematizarlos y tomarlos como punto de partida para la transformación positiva. La dificultad para establecer conexiones fuertes y consistentes entre las organizaciones de base del territorio y entre estas y la comunidad en general son aspectos que se vuelven uno de los retos abordados por las instituciones que trabajan en la gestión del Carnavalito.

La indiferencia de un gran número de habitantes de los barrios de las UPZ 69 y 70, hacia iniciativas de las instituciones de trabajo social, han generado que gran parte de las fuerzas de estos procesos se pierdan, en ocasiones impulsado esto por la coerción de grupos violentos que trabajan desde las sombras y que coartan el ejercicio participativo. Sumado a todo esto, la ausencia de un Estado que supla las necesidades básicas para el desarrollo de los grupos sociales, hace que la comunidad alrededor del Carnavalito sea un escenario con falencias, pero con un espacio que busca intervenciones para la transformación positiva.

En este ejercicio se registraron las siguientes temáticas en las tablas de realidades negativas:

Indiferencia de la comunidad ante proyectos que los benefician: la falta de una formación participativa a los habitantes del territorio, genera una pasividad que imposibilita la transformación, ya que genera unos sujetos llevados a su ensimismamiento, a la entropía y el silencio; muchas veces sosteniéndose estas actitudes en estructuras simbólicas como lo son los sentidos que circulan en los discursos colectivos. El reconocer que las fuerzas generadas por el Carnavalito llegan con potencia a los actores que son parte de su gestión también nos 
obliga a reconocer que esa potencia no llega con la misma intensidad a los habitantes que están fuera de la organización del evento.

Fuerzas oscuras que ejercen con violencia sus imposiciones en la comunidad: El abandono del estado en estos territorios ha generado que grupos al margen de la ley puedan ejercer violencia con toda comodidad. Aunque se puedan crear políticas que busquen mitigar esas situaciones la realidad es que estas no llegan a eliminar estos grupos ni a reducir su impacto negativo. Una constante es que, ante el silencio de la población y de las autoridades, estos grupos violentos ganen terreno y tomen impulso para perpetrar sus actos.

Dificultades comunicacionales entre las entidades y entre las entidades y la comunidad: las dimensiones de la población de la localidad de Ciudad Bolívar, exigen un esfuerzo enorme para abordar a su totalidad, por tanto, es un reto llegar a ese volumen de habitantes, pero en este apartado no se resalta la dificultad de la aproximación a ese gran número sino la resistencia y la desidia de los habitantes del territorio que estén fuera de la organización del Carnavalito para apoyarlo a este como una fiesta popular. La dificultad para ampliar el empalme de las agendas de trabajo entre las diferentes organizaciones de base del territorio, también ha dificultado que se tomen un gran número de eventos en conjunto para potencializarlos.

Dificultades de formación en herramientas que contribuyan a establecer puentes con la comunidad: la ausencia de un programa consistente que enseñe al uso de tecnologías dispuestas para la comunicación, dificulta la realización de contenidos desde, con y para la comunidad. La voz propia de un territorio, aunque es la fuente de todas las iniciativas comunitarias, encuentra limitaciones si no se difunde para que aborde discursos de comunidades que puedan tener ideas erróneas del territorio que está difundiendo su voz propia.

Escaso apoyo estatal a propuestas de construcción de comunidad: la ausencia del Estado en frentes de necesidades básicas del desarrollo de la comunidad, hace ver el espectro de las falencias que se pueden hacer presentes en el territorio donde se celebra el Carnavalito. El débil o ausente apoyo a intervenciones territoriales es una generalidad del presupuesto colombiano y no es la excepción la localidad de Ciudad Bolívar al sur de Bogotá. Además del frágil apoyo económico, la falta de cobertura e inclusión en programas Estatales que den difusión y formación a iniciativas como la del Carnavalito por la vida y el amor, ubican a esta fiesta popular como un evento gestad o por la iniciativa propia de los habitantes de la zona. Tomamos esto último como algo positivo, lo que no es positivo es la evidencia de un estado débil o ausente para la promoción de acciones de crecimiento comunitario. 


\section{Las palabras de los actores}

Las acciones primera y última de todos los procesos sociales las realizan los miembros de las entidades a las que nos aproximamos, aquellos que abren sus puertas, aquellos que acomodan sus agendas y la mejor de sus disposiciones para que se puedan adelantar propuestas que contribuyan a su comunidad, y es, por tanto, crucial que sus voces sean parte de todo ejercicio de intervención en las comunidades, pues de esta manera se establecen los puentes entre las voces de aquellos que queremos escuchar y los pasos que queremos recorrer.

Para el recorrido que se ha realizado en nuestro territorio, se han llevado a cabo varias entrevistas que, junto al hecho de compartir escenarios de la cotidianidad de la comunidad, han guiado la totalidad de lo plasmado en esta tesis.

El líder Fernando Cardona y las lideresas Flor Alba Herrera y Miriam Martínez han sido de esos miembros destacados de las comunidades que uno agradece encontrarse en la vida, ya que son un ejemplo de voluntad y compromiso.

Estas entrevistas han sido seleccionadas ya que en ellas se reconocen las identidades y deseos que se encuentran en las comunidades cuando uno se sumerge en ellas. Expresan sus experiencias, realidades y proyecciones en relación a su territorio y a sus proyectos en, para y por la comunidad. A continuación, traemos unos apartes de las respuestas de estas entrevistas $^{23}$.

\section{Parece que eso no fuera significativo, pero un cambio en el lenguaje permite un cambio en la forma de pensar}

Entrevista a Fernando Cardona

Por Juan Carlos Nieto

Fernando Card ona, es un líder comunitario natural. Cuenta con la convicción de hacer comunidad mediante la construcción de escenarios no tradicionales de educación y de participación. Años de actividad territorial han fortalecido su visión y profesionalismo, acerca de la importancia de la edificación social desde la educación popular. Función que ha ejercido dentro y fuera de Colombia. Director de la fundación INTI TEKOA, además de profesor Universitario, Fernando es un ejemplo para su comunidad.

Fernando Cardona:

\footnotetext{
${ }^{23}$ Las entrevistas completas se encuentran en los anexos en el apartado de apéndice.
} 
Digamos que una de las cosas que ocurren en estos territorios, es que hay un imaginario de la gente de afuera frente a las personas que habitamos Ciudad Bolívar, y es que somos personas incapaces, personas problemáticas, personas que poco podemos aportar a la transformación de la sociedad y ese imaginario se reproduce dentro de la misma comunidad. Entonces la misma comunidad, a veces, se considera incapaz de poder ser autor y tener incidencia en su realidad. El propósito de Inti Tekoa es demostrarles que eso no es así y que efectivamente se tienen todas las capacidades y habilidades para poder ser protagonista de su propia realidad y cambiarla, y no sólo esperar que vengan agentes externos a pensar que solamente con la ayuda de ellos se puede cambiar eso. Si bien no desconocemos la capacidad, los aportes que hace un agente externo, consideramos que como comunidad se tienen los elementos suficientes, solamente que esos imaginarios a veces son tan fuertes que generan, crean como un velo, que no permite ver un poco más allá, y la apuesta de Inti Tekoa es mostrar que sí es posible, y pues partimos de nuestro ejemplo, todos somos nacidos en Ciudad Bolívar, algunos bueno, algunos nacidos en Ciudad Bolívar, como yo, otros que han migrado de los campos hacia estos sectores, pero todos con la idea de mostrar que si somos capaces, que estando en Ciudad Bolívar si tenemos los elementos suficientes para poder transformar, y pues la muestra es eso, algunos de nosotros ya estamos terminando los posgrados en el tema académico y otros están ya empezando a generar este proceso.

El lugar en el que está ubicada Inti Tekoa es un sector deprimido de Ciudad Bolívar, un sector receptor de una población bastante alta de desplazados, con un nivel de pobreza alto, con situaciones de violencia bastante altos, con presencia de grupos armados también muy alto. Es una población que sufre los embates del sistema económico.

El Carnavalito es el resultado de dos situaciones que se encontraron en algún momento. En 2005-2006 en Ciudad Bolívar ocurre una oleada de muertes sistemáticas de jóvenes dentro del marco de lo de la llamada limpieza social, y, Inti Tekoa, empieza como a participar en acciones de reivindicación de la vida y de resistencia, frente a esas situaciones violentas. En una de esas, participamos en lo que se llamó La Marcha Por La Vida. Fue un ejercicio que se hizo en Ciudad Bolívar, en el que se marchó hasta el parque el Tunal, allí se acampó y era una forma como decir "mire, pues no estamos de acuerdo con las muertes de los jóvenes, independientes cuáles eran las razones y cuál es la justificación es para hacerlo. Pero, no estamos de acuerdo con esa forma en que a nuestros jóvenes los están asesinando constantemente". Porque aquí era muy normal que a los jóvenes los mataran a las 2 de la tarde, a las 6 de la mañana, a las 10 de la noche, a las 5, a las 8 , y delante de los niños, delante de todo el mundo. La muerte aquí, el desprecio por la vida era bastante alto. Entonces, esa 
propuesta, se encuentra con una [propuesta] de las madres comunitarias, que el Instituto de bienestar familiar les solicitaba a que ellas hicieran un proceso de inserción comunitaria. Esas dos ideas se encuentran. Uno de los integrantes de la organización es hijo de una de las madres comunitarias y trae la propuesta a Inti Tekoa, de por qué no ayudarles a hacer algo a las mujeres. Entramos en diálogo con ellas y en un principio se pensó que la actividad fuera un ejercicio, una acción puntual, entonces ellas pensaban hacer una salida el día el 31 de octubre del 2007 y con los niños, salir con los niños disfrazados. Nosotros en discusiones ya más colectivas, empezamos a pensar que no fuera un ejercicio mediático, Entonces, como estábamos en el tema de toda la violencia que se estaba dando en el territorio, pues, propusimos que hiciéramos una acción que llamara la atención frente a eso, ósea, un poco visibilizar el trabajo de las mujeres y a la vez, pues, mostrarles nuestra manifestación de indignación frente a la muerte de los jóvenes.

Digamos que la apuesta fundamental de nosotros es que el Carnavalito se convierta en una forma alternativa de trabajo colectivo. Que a través de la fiesta la gente pueda manifestar sus intereses, pero también sus indignaciones frente a situaciones complejas. Que se puede visibilizar una cara más positiva del sector. Ciudad Bolívar es considerado una de las zonas rojas de Bogotá, por muchas situaciones, los medios de comunicación sólo se centran en mostrar ese lado negativo y eso hace que se construya un imaginario muy fuerte de las personas que no conocen Ciudad Bolívar y pues de las mismas personas que la habitan a veces como que creen que eso es real y lo siguen afianzando.

Entonces es un poco la apuesta de Inti Tekoa en este momento, o desde siempre, era "no, este es un trabajo colectivo, esto no es de Inti Tekoa sino es un trabajo que hacemos en conjunto". Hoy las mujeres ya lo anuncian, efectivamente, de esa manera, y parece que eso no fuera significativo, pero un cambio en el lenguaje permite un cambio en la forma de pensar y consideramos que hemos logrado un avance bastante significativo en eso.

Iba a decir una cosa y es que nuestra apuesta política, porque una de las cosas que ha ocurrido y que ocurren en estos, nuestros países latinoamericanos, es que hay una concepción de la política como esta práctica malintencionada de mirar cómo yo engaño, cómo entro para mirar cómo usurpo el dinero de las mayorías y demás. Digamos que nosotros, la apuesta política es precisamente cambiar esa visión de lo político y mostrarle a la comunidad que político es tanto la acción que hacen ellos al interior de los jardines pensando en cómo enseñarle a los niños o motivar a los niños esa idea de reconocerse y aprender a respetar al otro, como una acción política es lograr movilizar a un número considerable de personas para mostrar que Ciudad Bolívar tiene una cara distinta, que está conformada por seres humanos 
maravillosos y que pueden ser actores incidentes dentro de su realidad y además porque lo hacen, porque son muchos de los que habitamos Ciudad Bolívar somos los que dinamizamos parte de la ciudad. Entonces la apuesta política plantea precisamente es que aquí hay que trabajar con sujetos críticos.

Entonces la apuesta política es ayudar en la conformación de sujetos críticos y propositivos frente a su realidad y cómo desde esa posición crítica se plantean nuevas formas de construcción de lo comunitario y consideramos que es clave que en esa medida en que logremos eso es posible que podamos tener nuevas generaciones que sigan revirtiendo a la comunidad.

\section{Porque ese es el lema de nosotros}

Entrevista a Flor Alba Herrera

Por Juan Carlos Nieto

Una lideresa comunitaria que a través de los años ha logrado ser parte del cambio positivo dentro de su territorio. En la dirección de sus espacios para la formación de los niños de su comunidad ha tenido ya varias generaciones de los integrantes del territorio que han contado con espacios de acogimiento y cuidado, acordes con una visión de mejor calidad de vida para los ciudadanos de Ciudad Bolívar.

Flor Alba Herrera:

En mi comunidad hay gente difícil, pero también hay gente muy buena. Por ejemplo, es gente que ha venido con nosotros trabajando desde hace muchos años, entonces, por ejemplo, están los de la junta de acción comunal, está, por ejemplo, acá había mucho comité, está CELODIJE, que es parte de nosotros, porque nosotros lo ayudamos a construir. O sea que pues, a mí me conocen mucho porque yo llevo muchos años con la comunidad y a través de mí pues, entonces, conocen a mí otra gente, mis compañeras. Entonces es muy importante y tenemos muy buena relación con los vecinos, con la misma comunidad, con la junta, con todos nosotros. Y nosotros aquí al que llegue, nosotros le abrimos el corazón, porque ese es el lema de nosotros, que es trabajar para poder atraer a nuestra comunidad.

Porque todo el mundo dice que es que Ciudad Bolívar es no sé qué, ¡no!, nosotros tenemos que mostrar, aquí hay muchas cosas buenas y muchas organizaciones buenas.

Pues, lo ven... pues... como usted sabe los medios de comunicación siempre sacan lo más malo de Ciudad Bolívar. Pero es mentira, porque nosotros aquí hay mucha gente buena y echada para adelante. Y muchas organizaciones que a usted aquí llega y usted no lo van a 
recibir, como dicen... uno coge un taxi y le dicen 'uy, no, Ciudad Bolívar', no, yo si les digo 'camine y les muestro mi barrio, que no es como usted lo pintan'.

Entonces, yo sí me siento orgullosa de vivir en Ciudad Bolívar.

\section{Me voy porque yo tengo un compromiso con la comunidad}

Entrevista a Miriam Martínez

Por Juan Carlos Nieto

Madres Comunitarias

Una lideresa y gestora comunitaria. Con una experiencia de primera mano en la evolución de su territorio. Madre Comunitaria que inició su tarea mucho antes que el Estado se hiciera cargo de estas actividades con los niños de su comunidad. Una de las fundadoras del Carnavalito y de las que aún gestiona después de más de una década en esta tarea.

\section{Miriam Martínez:}

Pues, el mayor aporte que se hace, en ese sentido, es que al ir papá y mamá a trabajar, o muchas veces acá se ven muchas familias que solamente son madres solteras o padres solteros, si me hago entender, o los abuelos, en ese sentido al tener los niños en el jardín mientras que ellos trabajan pues se les mejora la calidad de vida. Porque, ejemplo, si ellos antes no tenían para un agua de panela, ya con trabajo, pues, ya van a comprar una bolsita de leche, un pedacito de carne, van a comprar zapaticos, el vestidito, se les va a mejorar la calidad de vida. Porque, en ese sentido, hay papás que andan, un ejemplo, trabajan de ambulantes, ellos no pueden ir con sus hijos, y menos ahora que la ley, siempre la ley está contra ellos, pero entonces ellos se amarran para poder coger ingresos. Y entonces esto si sirve, porque mientras que ellos están acá [los niños] y [los padres] se están buscando para mejorar su calidad de vida.

La comunidad, pues, en una época, hace muchos años, pues hace harto, pues, siempre hubo un ambiente pues como pesado, como de violencia, donde no se respetaba el derecho ni a los niños, ni a los adultos, ni a las mujeres. Y pues siempre era un ambiente como muy, muy fuerte, no, para los niños.

Por el mismo motivo, que no habían como ocupaciones para ellos. De ahí depende, ósea, de ahí de pronto salió el esfuercito de crear o de hacer el Carnavalito. Porque por parte, un ejemplo, de nosotros como institución de madres comunitarias, nosotros veíamos la necesidad de que la comunidad nos viera, que nos... no nos viera como las mamás que limpian a sus hijos, les hacen aseo, le dan de comer, los acuestan a dormir, sino que nosotros como madres comunitarias podemos hacer cosas más grandes. 
Y en la parte, por decir, hablando de la otra parte, los niños mantenían mucho en la calle, los niños no tenían quien los cuidara, amanecían muertos, no se sabía por qué. Entonces, por parte de las madres comunitarias, vimos la necesidad de sacar y mostrar nuestro trabajo, con otra compañera de otra asociación, creamos como salir a una fiesta de disfraces, salir y hacer una marcha de disfraces. La compañera tenía un integrante de la familia, un hijo, y él trabajaba con lo de estudiar, con muchachos de INTI TEKOA, donde se formó INTI TEKOA. De ellos, pues, nos dijeron que qué queríamos hacer y nos brindaron ayuda. Nos brindaron ayuda para poder desarrollar nuestra idea, se puede decir. Entonces ellos nos escucharon, le colocamos el nombre y todo eso y salimos. Pero ya nosotros vimos que la gente como que si nos prestó atención y entonces eso comenzamos como a la publicidad que eso es demostrando que hay cosas distintas a estar en la calle, estar en la violencia, golpear los niños, maltratarlos, que podemos como comunidad hacer cosas distintas y que unidos lo podíamos hacer.

Ósea, yo algún día de aquí a 2 años, 3 años, yo salgo como madre comunitaria, por "X", "Y" motivo, pues me toca irme del barrio, y le cuento que yo digo que dejé algo como, como escrito, como algo, como para recordar, o fui parte de ese algo, no es que yo lo haya dejado, pero dejé algo, un granito de arena, como para que la comunidad se dé cuenta que uno puede hacer cosas si uno se une, si uno se pone metas.

Ósea para mí, yo a pesar así, por lo menos en este carnaval, pues yo estuve muy enferma, y yo estaba pensand o, yo no podía ir. Yo estaba pero enferma, pero me tocó medicarme, pastas, médico, lo que sea. Y yo fui, porque ya era un compromiso, ósea para mí es un compromiso. 'Que el domingo que hubo un paseo a Melgar'24, no hay Melgar, me voy porque yo tengo un compromiso con la comunidad'. Entonces uno deja como una semillita de unión, de trabajo en comunidad y de amor por los niños.

\section{Diagnosticando la realidad comunitaria}

En la búsqueda de identificar las expectativas de la comunidad alrededor del Carnavalito, las voces de los actores del territorio han determinado las lecturas que de este se han dado. Han favorecido las aproximaciones que nos han permitido ser parte de esta realidad y aportar positivamente a esta.

En esta experiencia de vida hemos podido encontrar momentos, lugares y personas que enseñan en lenguajes que no se encuentran en libros ni academias. De estas experiencias

\footnotetext{
${ }^{24}$ Balneario a donde se viaja para vacacionar cerca de Bogotá
} 
formadoras, el enriquecimiento personal y profesional es parte de esas recompensas que acrecientan no solo la visión del mundo sino la posición propia en este. Sin necesidad de generar controversias entre las aulas y los territorios, hemos tomado la riqueza de estos aportes, pues todo suma.

Hemos podido encontrar contenidos propios de la comunidad y sus proyecciones acerca del Carnavalito. Elementos que nos han ayudado en la construcción de líneas de acción que se proyecten como instrumentos que potencien a la comunidad.

Para aclarar lo encontrado en esta aproximación hemos de describir el proceso llevado a cabo con la comunidad y de esta forma entenderlo en sus etapas.

\section{Selección del diseño}

Entendiendo, que ha sido nuestro deseo conocer a la comunidad de los barrios de la parte sur de las UPZ 69 y 70, Ismael Perdomo y Jerusalén, de la localidad de Ciudad Bolívar, de la ciudad de Bogotá, Colombia, que ha estado alred edor del Carnavalito, podemos entender que esta comunidad cuenta con unas condiciones de vida particulares, ya que son una población de estratos bajos, con una muy alta migración de desplazados por el conflicto armado en nuestro país. Además de eso, basta con consultar los informes de los gobiernos locales para entender que el territorio en donde se lleva a cabo el Carnavalito, presenta unos altos índices de violencia, de carencia económica y de estigmatización por parte de la población de Bogotá.

Concibiendo estas realidades, nos hemos aproximado a varios de los integrantes del sector, que han establecido escenarios de resistencia frente a esas contrariedades que se les han presentado en el que hacer de su comunidad y en el trasegar de sus propias vidas. Quienes nos han ayudado a entender cuáles pueden ser los procesos comunicacionales de la comunidad y que reconociéndolos a estos se puedan fomentar en búsqueda de la construcción de identidades de la comunidad y de una construcción de memoria colectiva.

Para llevar a cabo esto hemos entendido que no hay mejor camino que conocer a la comunidad misma, recorrer sus calles y conocer a sus integrantes. Es por tanto que esta intervención ha abordado a los participantes de esta, incluyendo a aquellos que hemos llegado en principio como observadores y que nos hemos ido involucrando en los movimientos naturales de este juego de intersubjetividades, para terminar, aportando gratamente a esas iniciativas que procuran el mejoramiento del territorio y de sus habitantes. 


\section{Determinación de las técnicas / Instrumentos}

La observación participante, como forma de involucrar al, en principio, observador, genera una importante experiencia dentro de la comunidad, ya que se agrega a un nuevo integrante a las dinámicas y procesos que desarrollen los habitantes del territorio. El aporte que pueda brindar este nuevo partícipe a las ya establecidas propuestas de la comunidad y la riqueza de experiencias ofrecidas por la misma, generan una simbiosis que germina en una construcción de nuevas propuestas, entendiendo como fin último la mejora en la calidad de vida de los habitantes del sector.

Dentro de las actividades llevadas a cabo por instituciones del territorio, como lo es INTI TEKOA, se ha buscado que haya espacios en donde se pueda aportar a los usuarios de la comunidad y que se haga uso de los conocimientos del interventor, y que esto se haga entendiendo que se es ahora parte de la dinámica desarrollada por esta institución.

Hemos sido partícipes de espacios de dinámicas comunitarias, donde el aprendizaje ha facilitado el aprehender de saberes, generados en estos escenarios brindados por varios de los líderes que integran a la comunidad. Una historia mientras se comparte un café, una anécdota en un almuerzo, una charla mientras se caminan las calles de los barrios, han brindado esa aproximación a las realidades comunitarias, incluso en algunos momentos se ha dispuesto el orden para un diálogo más profundo o para realizar entrevistas. Algunas de ellas han podido ser grabadas en audio y otras en video. Tres de estas han sido incluidas en este documento. Estas tres fueron escogidas considerando que han sido las que recogen con mayor fidelidad la voz de las dinámicas y deseos de la comunidad. Han sido realizadas con la mejor de las disposiciones de parte de los entrevistados, quienes han entregado unos mensajes honestos y constructivos (Las versiones completas de estas entrevistas se encuentran en el apéndice de esta tesis).

Las grabaciones de audio, video y las fotografías que han sido tomados en el territorio, han sido herramientas que han alimentado las aproximaciones y que han de ser parte de los cimientos para edificar la memoria colectiva de la comunidad.

La fraternidad que se encuentra en los gestores de las iniciativas comunitarias y el compromiso que se les observa, son un algo que se ve en las conversaciones que se encuentran en su cotidianidad. La actitud y las formas en que estos líderes ven su realidad enseñan a tener a la persistencia como una de las bases en las que uno debe construirse. 


\section{Acceso al ámbito de investigación}

Uno de los detalles en los que se puede pensar que se llegue a exceder a los alcances iniciales de esta tesis es, posiblemente, algún escenario que uno creería que no tiene repercusión en esta, pero, en este caso, el que me llevó a conocer a Fernando Card ona, líder de su comunidad y uno de los fundadores de la Corporación Inti Tekoa, ocurrió a muchos kilómetros del territorio que ahora abordamos. La frontera entre Bolivia y Argentina, del año 2012, fue el lugar en donde me cruzaría el camino con el ahora director de la Corporación INTI TEKOA, quien me ayudaría a conocer El Carnavalito y la comunidad alrededor de él. El tránsito desde la frontera hasta La Ciudad Autónoma de Buenos Aires, dejaría en el aire el hecho de una posible colaboración profesional. Colaboración que empezaría más de tres años después, cuando nos reunimos nuevamente en Bogotá.

Una historia de vida y las experiencias acumuladas por este líder en el territorio, fueron parte de la introducción al escenario del que ahora hace una descripción este documento.

\section{Selección de informantes / Entrada en el campo}

El encuentro/selección, con miembros colaborativos, que en su comunidad son referentes de transformación, ha sido clave para lograr apropiar más adecuadamente las experiencias presentes en el territorio. Entender el significado que para ellos conlleva el territorio ayuda a aclarar el por qué muchos de sus esfuerzos y de su perseverancia se hacen presentes en sus acciones. Saber que su motivación no se limita a la acción de algún ejercicio y a los productos de estos, enseña a reinterpretar la idea de intervención, ya que para ellos intervenir es parte de sus cotidianidades y no solo una función práctica de una propuesta.

El reconocimiento de su comunidad y su experiencia personal ratifican el que sus aportes sean de enorme importancia no solo para este documento sino para el territorio mismo. Líderes y lideresas nacidos y formados en el territorio, expresan ese sentido de pertenencia esperado para la construcción de identidades comunitarias que pueden impregnar de compromiso a otros habitantes del sector y otros muchos que puedan llegar a este o también para aquellas generaciones que vengan o estén por llegar.

\section{Recogida de datos y determinación de la estancia en el escenario / Retirada del campo}

Los datos acá reunidos han sido compilados por el autor y colaboradores desde el año 2015, aunque algunos de los datos de los que hemos tenido acceso han sido parte de experiencias anteriores de la comunidad. 
Grabaciones de la caravana del Carnavalito, en jornadas que se llevan a cabo una vez por año, eventos previos a esta caravana, como lo ha sido el pre Carnavalito, los sancochos comunitarios y reuniones para la gestión del mismo, son lo que en sí se conoce como el Carnavalito y no el evento final de la caravana. Estos escenarios y los materiales en ellos recopilados, además de la participación en espacios de la cotidianidad, son lo que hoy entendemos como los datos necesarios para el reconocimiento que se ha llevado a cabo en esta iniciativa y que son compilados en este documento.

Después de varios años de aproximación a estas dinámicas de interrelación, se ha considerado que el banco de datos y las experiencias y aportes con miembros de la comunidad son suficientes para el desarrollo de un diagnóstico acerca de los contextos del territorio y con estos poder concebir líneas de acción ante los escenarios encontrados en estas realidades.

\section{Procesamiento de la información}

Después de recabar concienzudamente el material acumulado a través de los años, se han seleccionado los contenidos que mejor contribuyen a la descripción de lo que se ha querido plasmar en esta experiencia, y esto tratamos de aclararlo un poco fuera de este texto ya que una gran parte del conocimiento excede el volumen de este documento, pero plácidos podemos decir que se encuentran en el territorio.

El marco académico ha sido de vital ayuda para poder llevar de manera más eficiente la marcha que conlleva este tipo de iniciativas. Aunque puede llegar a ser en ocasiones abrumante y desearse que todo se pudiese llevar de manera más intuitiva, se ha encontrado en varios autores, acá citados, a unos buenos guías para ejercer nuestra ciudadanía profesional en campos que trascienden lo estrictamente académico. Parte del viaje comunitario es entender esa paradoja de que muchas veces los autores académicos nos enseñan a entender lo que pasa fuera de las lógicas de las aulas y que saliendo de ellas el interventor tiene que plantar bien los pies en el terreno para que este se abra y nos permita vislumbrar sus detalles.

Observaciones, charlas, meditaciones y unas cuantas memorias digitales llenas de material, han sido la materia prima de nuestro proceso. Las memorias han sido poco a poco filtradas con la ayuda de los objetivos planteados en este documento y que buscan una linealidad que nos ayude a reconocer cuáles pueden llegar a ser los contenidos que más contribuyan a estos fines.

Horas de análisis y corrección de estos han podido dar cuenta de lo acá recabado. 


\section{Elaboración del informe}

Finalmente podemos dar cuenta de lo hasta acá compilado, del camino recorrido por años de aproximación y de orientaciones venidas del territorio y sus actores, y dar un viso de lo que se ha encontrado.

\section{En los Actores}

Los líderes actores acá encontrados a través de toda la aproximación cuentan con un factor común y es el completo compromiso con su comunidad y su territorio. Desde sus herramientas propias se pueden reconocer las huellas dejadas en el territorio y su deseo de que se puedan continuar estas actividades por nuevos miembros de la comunidad.

Se reconoce un respeto mutuo entre los líderes y entre estos y la comunidad en general.

Aunque el objetivo siempre es la comunidad en general, es claro que la mayor cantidad de los esfuerzos de las instituciones del sector, están orientados hacia los niños de la comunidad, siendo estos los mayores usuarios de todas las actividad es ofertadas por las instituciones del territorio. Con lo anterior es más fácil poder concluir que los niños son el actor principal de la comunidad y esto se sustenta en la visión que tienen los líderes comunales acerca de lo que ven a futuro y es encontrarse en su territorio con ciudadanos formados con una nueva visión de su sector y que cuenten con unos procesos cognitivos y personales que inviten a contribuir positivamente a su comunidad. Por esto, podemos considerar que las comunicaciones de las instituciones del sector estén dirigidas de manera más atractiva y eficiente a esta población y hacia sus acudientes.

\section{En los sentidos}

La realidad simbólica en la que se encuentran sumergidos los habitantes del sector, donde se llevan a cabo iniciativas como la del Carnavalito, genera, en la mayoría de los casos, muros infranqueables, La aceptación de estas realidades, muchas veces impuestas, genera no sólo la aceptación de estos esquemas mentales, sino, además, la réplica y sustentación de las mismas prácticas. Familias que naturalizan la sumisión de la mujer y las mujeres que en su discurso justifican agresiones de todo tipo, son un ejemplo de las realidades que se encuentran en un alto número en la localidad de Ciudad Bolívar. En la entrevista al líder Fernando Cardona podemos entender claramente la importancia de abordar los sentidos que circulan en las representaciones comunicacionales del territorio. Esta idea se entiende con la frase "Parece que eso no fuera significativo, pero un cambio en el lenguaje permite un cambio en la forma de pensar". 
Con esto podemos entender que eventos como el Carnavalito enseñan a crear nuevos esquemas mentales y contenidos discursivos que ayudan a deconstruir las visiones y estigmas que conlleva, según los estereotipos que circulan en los discursos de ciudad, el ser habitante de este sector.

Y es, por tanto, que se debe reconocer lo bien que acá se lleva la tarea en este sentido. Se podría desear que se fomente de manera enérgica esta iniciativa y que se generen más espacios como los que ya se han construido para continuar con este proceso.

\section{En los lenguajes}

La posición que toman los líderes y lideresas de la comunidad dan cuenta de un empoderamiento por las actividades de su sector. Aunque reconocen que la tarea por hacer es aún enorme, no se repliegan y, con mayor vitalidad, transmiten eso a los depositarios de sus esfuerzos. Se hace claro en el documento que, si hay algo con lo que cuentan los líderes de la comunidad, es la constancia. Una vida de compromiso ha producido en su territorio voces que se resisten a imposiciones como la de los violentos, pero, entendiend o que es como comunidad como se es más fuerte.

La tarea continuará, aunque se esperaría que ésta fuese menos ardua si se contara con el apoyo del Estado, tanto nacional como local, para mitigar las dificultades presentes en el sector. Seria esperable que se pudiese contar con una difusión más amplia de las actividades que se llevan en el sector ya que, aunque se pueden encontrar voluntades férreas, también se pueden oír expresiones de desgaste por la ardua labor. Por tanto, se esperaría que lo hasta acá hecho, pueda encontrar nuevos líderes que acompañen a los ya presentes o que los releven para oxigenar la tarea.

\section{En los espacios}

La resignificación de los espacios del territorio, es uno de los objetivos encontrados en iniciativas como el Carnavalito. La reescritura de los significados de la infraestructura de sus barrios es la mayor lucha que se encuentra por los habitantes que participan de estas iniciativas.

La toma de las calles es un acto de resistencia y de presencia de la comunidad. Esto permite la apropiación y la identificación con su territorio. El arrebatarle las calles al anonimato, escribe un carácter familiar para aquel que ha dejado parte de su historia en sus espacios, y es por esto, que la labor de eventos como la caravana del Carnavalito, son idóneos para las comunidades que padecen de una violencia que genera estigmas en sus territorios. 
Aunque el Carnavalito es la representación de un esfuerzo enorme por ganar espacios, sería ideal que el estado reconociera la importancia de estas actividades y suministrara, dotara y subsidiara espacios donde se pudiese confluir para aportar a la comunidad.

Los líderes y lideresas comunitarios han logrado gestionar espacios en su territorio como: CELODIJE ${ }^{25}$, la sede de INTI TEKOA, la huerta comunitaria ${ }^{26}$, entre otros. Que son el símbolo materializado de esos ideales de comunidad por los que ellos se comprometen todos los días.

\section{En canales y flujos de la comunicación}

Para un esfuerzo enorme como el encontrado en esta comunidad se esperaría que se pudiese encontrar una amplia lista de referencias en una clase de biblioteca que pudiese ser de acceso a la comunidad en general o que se contase con una amplia divulgación, para que se pudiese reconocer aún más este proceso. Pero acá hemos encontrado una de las dificultades que se buscan sobrellevar por parte de los gestores comunitarios.

La comunicación con la comunidad, es uno de los puentes que se espera construir a través de procesos comunicacionales enrutados hacia una meta clara y es la de vincular más a la comunidad con las iniciativas de las instituciones del sector.

El uso de canales de comunicación más tradicionales, como el vos a vos, han ayudado a crear una cadena fuerte entre los gestores de las actividades territoriales y han desarrollado fluidez en los lazos comunicacionales de los usuarios de éstos. Pero, con estos canales se aprecian limitaciones cuando lo que se busca es llegar a círculos comunitarios más amplios. Es, por tanto, que se esperaría que se abordaran canales no tan tradicionales como los digitales en la divulgación de las actividades comunitarias, para lograr una mayor cobertura y un mejor contacto con los integrantes del territorio.

\section{Líneas de acción}

En este punto, podemos entender que se han llegado a reconocer algunos elementos que podrían aportar positivamente a las conclusiones encontradas a través del recorrido realizado por la aproximación que acá se ha documentado. Estos elementos fungen como las líneas de acción, que han sido concebidas en la conjunción de las voces encontradas en el territorio y

\footnotetext{
${ }^{25}$ Casa comunalpara uso de la comunidad. Cuenta con salas para reuniones, presentaciones de talleres y estudio de grabación.

${ }^{26}$ Espacio concedido por la junta de vecinos del barrio Caracolí de Ciudad Bolívar, donde se practican talleres de huerta y cultivo.
} 
que se toman como las herramientas que puedan aportar a los deseos y expectativas de los integrantes de la comunidad y que a continuación se presentan

- Establecer espacios adecuados para incentivar y aprovechar la disposición de los miembros de la comunidad.

- Encuentro de voluntades comunitarias en pro de generar nuevos espacios para la construcción de escenarios tanto físicos como simbólicos que contribuyan a la comunidad.

- Establecer puentes entre las instituciones de educación superior y los integrantes de la comunidad.

- Fomentar el aporte a la comunidad por parte de los integrantes del territorio que ya cuentan con una formación profesional o que se encuentran en ese proceso.

- Generar espacios de gestión y formar a las lideresas para que se les asigne un lugar de orientadoras dentro de la realidad de la comunidad.

- Mostrar las actividades que se están desarrollando y buscar enlazarlas con propuestas de instituciones que aporten al trabajo en conjunto.

- Fomentar actividades y espacios para el despliegue de los aportes de los integrantes de la comunidad que deseen participar de esta construcción.

- Generar un repositorio en donde se puedan llegar a ubicar las memorias de las experiencias de procesos comunitarios.

- Generar espacios de intercambio de saberes de los miembros de la comunidad.

- Formar en el aprovechamiento de los canales dispuestos para el contacto con la comunidad, generando contenidos que puedan instruir en aportes a la comunidad.

- Generar contenidos que ayuden a la divulgación de las actividades adelantadas por entidades de integrantes de la comunidad, como el Carnavalito.

- Buscar visibilizar las actividades de las entidades territoriales que muchas veces se desestiman por falta de conocimiento de las mismas.

- Generar una reconstrucción comunicacional que ayude a deconstruir estructuras lingüísticas y que procuren la construcción de nuevos conceptos positivos para la comunidad.

- Generar espacios de divulgación de las actividades de la población que, a modo de voz de la comunidad, generan una postura de resistencia ante esta violencia y con un lenguaje que no invite a prácticas que atenten contra miembros de la comunidad. Todo esto con mensajes de inclusión y construcción. 
- Procurar el uso de canales para transmitir información de manera más eficiente a los miembros de la comunidad y establecer usos más efectivos para los medios, que ya se usan, para comunicarse entre los miembros de la comunidad.

- Generar canales que divulguen las actividades de las entidades y que de igual forma establezcan puentes que acerquen a la comunidad y las entidades.

- Formar a los miembros del territorio en herramientas que faciliten el establecimiento de contacto con la comunidad.

- Fomentar el intercambio de experiencias que transmitan estrategias que ayuden a la gestión de actividades sin las dependencias de instituciones oficiales.

- Fomentar procesos de cambio en los sentidos que circulan dentro del territorio y buscar que se generen más espacios como los que ya se han construido para continuar con este proceso.

- Abordar el uso de canales digitales para la divulgación de las actividades comunitarias, para lograr una mayor cobertura y un mejor contacto con los integrantes del territorio.

- Encontrar y formar a nuevos líderes, que acompañen a los ya presentes o que los releven para oxigenar la tarea.

- Buscar que el estado reconozca la importancia de actividades desarrolladas en el territorio, reconociendo su independencia y que este suministre, dote y subsidie espacios donde se pueda confluir para aportar a la comunidad.

- Plantear estrategias para que las comunicaciones de las instituciones del sector estén dirigidas de manera más atractiva y eficiente a los niños de la comunidad y hacia sus acudientes. 


\section{CAPITULO 3}

\section{Mi proceso. Unas comillas aparte}

Lo que en principio se había pensado para proponer y lo que al final se materializó.

Bueno yo pienso que una manera de intervenir positivamente acá en el territorio es generando estos talleres que ayuden a la comunidad a interpretar otro punto de vista, a interpretar otra realidad que es posible en la misma comunidad. Entrevista a Camilo Viloria (Viloria, 2020), tallerista de Memoria en Video y líder juvenil.

La primera propuesta que surgió para apoyar el Carnavalito por la vida y el amor fue hacer un corto documental con el material audiovisual colectado en varios espacios de presentación de la fiesta popular. La justificación inicial era enfocarse en la difusión del evento con un producto hecho por personas con destreza en la producción de estos contenidos, pero ajenas al espacio del territorio. Se alcanzó a avanzar en esta propuesta y se tuvo como la meta buscada por mucho tiempo, pero la dificultad para la consecución de un editor para el material audiovisual empezó a postergar esta idea. Tiempo que sirvió para tomar una pausa y evaluar si lo antes mencionado suplía el trabajo de fondo y la visión plangesquiana de la intervención en el territorio.

Tras una evaluación notamos que el entregar un producto que facilite la exhibición del Carnavalito ante entidades ajenas al espacio territorial no cumple con la propuesta de intervención transformadora. El llegar a entregar un producto, aunque este cuente con un gran trabajo de elaboración, no enriquece en gran medida a las dinámicas de la comunidad. Esta propuesta carecía de nutrición en la construcción de territorio y no dotaba de acción al actor de las colectividades.

Fue entonces cuando se replanteó la acción transformadora y surgió la propuesta de los Talleres de Memoria en Video, en los que se seguía tomando la producción audiovisual ya no como un producto final sino como la excusa para generar espacios de formación para los actores de los colectivos. Con esta nueva propuesta se utilizaban los espacios de formación para formular diálogos en torno a situaciones reales del territorio y sobre ese intercambio de saberes edificar competencias comunitarias tales como la identidad, la ciudadanía y el empoderamiento, entre otras. Ya con este ejercicio se podía aportar al fortalecimiento del accionar político de los actores del territorio, pues la producción de contenidos que hablen del 
territorio desde las voces de los mismos habitantes de la comunidad es la democratización de la construcción de los sentidos que circulan en la palabra pública.

Ya, a estas alturas, yo ya no estaba como un observador que entra a la fiesta, sino que ya podía ayudar con mis conocimientos. El poder encontrar espacios para aportar con mis saberes a la comunidad fue un motivador personal que daba lugar a reconocer otro punto de vista del territorio.

El esbozar un plan de acción y desarrollarlo en el territorio es ser parte del entramado del movimiento, es ser parte de las dinámicas del territorio mismo.

\section{PLANIFICACIÓN Y GESTIÓN}

“...la comunicación es siempre un encuentro sociocultural, pero no un encuentro cualquiera, sino uno que "enactúa", que hace emerger nuevos mundos, nuevas realidades.” Sandra Massoni (Massoni, 2017)

\section{Estrategia de desarrollo}

Para darle continuidad al proceso de transformación en el territorio donde se lleva a cabo el Carnavalito por la vida y el amor y con el sustento de lo encontrado en el diagnóstico comunicacional, optamos por apoyarnos en la adecuada guía del Manual Sembrando mi tierra de futuro (Ceraso, et al, 2007) al tomarlo como una fuente que nos dotó con los conceptos necesarios para entender que un proceso comunitario no se detiene solo en el aproximarse a las comunidades y al territorio, sino que además podemos utilizar lo encontrado en esas aproximaciones para generar proyectos que potencien la comunidad o refuercen lo que se encuentre débil.

Con la matriz de estrategia de desarrollo, un genial instrumento de orientación para los procesos de planificación y gestión comunitaria, pudimos establecer la estructura de lo que se encontró y hacia a donde nos queremos proyectar. Con esta matriz se puede reconocer, del contexto en que queremos intervenir:

-Las problemáticas

-Las causas de estas

-Las consecuencias de las mismas

Encontramos también que, para impulsar una iniciativa de desarrollo, en nuestra comunidad y territorio, se tiene que establecer una estrategia de desarrollo, la cual tiene tres grandes componentes:

-Situación inicial (diagnóstico)

-Situación futura si no se genera una intervención (pronóstico) 
-Situación deseada (objetivo de desarrollo)

El camino entre la situación inicial y la situación deseada se llama estrategia de desarrollo, que es el conjunto de varios proyectos de desarrollo. Estos a su vez son diferentes unidades creadas y denominadas cada una como un proyecto, que es una organización de actividades para alcanzar objetivos propuestos. Estos objetivos responden a las necesidades reconocidas.

La situación inicial nos habla de los resultados de la aproximación inicial a la comunidad y el territorio y sirven de punto de partida para la elaboración de la estrategia de desarrollo.

La situación futura es la anticipación a lo que se decantará en la comunidad o territorio de no realizarse una adecuada intervención. Se estima que sea a un plazo acordado por los interventores, aunque es recomendable que sea proyectada a 5 o 10 años. Esta proyección tiene que estar sustentada por lo encontrado en el diagnóstico y por la apreciación de integrantes de la comunidad e interventores, quienes, con su conocimiento del territorio, aportan elementos que pueden trascender los alcances del diagnóstico, ya que con su conocimiento pueden contribuir a la construcción del territorio.

La situación deseada es la meta última de la estrategia de desarrollo. Es donde se culminarán los esfuerzos de las actividades realizadas. Estas, al igual que el contenido de la situación futura, se tiene que sustentar en lo encontrado en el diagnóstico y los deseos y planteamientos de los integrantes e interventores de la comunidad.

El proyecto de desarrollo cuenta con diferentes etapas:

1. la identificación del proyecto (guía inicial la necesidad detectada)

2. la formulación y el análisis de factibilidad

3. la gestión y el financiamiento

4. la ejecución del proyecto

5. la fase de funcionamiento

6. el seguimiento y la evaluación

\section{Figura 9}

GRÁFICA MATRIZ DE ESTRATEGIA DE DESARROLLO 


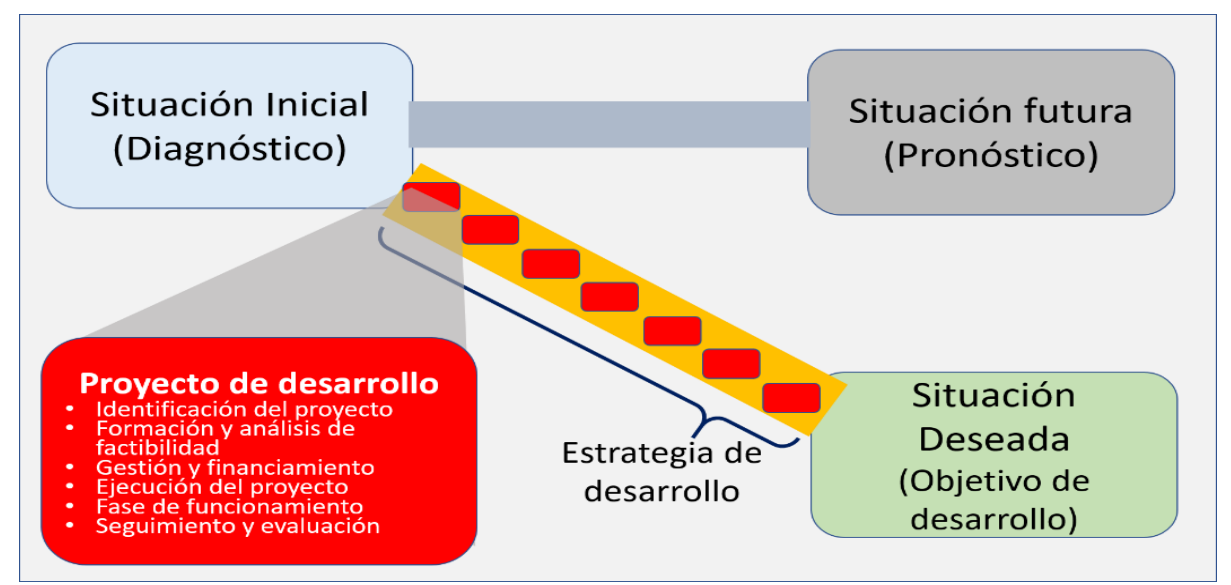

Ilustración de elaboración propia basada en la descripción de estrategias de desarrollo de (Ceraso, et al, 2007).

Una vez aprehendimos las bondades de este instrumento, para el ejercicio de la aplicación del mismo en el territorio de los barrios de las UPZ 69 y 70 del sur de Bogotá, donde se desarrolla el Carnavalito, tomamos como guía el trabajo de Fernando Flórez en "Estrategia de procesos comunicacionales, para transformar las situaciones problemáticas de vida, de la Comunidad LGBT del municipio de Itagüí en Medellín, Colombia.” (Flórez, 2019), quien describió la aplicación de la estrategia de desarrollo en las siguientes palabras:

En ese orden, la Estrategia se construyó teniendo en cuenta las particularidad es que presenta el territorio y la comunidad (los datos duros obtenidos del Diagnóstico); cruzados con los Valores Subjetivos de la Comunidad (resultado de: recorrer el territorio, interactuar con las personas y conocer su cultura); lo que nos permitió Pronosticar la situación futura que es cómo sería la situación de la Com LGBT en 5 o 10 años sin haberla intervenido para transformarla; lo que dio paso a identificar elementos potenciales de Desarrollo Endógenos, en búsqueda de la transformación de las realidades negativas y mejoramiento o mantenimiento de las realidades positivas; lo que coincidió con la utopía o situación deseada de la Com LGBT (Objetivo de Desarrollo Endógeno). Pag, 130.

Guiados por Fernando Flórez (Flórez, 2019), aplicamos la matriz de la estrategia de procesos comunicacionales, utilizando a la comunicación como elemento transversal a las realidades y entendiendo que utilizando esta transversalidad podemos construir una estrategia de desarrollo próspera para la comunidad alreded or del Carnavalito. Los planteamientos consignados en las siguientes tablas dan cuenta de las charlas con miembros de la comunidad, sus opiniones acerca de la actualidad y el futuro del territorio. Tiempo en la 
comunidad, calles caminadas, preguntas directas en diálogos personales y conversaciones sueltas en espacios más distendidos, han intervenido en las proyecciones y conclusiones acá expresadas.

\section{Tabla 6}

MATRIZ DE LA ESTRATEGIA DE PROCESOS COMUNICACIONALES

\begin{tabular}{ll}
\hline \multicolumn{1}{c}{ Proceso } & \multicolumn{1}{c}{ Dimensión } \\
\hline Diagnóstico. & Realidad material y objetiva. \\
\hline $\begin{array}{l}\text { Identificación de los valores subjetivos de } \\
\text { la comunidad. }\end{array}$ & Realidad subjetiva de la comunidad. \\
\hline Pronóstico. & $\begin{array}{l}\text { Futuro no intervenido para la } \\
\text { Transformación. }\end{array}$ \\
\hline $\begin{array}{l}\text { Identificación de elementos potenciales de } \\
\text { desarrollo. }\end{array}$ & $\begin{array}{l}\text { Realidad por intervenir para la } \\
\text { transformación. }\end{array}$ \\
\hline Construcción de objetivo de desarrollo. & Futuro deseado \\
\hline $\begin{array}{l}\text { Planteamiento y elaboración de proyectos } \\
\text { de desarrollo. }\end{array}$ & $\begin{array}{l}\text { Planificación de la realidad para la } \\
\text { Transformación }\end{array}$ \\
\hline Ejecución de proyectos de desarrollo. & Gestión de la realidad para transformarla. \\
\hline
\end{tabular}

\section{Tabla 7}

MATRIZ DE REALIDAD MATERIAL Y OBJETIVA.

\section{Matriz de realidad material y objetiva}

La ciudad de Bogotá tiene una población de más de 8'200.000 personas, distribuidas en una extensión de territorio de $1775 \mathrm{~km}^{2}$.

La población de Bogotá se ha incrementado 2500\% desde 1938.

De los $1775 \mathrm{~km}^{2}, 307 \mathrm{~km}^{2}$ pertenecen a la superficie urbana, $170 \mathrm{~km}^{2}$ a la suburbana y $1298 \mathrm{~km}^{2}$ a la rural. Siendo el porcentaje de estas medidas el 17\%, el 9\% y el $73 \%$ respectivamente.

El territorio urbano está dividido en 19 localidades, siendo Ciudad Bolívar la número 19.

La localidad de Ciudad Bolívar cuenta con una extensión de $20,88 \mathrm{~km}^{2}$, con una población de 700.000 habitantes, que se estima es el 8,5\% de la población total de la ciudad de Bogotá.

La población de Ciudad Bolívar está distribuida en 49\% de hombres y 51\% mujeres. 
Ciudad Bolívar es la cuarta localidad de Bogotá con más población, detrás de Suba, Kennedy y Engativá.

Ciudad Bolívar, se divide en 8 UPZ.

Las UPZ \#70 Jerusalén y \#69 Ismael Perdomo, son las zonas del país que más recepciona desplazados por la violencia interna de Colombia.

Aunque los estratos de la población general de Bogotá tengan una representación para estrato 1 de $7 \%$, para estrato 2 de $33 \%$ y estrato 3 de $34 \%$, lo observado el Ciudad Bolívar es que para el estrato 1 el porcentaje es de $58 \%$, para estrato 2 de $27 \%$ y estrato 3 de $15 \%$, con $0 \%$ de estratos 4,5 y 6 . Esto hace evidente la diferencia socioeconómica que se tiene en comparación con la generalidad de la ciudad.

Aunque la ciudad de Bogotá se encuentra a 2600 metros sobre el nivel del mar, en promedio, la localidad de Ciudad Bolívar tiene una altimetría que se encuentra entre los 2650 y los 3100 metros sobre el nivel del mar. Considerando que la localidad, en su mayoría, se encuentra en una alta habitación de terrenos montañosos, que dificulta el acceso a la zona por su inclinación y la baja velocidad que esto implica para el transporte, se puede decir que la movilidad en esta zona es de una evidente dificultad. Sumado a lo anterior se tiene que tener en cuenta la deteriorada malla vial para accesos y tránsito por el territorio.

La temperatura anual promedio de la localidad es de 13 grados centígrados.

La localidad cuenta con 161 colegios, sedes de dos Universidades de formación técnica, tecnológica y profesional.

La localidad tiene dos hospitales, y veinte centros de atención medica primaria, básica y de atención inmediata.

\section{Tabla 8}

MATRIZ DE VALORES SUBJETIVOS DE LA COMUNIDAD

\section{Matriz de valores subjetivos de la comunidad}

La localidad de Ciudad Bolívar fue reconocida oficialmente como parte de Bogotá a partir de la constitución colombiana de 1991. Aunque sus primeros grandes barrios fueron fundados en los años 50's. Se estima que la localidad cuenta con una arquitectura de construcciones recientes.

Los constantes asentamientos de familias provenientes del desplazamiento del conflicto 
armado del país y la evidente composición socioeconómica, que en su mayoría son de los estratos 1 y 2 , hacen que se produzcan familias jóvenes y de escasos recursos y por tanto un alto número de integrantes de la comunidad con una media de edad joven y vulnerable.

Las dificultades para la ubicación laboral y las escasas oportunidades de formación profesional generan una alta tasa de trabajo informal dentro de la población.

La localidad presenta unos altos índices de violencia e inseguridad. Elemento que es potencializado por los estereotipos que circulan en el lenguaje de la comunidad.

Los sentidos que circulan muchas veces son exagerados por los medios de comunicación y por leyendas urbanas que han sido construidas por rumores o que fueron episodios aislados que se acrecentaron.

La presencia de diferentes grupos armados ilegales ha generado zozobra a través de los años y se evidencia en el temor que algunos habitantes del sector expresan acerca de grupos que se mueven en la oscuridad y que asesinan y delinquen sin una clara atención a estas calamidades de la población por parte del estado.

Existen unos estereotipos marcados para los habitantes de la localidad, incluso replicados por ellos mismos, cargados de elementos negativos para la construcción de una identidad comunitaria que les sea beneficiosa.

Existe un creciente interés en el trabajo por la comunidad por parte de los integrantes de las instituciones de trabajo social del territorio.

La voluntad y el empoderamiento de los habitantes del sector, hace evidente que se tengan unas propuestas mucho más elaboradas, en comparación a las propuestas observadas en décadas anteriores.

La formación profesional y la instrucción recibida por los diferentes programas de las instituciones del territorio, han dado herramientas a los nuevos líderes de la comunidad.

Se nota una gran entrega a los proyectos de la comunidad por parte de los participantes de las instituciones del territorio, que muchas veces incluyen a integrantes de sus familias en las tareas que ya realizan heredando-transmitiendo conocimiento.

El más alto número de mujeres y la escasa oferta laboral, que agobia no solo a la localidad sino al país completo, hace que muchas de ellas, siendo cabezas de hogar, tengan trabajos informales para asegurar un ingreso para sus familias. Trabajos que no cuentan con prestaciones sociales ni seguros médicos. La demanda de tiempo que generan estos trabajos informales, al igual que los formales, sumado a la dificultad de 
acceso al sector hace que muchas veces los hijos de estas familias permanezcan por mucho tiempo solos y en las calles. Para abordar estas dificultades las mismas mujeres han creado proyectos como los de Madres Comunitarias, ahora regulado por el gobierno distrital. Ubicando a las mujeres, junto a los niños como uno de los actores principales del territorio.

La continuidad a través de los años y el férreo proceso y discurso de los integrantes de las diferentes instituciones de la comunidad, hacen que estos generen y reproduzcan nuevos sentidos y por tanto nuevos discursos que circulan en el territorio.

El trabajo previo de las instituciones del territorio ha generado buenas bases para nuevas intervenciones y propuestas para la comunidad, pues evidencian un alto sentido crítico y propositivo que sirven de cimientos para los nuevos proyectos.

Aunque no ha existido un presente apoyo de los gobiernos nacional ni distrital, los integrantes de las instituciones territoriales han aprendido a generar sus propios procesos con mecánicas de sustento propio. Elemento que las ha hecho fuertemente independientes de intereses de administraciones particulares.

Nunca ha dejad o de ser una realidad que el rechazo y la indiferencia por parte de un amplio número de los pobladores del sector, hacen mella en las voluntades de los gestores de iniciativas comunitarias, pero esto ha generado que estas voluntades se consoliden a través de los años. Pero también es una realidad que muchos de los gestores con los que iniciaron gran parte de los proyectos de la zona, ya no continúan más con estos, pues el desgaste se ha hecho presente en estas dinámicas.

\section{Tabla 9}

MATRIZ PRONÓSTICO

\section{Pronóstico (futuro estimado, no intervenido para la transformación)}

Las iniciativas que se han gestado por años llegarán a su fin por falta de apoyo.

Los gobiernos nacional y distrital seguirán ignorando estos procesos y desistiendo de apoyarlos.

Los líderes comunitarios irán desapareciendo por agotamiento, desplazamiento, rechazo o por falta de interés.

Actividades como el Carnavalito desaparecerán si las iniciativas no son acogidas por las exigencias para el desarrollo de las tareas de las madres comunitarias. 
Los grupos armados al margen de la ley se apoderarán de los espacios territoriales ganados por las actividades de los grupos de instituciones sociales del territorio.

La violencia e inseguridad seguirán y se intensificarán, potencializadas por una escasa oferta de oportunidades académicas y laborales que les ayuden a mejorar la calidad de vida a los habitantes del sector.

Los estereotipos que circulan por la ciudadanía seguirán estableciéndose en la cotidianidad de los habitantes de Bogotá, reforzando la imagen negativa de los habitantes de la localidad de Ciudad Bolívar.

La pérdida del espacio ganado por las instituciones, que en ese tiempo estarán ausentes, generará una ruptura en la conexión de los integrantes del territorio, pues no se podrán generar interacciones que establezcan procesos en conjunto dentro de la comunidad. La desigualdad socioeconómica seguirá aumentando en contra de la calidad de vida de los habitantes del sector.

La desconexión de la comunidad y entes gubernamentales abrirá aún más la brecha que ya se tiene entre ellos.

Puede que las iniciativas comunitarias se empiecen a desmontar paulatinamente a causa de los obstáculos presentados en diferentes frentes, como lo son los comunitarios, los económicos, los políticos, entre otros.

La desidia y el desinterés por parte de las nuevas generaciones del sector interrumpirán la continuidad de los procesos de muchos años de los gestores comunitarios.

Los niños del sector aumentarán su vulnerabilidad, pues a la ausencia del estado se sumarán la falta de la presencia de entidades comunitarias del territorio.

\section{Tabla 10}

MATRIZ DE IDENTIFICACIÓN DE ELEMENTOS POTENCIALES DE DESARROLLO / REALIDAD POR INTERVENIR PARA LA TRANSFORMACIÓN

\section{Realidad por intervenir para la transformación}

Los cimientos establecidos por la labor de años de las instituciones sociales del territorio, favorecen las nuevas propuestas de intervención, ya que llegan a una población con unos discursos diferentes a los que se encontraron las primeras intervenciones en el territorio. Esto nos ayuda a acortar camino en las metas que nos tracemos para contribuir en la construcción de esa identidad comunitaria esperada para 
el territorio.

El encuentro de voluntades para la intervención social es algo que se hace presente y por tanto es positivo para la construcción de la comunidad.

Iniciativas ejecutadas por años han dado experticia a los líderes de proyectos dentro del territorio. Esto ayuda a hacer más efectiva y eficiente la gestión de las propuestas que se busque germinar en la comunidad.

Los medios de comunicación tradicionalmente utilizados por los líderes de la comunidad, principalmente el voz a voz, han tenido una serie de limitaciones, pero son particularmente efectivos en sus tareas básicas. El uso tradicional conlleva a que se tengan líneas establecidas como prioritarias. Los grupos en plataformas como WhatsApp ayudan a extender el mensaje a miembros más alejados dentro de los gestores. Es esperable que estos canales se amplíen y se fortalezcan los usos y sus contenidos para poder reducir el esfuerzo invertido en el alcance e invertir esa fuerza en los contenidos que por estos canales circulen.

Instituciones como las Madres Comunitarias e Inti Tekoa, entre otras tantas, fungen como emblemas dentro del territorio. Estas invitan a movilizarse por el sector y desarrollar actividades para el crecimiento de la comunidad. Es, por tanto, esperable que estos emblemas se fortalezcan y repliquen en otros lugares del territorio para de esa forma, poder ir apropiando los espacios a favor de la comunidad.

Los puentes establecidos con instituciones de educación superior, ONG's, y organismos internacionales, ayudan a difundir las actividades y propuestas por, en y para el territorio y su comunidad.

Nuevos formatos en la administración pública de la ciudad pueden crear puentes para que se aporte a la gestión de actividades de interés social.

La inclusión de nuevos profesionales que aporten a la comunidad, conlleva a una mejor calidad en las intervenciones, esto sumado a que los líderes encontrados en las nuevas generaciones cuentan con posturas más críticas y discursos más entrañados en los sentidos constructivos para su territorio, genera un factor humano con mejores competencias disponibles para los proyectos sociales.

El encuentro de fraternidades entre las instituciones sociales que se encuentran en la comunidad, contribuye a que se puedan germinar proyectos conjuntos sin que se presenten mayores dificultades en el empalme de estas potencialidades. 
Puentes digitales de comunicación que aún no han sido aprovechados en una buena proporción, se presentan como una oportunidad de crecimiento para las aspiraciones y los deseos de la comunidad.

Un evidente cambio en los discursos y los sentidos que circulan en la comunidad, ayudan a proyectarse con una mayor esperanza y expectativa por parte de los gestores de proyectos, que encuentran en estos contenidos un aliciente que fortalece la tarea realizada.

Material comunicacional de eventos realizados en múltiples actividades, se encuentran dispersos y pueden llegar a ser parte del repositorio de lo que será el banco de memorias de eventos como el Carnavalito. La construcción de una identidad comunitaria podrá tener a este repositorio como eje principal, como su bastión.

El uso de unos buenos recursos en manejo de herramientas digitales por parte de algunos líderes comunitarios, se presenta como una oportunidad de implementación en materia de producción digital para actividades que ellos realizan en el sector.

\section{Tabla 11}

MATRIZ DE CONSTRUCCIÓN DE OBJETIVO DE DESARROLLO /FUTURO DESEADO

\section{Futuro deseado}

La continuidad de las iniciativas realizadas en el territorio potencializadas.

El establecimiento de una política de apoyo a la gestión de los procesos sociales gestados por las instituciones comunitarias del territorio.

Una nueva generación de líderes, que recepcionen y apoyen los esfuerzos de los grupos de líderes tradicionales de la comunidad, que ya necesiten un espacio de oxigenación y de recarga.

Un Carnavalito sustentado en la identidad comunitaria y que se procure por la iniciativa de los mismos integrantes de la comunidad.

El territorio completo como sentir propio por la comunidad. Que sea parte de su identidad y su arraigo por el sector. Que se incluya dentro de la historia de vida de los habitantes del territorio.

Que las nuevas oportunidades laborales y de formación ayuden a reducir la delincuencia y la inseguridad en el sector, ya que, como consecuencia de estas oportunidades, los jóvenes y familias del sector encuentren nuevas y positivas opciones 
de desarrollo y no tengan que elegir, como opción para su supervivencia, a los actos delictivos.

Un cambio positivo en las representaciones sociales de los habitantes de la localidad de Ciudad Bolívar, sustentadas en procesos llevados a cabo por la comunidad y evidenciados en sus habitantes.

Nuevos espacios comunitarios que aporten a la construcción de esa institucionalidad del territorio y desarrollen esa identidad comunitaria que intervenga positivamente en sus habitantes.

La calidad de vida de los habitantes del sector mejora considerablemente, disminuyendo la brecha socioeconómica que los ha aquejado por tanto tiempo.

Una comunidad mucho más atenta a la propia gestión de su territorio. Conectada con las instituciones gubernamentales y veedora de las mismas.

Unas iniciativas construidas, desarrolladas y fortalecidas por los actos de la comunidad, con un apoyo de instituciones gubernamentales y con una autonomía política y económica que pueda hacer que estas iniciativas no entren dentro del juego de componendas burocráticas de algunos sectores de la política.

Unas nuevas generaciones que no solo releven a las anteriores, sino que a su vez forme a las generaciones venideras, creando ese arraigo por el territorio a través del tiempo.

Una comunidad fortalecida por unas políticas sociales oportunas para las necesidades del sector y unas instituciones comunitarias atentas a intervenir en lugares específicos de la comunidad.

\section{Planteamiento y elaboración de proyecto de desarrollo}

Como punto de partida para nuestra propuesta de proyecto de desarrollo en la comunidad alrededor del Carnavalito, tomamos las líneas de acción que han sido el resultado de nuestra aproximación diagnóstica, la cuál ha sido descrita en la primera parte de este documento. Considerando las proyecciones y lo dialogado con miembros del territorio, tomamos las líneas de acción y reflexionamos sobre propuestas para después presentar las ideas a líderes de la comunidad.

Estas líneas de acción, acá se han de presentar filtradas por grupos de relación y jerarquizadas para entender de mejor forma el camino más adecuado que tomamos para el desarrollo de nuestro proyecto. 
Los grupos de propuestas de líneas de acción que se conformaron tienen como propósito responder a particularidades que las asocian y con esto poder elaborar propuestas que respondan a una o varias de estas por la proximidad que tengan.

Los grupos de propuestas de líneas de acción para la comunidad y el territorio alrededor del Carnavalito, derivadas del análisis de familiaridad se relacionan con:

- Aspectos de la comunicación

- Relacionados con la formación y capacitación

- Espacios comunitarios

- El fomento y la promoción

\section{Aspectos de la comunicación}

De estas propuestas de líneas de acción hemos encontrado dos vertientes. Las relacionadas con los canales y contenidos y las relacionadas con los procesos.

Canales y contenidos

- Generar un repositorio en donde se puedan llegar a ubicar las memorias de las experiencias de procesos comunitarios.

- Generar contenidos que ayuden a la divulgación de las actividades adelantadas por entidades de integrantes de la comunidad, como el Carnavalito.

- Procurar el uso de canales para transmitir información de manera más eficiente a los miembros de la comunidad y establecer usos más efectivos para los medios que ya se usan para comunicarse entre los miembros de la comunidad.

- Generar canales que divulguen las actividades de las entidades y que de igual forma establezcan puentes que acerquen a la comunidad y las entidades.

- Abordar el uso de canales digitales para la divulgación de las actividades comunitarias, para lograr una mayor cobertura y un mejor contacto con los integrantes del territorio.

Procesos

- Mostrar las actividades que se están desarrollando y buscar enlazarlas con propuestas de instituciones que aporten al trabajo en conjunto.

- Instruir en el aprovechamiento de los canales dispuestos para el contacto con la comunidad, generando contenidos que puedan incentivar en aportes a la comunidad. 
- Buscar visibilizar las actividades de las entidades territoriales que muchas veces se desestiman por falta de conocimiento de las mismas.

- Generar una reconstrucción comunicacional que ayude a deconstruir estructuras lingüísticas y que procuren la construcción de nuevos conceptos positivos para la comunidad.

- Plantear estrategias para que las comunicaciones de las instituciones del sector estén dirigidas de manera más atractiva y eficiente a los niños de la comunidad y hacia sus acudientes.

- Establecer puentes entre las instituciones de educación superior y los integrantes de la comunidad.

\section{Relacionados con la formación y capacitación}

- Encontrar y formar a nuevos líderes, que acompañen a los ya presentes o que los releven para oxigenar la tarea.

- Formar a los miembros de la comunidad en herramientas que faciliten el establecimiento de contacto entre miembros del territorio.

\section{Espacios comunitarios}

En este apartado de propuestas de líneas de acción también encontramos una subdivisión:

- Espacios relacionados con la Infraestructura

- Espacios simbólicos

Espacios relacionados con la Infraestructura

- Establecer espacios adecuados para incentivar y aprovechar la disposición de los miembros de la comunidad.

- Encuentro de voluntades comunitarias en pro de generar nuevos espacios para la construcción de escenarios tanto físicos como simbólicos que contribuyan a la comunidad.

Espacios simbólicos

- Generar espacios de gestión y formar a las lideresas para que se les asigne un lugar de orientadoras dentro de la realidad de la comunidad.

- Generar espacios de intercambio de saberes de los miembros de la comunidad.

- Generar espacios de divulgación de las actividades de la población que, a modo de voz de la comunidad, generan una postura de resistencia ante esta violencia y con un 
lenguaje que no invite a prácticas que atenten contra miembros de la comunidad. Todo esto con mensajes de inclusión y construcción.

\section{El fomento y la promoción}

En este apartado de propuestas de líneas de acción encontramos que se puede presentar fomento y/o promoción hacia dos grupos definidos de personas:

- Integrantes de la comunidad en general

- Líderes de la comunidad

Integrantes de la comunidad en general

- Fomentar el aporte a la comunidad por parte de los integrantes del territorio que ya cuentan con una formación profesional o que se encuentran en ese proceso.

- Fomentar actividades y espacios para el despliegue de los aportes de los integrantes de la comunidad que deseen participar de esta construcción.

- Fomentar el intercambio de experiencias que transmitan estrategias que ayuden a la gestión de actividades sin las dependencias de instituciones oficiales.

Líderes de la comunidad

- Fomentar procesos de cambio en los sentidos que circulan dentro del territorio y buscar que se generen más espacios como los que ya se han construido para continuar con este proceso.

- Buscar que el Estado reconozca la importancia de actividades desarrolladas en el territorio y que este suministre, dote y subsidie espacios donde se pueda confluir para aportar a la comunidad.

Una vez establecidas todas las figuras necesarias para la composición de nuestra estrategia de desarrollo y entendiendo las presentes necesidades y proyecciones de nuestra comunidad, continuamos con el planteamiento de la idea de proyecto de desarrollo en el territorio donde se presenta el Carnavalito por la vida y el amor. Las proyecciones a futuro, las iniciativas de transformación, el deseo de reconocer lo que ya se ha trabajado y la invitación a la participación en proyectos de crecimiento, son la concertación de las voces de los niños, los jóvenes, las mujeres y los líderes comunitarios que han plasmado sus aportes en la propuesta acá realizada, reconociendo esas necesidades devenidas en líneas de acción. 


\section{La identificación del proyecto}

Teniendo en cuenta las necesidades reconocidas al recorrer el territorio, participando en diferentes espacios comunitarios de los barrios de las UPZ 69 y 70 de Ciudad Bolívar y siendo parte de la gestión de procesos colectivos, pudimos reconocer que contamos con las bases necesarias para establecer una propuesta que busca abordar estas necesidades y sacar adelante los ideales establecidos en el Objetivo de Desarrollo. Aunque es nuestro deseo utópico salir avante con todas las propuestas al mismo tiempo, tenemos que ser realistas a la hora de afrontar esta propuesta pues, aunque se coloque todo el empeño en estas iniciativas la realidad de nuestro territorio no se va a modificar de un día para otro, ni con una sola intervención. Pero, si no empezamos nunca, nunca vamos a avanzar. Y es por tanto que se buscó plantear una propuesta que abordara la transversalidad de las líneas de acción encontradas en la fase diagnóstica, buscando con esto que se presentara una vinculación y un crecimiento con el territorio y sus deseos, más que tener una lista de chequeo de productos para ir tachando como entregados. Así surgió la propuesta de abordar la comunicación de los procesos de iniciativas de los colectivos del territorio abordando canales digitales, pero desde una producción directa por miembros de la propia comunidad, siendo el fin último de esta iniciativa y el verdadero trasfond o del proyecto mismo el formar líderes no solo con competencias técnicas en producción de contenidos audiovisuales, sino que estos mismos desarrollen en su proceso de aprend er y aprehender un empoderamiento y prospectiva de contribución a su comunidad. Reconociend o en el tránsito de este proceso que el crecimiento de la comunidad se da en la medida que sus miembros cuenten con unas competencias relacionadas con el aporte social y la transformación a través del cambio de sentidos de sus realidades.

\section{Título del proyecto}

Talleres Memoria en Video. Formación comunitaria en producción de contenidos audiovisuales, para el fomento de la identidad comunitaria y la construcción de territorio.

\section{Descripción de proyecto}

La importancia de este proyecto radica en la transversalidad de su acción, pues aborda la formación de un grupo de jóvenes líderes comunitarios de los barrios de las UPZ 69 y 70 de Ciudad Bolívar, con quienes se tratan las problematizaciones de su comunidad. Con este ejercicio se busca que se adelanten visiones y voces de cambio para el territorio. La ciudadanía y la identidad comunitaria son las construcciones hacia las que se apuntan las intervenciones acá desarrolladas, ya que estas acarrean sentidos de apropiación y 
participación de los miembros que las desplieguen. Unos sujetos de cambio mediados por la comunidad. El desarrollo de estas competencias son el fin último del ejercicio de este proyecto y para conseguirlo se ha hecho uso de espacios de intercambio y de diálogo con jóvenes líderes de la comunidad. Espacios en los cuales se dialoga acerca de la realidad del territorio y se plantean posibles soluciones y proyecciones nacidas del territorio mismo.

Estos diálogos se encuentran inmersos en el marco de los espacios de formación de producción de contenid os audiovisuales, que desarrollan la implementación de herramientas comunicacionales para la difusión de las actividades llevadas a cabo por las instituciones comunitarias del territorio.

La comunicación como agente fundamental en la transformación, aporta desde las técnicas de planificación y gestión de procesos comunicacionales, ese movimiento de avanzada, necesario para que la comunidad obtenga un poderoso instrumento de construcción de comunidad. El aporte de habitantes y gestores del territorio, ha facilitado el desarrollo de esta iniciativa social.

\section{Ente ejecutor}

\section{Corporación INTI TEKOA}

Sede INTI TEKOA, ubicada en la calle76 a sur \#68-27. Barrio Caracolí, Localidad de Ciudad Bolívar, Bogotá, Colombia.

Facilidades físicas con las que cuenta: un espacio propio, con disposición al uso para la comunidad. Adecuado con equipos de cómputo con los programas necesarios para la formación y producción de contenidos audiovisuales generados por y para la comunidad.

Experiencia en la realización de trabajos similares: Más de quince años de trabajos con la comunidad hace que se tenga una experticia en la dirección de proyectos por parte de los líderes de la corporación y del profesional instructor a cargo del espacio.

\section{Diagnóstico}

La comunidad alrededor del Carnavalito por la vida y el amor, es una población con una marcada diferencia socio-económica, en relación a la media de la ciudad de Bogotá. Cuenta con la presencia de instituciones de trabajo social, con una larga experiencia en procesos comunitarios.

Ubicada en la localidad de Ciudad Bolívar, al sur de la ciudad de Bogotá, esta es una de las localidades más recientemente reconocida como parte de la ciudad de Bogotá, después de la constitución nacional de 1991. Con uno de los indicadores de violencia e inseguridad más 
altos de la ciudad, se ha luchado por cambiar esta realidad para mejorar la calidad de vida de los habitantes del territorio.

Con más de 700.000 habitantes, la localidad se encuentra a cargo del gobierno distrital de la ciudad de Bogotá, quien, por decreto del alcalde de turno, designa a un alcalde menor que estará a cargo de la administración política de la localidad.

Una continua estigmatización de la comunidad que habita el territorio de Ciudad Bolívar, por parte de los habitantes de la ciudad de Bogotá, ha generado que la idea que circula de la localidad sea de improntas negativas que se transforman en representaciones sociales, en sentidos que crean una imagen a priori no solo para los ojos externos a la localidad sino para los mismos habitantes de este territorio, ya que reviste de unas actitudes y unos adjetivos para las personas sin siquiera conocer al sujeto en su realidad; discursos que se reproducen por los mismos habitantes de la comunidad y que generan una displicencia, una desidia, un desprendimiento por el territorio mismo y que devienen en un nivel cero de proyección en, para y por la comunidad.

Al observar dónde se sustentan los sentidos circundantes encontramos que lo que se guarda en las memorias de los pobladores y en los archivos tanto periodísticos como digitales de otros medios de comunicación, dan cuenta en su mayoría de estos actos violentos y segregadores relacionados con la comunidad.

Lo que se plantea en las nuevas visiones críticas de los habitantes del territorio no es la negación de episodios violentos, que los hubo y los sigue habiendo, no, lo que se plantea es que esto no es lo único que se acciona en estas colectividades; con lo que se cuenta en la actualidad es con iniciativas culturales, de formación, de transformación y proyección, de buenas voluntades, son parte de esas realidades vivas que se dan en el territorio y de lo que los medios de comunicación no dan cuenta y que por su escasa difusión los mismos habitantes del territorio desconocen.

El Carnavalito por la vida y el amor es una de esas iniciativas, nacidas del territorio mismo, que sostiene esas buenas voluntades y proyecciones para la comunidad de estos barrios del sur de Bogotá, pero que, aunque cuenta con una fuerza de una colectividad con anhelo de transformación, aun no explota el potencial proyectado para este evento de territorio.

Hemos hallado que la formación para los jóvenes líderes en competencias transformadoras, aunque está presente en espacios no formales, aun no se ha encontrado condensada en un sector que dirija estas formas de aprehender, vemos esto sumado a que además no se ha contado con una colectividad que se haga cargo de llevar el recuento de las 
memorias de lo trabajado en el territorio. Lo anterior, mirado a través del prisma de deseos de los actores de la comunidad, ha brindado espacio para reconocer y trabajar este vacío buscando la transformación.

\section{El problema}

La indiferencia del estado por las calamidades de los habitantes de la comunidad de las UPZ 69 y 70 de la localidad de Ciudad Bolívar, ha generado que algunos integrantes del mismo territorio se organicen en diferentes instituciones de trabajo social buscando mitigar esas dificultades. La protesta por la violencia sectorizada y ejecutada por grupos violentos, la recuperación del territorio para la comunidad, la carencia de servicios básicos, han sido parte de los temas que la misma comunidad ha buscado autogestionarse. El ejercicio de estas tareas, algunas continuadas por décadas, ha fomentado la apropiación de la intervención con proyectos en la misma comunidad y ha generado eventos insignias como el del Carnavalito. Este evento ha servido para la recuperación de las calles como acto político en favor de la comunidad. Quitándole lugar a la desidia y el desinterés en las calles del sector. La construcción de una identidad comunitaria para los habitantes del territorio, la construcción del tejido social, la habilitación de espacios para el fomento social, han sido algunos de los temas relacionados con las primeras iniciativas de las instituciones del territorio.

Pero, como es de esperarse, estos ejercicios en ocasiones resultan de escaso impacto en la comunidad y en múltiples ocasiones desgastantes para algunos gestores, quienes optan muchas veces por aplazar sus actividades comunitarias o con desistir de ellas, a consecuencia de largas jornadas de actividad que con frecuencia no se ven representadas directamente en la comunidad. Desgaste apenas esperable para cualquier intervención en cualquier grupo social humano.

Al concluir la aproximación diagnóstica hemos encontrado que uno de los grandes aportes de la iniciativa del Carnavalito, y su gran impacto en y por los participantes del mismo, ha sido el reforzar características propias del crecimiento de una comunidad, la apropiación, el fomento de la interacción con los vecinos al tomarse esa esfera pública y otras potencialidades de crecimiento, se observan al ver el volumen de participación y no por ver los números y dimensiones sino por reconocer el impacto de los niños de los jardines infantiles, de los padres y familiares de los niños, de las madres comunitarias y de integrantes de las instituciones hacedoras del evento que salen de su entropía y se toman las calles, se ve al escuchar los discursos de arraigo y el uso de los espacios públicos de los barrios para usos de fomento de la cultura y el deporte. La identificación por parte de los hacedores de la fiesta 
cultural es parte de esos logros obtenidos por el trabajo continuo en el territorio. Pero, es una gran sorpresa que los habitantes de la comunidad que no son parte de la producción del ejercicio del Carnavalito no sean parte de ese recuento de experiencias que enmarcan el impacto de este ejercicio colectivo. No necesariamente porque no han estado presentes en las manifestaciones ni porque no se reconozca que el hecho mismo de manifestarse en las calles ya es un acto de impacto territorial, sino porque no se hace evidente alguna colectividad ni agrupación permanente que sea parte de la injerencia en la activación y producción del Carnavalito, por tanto, es acá donde se reconoce que el mayor impacto de esta fiesta popular se da para los participantes de la gestión y la producción, pero que esa fuerza se reduce al aproximarse al resto de los habitantes del territorio. Ha sido parte del interés de esta aproximación reconocer y desarrollar espacios que propicien el encuentro más cercano entre el Carnavalito y los habitantes de la comunidad, esperando que se vuelva parte de los sentidos que circulan en ese encuentro del discurso cotidiano. La apropiación social como esa meta a seguir es a donde se ha apuntado con las propuestas desarrolladas en la presente aproximación.

Otra dificultad reconocida por los gestores de esta iniciativa colectiva es que la materialización de la memoria producto de años de trabajo continuo no se ha desarrollado, causando que el registro histórico de todo lo hecho quede casi que por completo en historias, en discursos entre los mismos hacedores del evento. Aunque no es para nada negativo que la historia viva en la memoria personal de estos hacedores, lo que se espera es que la memoria de lo hecho por el Carnavalito se vuelva colectiva y que pueda llegar a ser consultada incluso por aquellos que no son parte del espacio territorial o comunitario del Carnavalito, y, con obviedad, para que la externalización de esta memoria colectiva se vuelva una consulta permanente de los que sí son parte de estos escenarios.

Ahora bien, una gran dificultad se seguiría teniendo si se llegase a contar con un espacio que compile todas las memorias de los eventos adelantados, pero que a pesar de eso no se pueda consultar, que no tenga un flujo que llegue a aquellos que busquen esa huella histórica de este ejercicio comunitario. Es por esto que la falta de una memoria colectiva se extiende no solo a la falta de esta sino al acceso que se le dé a esta al momento de tenerla.

Continuando con este reconocimiento de la falta en la dinámica de las memorias colectivas del evento, su compilación para dar cuenta de lo hecho, su acceso abierto para invitar a los interesados en el proceso, podemos apreciar también que es un elemento clave en este ejercicio comunicacional el escuchar e interactuar con ese otro consultante, con ese otro que busca la aproximación y que en ese ejercicio enriquece el proceso al habilitar el diálogo 
entre saberes. De esta manera se sale de ese reduccionismo en donde solo se generan producciones de índole informativo y se pasa a establecer puentes, a abrir puertas.

\section{La propuesta}

Entendiendo la situación inicial en la que se empieza este proceso de intervención, derivada de la aproximación diagnóstica, desde donde se reconocieron unas necesidades que devinieron en unas líneas de acción que proyectadas junto al objeto de desarrollo, buscan una transformación de las realidades y un empoderamiento de los actores del territorio, entendimos que hay mucho por hacer para aportar a lo colectivo, que no solo se necesitan de las voluntades, de un abanico de intervenciones sino que además se necesita de la continuidad de las mismas.

Es por eso que desde el confluir de las voces del territorio, de las madres comunitarias, de los líderes comunitarios y de los jóvenes líderes, se planteó un desarrollo escalar hacia esta meta desde nuestras propuestas de intervención y para esto se ha establecido, en la primera etapa de nuestro ejercicio, abordar los contenidos de lo trabajado por el Carnavalito en los años previos al desarrollo del presente documento, encontrando en ellos un respaldo y un impulso hacia lo proyectado, ya que estos son la evidencia de la continuidad de esfuerzos en esa búsqueda de transformación de los espacios de las intersubjetividades. Es demostrar que no se empieza de cero, que no hay un vacío detrás de esa búsqueda de inclusión activa de los habitantes periféricos al Carnavalito. Es reconocer el proceso adelantado por esos hacedores que impulsan las iniciativas de las nuevas voluntades y de las que con tradición se llevan.

Las líneas de acción se han orientado hacia temáticas particulares relacionadas con la implementación de espacios comunitarios para el intercambio de saberes, hacia el fomento y la promoción de tradiciones y nuevas presentaciones de ejercicios culturales, hacia la formación y capacitación de técnicas y procesos que enriquezcan las competencias de los actores territoriales y hacia aspectos relacionados con procesos de comunicación entendiéndolos como la dimensión fundamental para la intervención comunitaria.

Con estas líneas como orientación se estableció la propuesta del proyecto de Talleres de Memoria en Video, como la más accesible y adecuada herramienta para potencializar las actividades observadas en el territorio. Abordar la producción de sentidos y la resignificación de los mismos, teniendo como base la dimensión comunicacional, ayuda a reconocer los espacios de intercambio de intersubjetividades como la fuente y el núcleo de las transformaciones comunitarias. Los espacios de diálogo fomentan el planteamiento de discusión y negociación de temáticas relacionadas con la apropiación colectiva, el arraigo y la 
producción endógena de ejercicios comunitarios. Es en estos espacios donde se fomentan competencias que ayudan en la lectura e interpretación de discursos y producciones que hablan del territorio mismo. Se propone un ejercicio en donde el uso de un espacio para la práctica de herramientas de producción de contenidos audiovisuales ejerce como activador de procesos comunitarios, como el replantearse la posición propia dentro del entramado del territorio y reconocer sus potencialidades para la transformación.

Como punto de partida en los talleres, se ha trabajado para que se generen contenidos digitales de las iniciativas ya existentes por las colectividades del territorio mismo. En otras palabras, en los talleres se formarán inicialmente a jóvenes líderes en producción de contenidos audiovisuales, que expongan las actividades de todo lo que se realiza alrededor del Carnavalito, sus reuniones, sus manifestaciones, sus detalles, para poder difund irlos por canales digitales y así buscar que el impacto del ejercicio del Carnavalito se potencie y que a su vez apoye a futuras presentaciones del mismo; pero, la propuesta tiene como trasfondo real el fortalecimiento de la identidad comunitaria y la ciudadanía, esperand o que a futuro los participantes de los talleres puedan hacer uso tanto de los procesos técnicos de producción de contenidos audiovisuales como de las competencias de construcción comunitaria.

Los productos audiovisuales que de este proyecto se han derivado, han sido trabajados con los insumos dados por los registros del Carnavalito, tanto de exposiciones de años anteriores como de contenidos preproducidos que han reforzado la actividad de La fiesta popular. Estos contenidos han sido difundidos por canales digitales, esperando consolidarlos a estos como una ventana de acceso para la comunidad en general, aguardando establecer una comunicación bilateral entre habitantes y gestores del territorio.

El cúmulo de estos productos construirá el repositorio, a modo de videoteca digital, que será uno de los soportes de la memoria colectiva con la cual se espera fortalecer la deseada identidad comunitaria, construida ahora sobre la determinación y gestión de los habitantes del territorio.

Los participantes convocados para los talleres de Memoria en Video son jóvenes líderes de los barrios de las UPZ 69 y 70, de Ciudad Bolívar, que son parte de iniciativas colectivas, como las propuestas por la corporación Inti Tekoa, son jóvenes que han sido usuarios de los espacios de formación alternativa, que han participado de la producción del Carnavalito por la vida y el amor, algunos en la actualidad son líderes de iniciativas de transformación territorial como huertas comunitarias y colectivos para la equidad de género, además algunos han realizado sus pasantías profesionales en el territorio y continuado con su ejercicio social al culminar con sus compromisos académicos. Ellos son los que han participado de los 
espacios de discusión y han aportado sus saberes para construir una propuesta de cambio en la comunidad. Además, estos talleres han tenido, como uno de sus propósitos, la formación de futuros formadores, entendiendo que los que en el primer ciclo del proyecto han recibido la instrucción, en un futuro formen a nuevos integrantes de la comunidad.

\section{Justificación}

El beneficio de los talleres de Memoria en Video como proyecto, es que aborda de manera importante las líneas de acción, los fines esperados por el objetivo de desarrollo y las demandas encontradas a través de la aproximación documentada en este texto. Atendiendo a la población hacia la que queremos relacionar con la formación de formadores, unos integrantes jóvenes con unas buenas bases y competencias en manejo de equipos ofimáticos y una clara actividad en los ejercicios de servicio a la comunidad. En ellos encontramos el relevo y apoyo perfecto para los líderes que ya por muchos años han llevado la delantera en estos territorios. Con esto se verá en un futuro el trabajo mancomunado de la experiencia de los primeros líderes y los que llegan con sus nuevas contribuciones.

La difusión de las actividades y servicios de las instituciones sociales del territorio generarán, como beneficio, el uso y aprovechamiento para mejora en las competencias de los habitantes del sector; acarreará un empoderamiento y un arraigo por las actividades y por el territorio mismo. Estableciendo espacios de acción en donde se podrán sumar iniciativas nuevas o se fortalecerán las ya existentes, fomentando una perspectiva crítica frente a las dinámicas de la comunidad misma.

Entendiendo que muchas de las iniciativas planteadas en la comunidad carecen de difusión, encontramos que una gran cantidad de veces los esfuerzos de algunos gestores se pierden al no encontrar eco en la comunidad. Es, por tanto, que reconocemos que parte de los derivados del proyecto entrarán a construir elementos de la memoria de la comunidad, como lo es el repositorio audiovisual de las actividades de las instituciones territoriales.

Una fiesta sin memorias y registros puede pasar al olvido sin que se reconozca en ella sus potencialidades o aspectos a mejorar. La memoria es el referente histórico y educativo por medio del cual se registran y recuerdan acontecimientos, protagonistas y aprendizajes principales de una experiencia como la fiesta municipal. En este sentido, recomendamos hacer un registro completo de nuestras celebraciones tradicionales. (Zarama Vásquez, 2011, pág. 45). 
El apoyo principal de la Corporación INTI TEKOA además de las voluntades de algunos líderes comunitarios, abren el camino para el desarrollo de estas propuestas comunitarias.

El beneficio a corto plazo ha sido para los líderes iniciales que han recibido la instrucción de los talleres, ya que han sido formados con unas excelentes herramientas para uso en sus oficios personales, académicos y profesionales. A mediano plazo las instituciones que reciban el servicio de este grupo de líderes podrán exponer sus actividades a través de plataformas digitales con una buena calidad de producción. A largo plazo, lo que se espera, es que se cuente con un amplio repositorio de contenidos audiovisuales que den cuenta de todo lo que las instituciones comunitarias han desarrollado en el territorio.

La repercusión de la iniciativa de los talleres de Memoria en Video también tiene como propósito empoderar a los participantes de estos talleres dándoles las herramientas necesarias para que los contenidos que hablen de su territorio no sean generados por agentes externos a la comunidad, sino que estos contenidos sean generados por personas que viven y conocen el territorio. De esta manera los sentidos que se manejan por la comunidad podrán ser producidos por la misma comunidad y esta no es otra manera más que la forma de pluralizar las voces que hablan del territorio, es democratizar las opiniones, es irrumpir en las líneas unidireccionales de una comunicación impositiva en donde un lado producía contenidos acomodados a su propio beneficio y otro lado se sometía al impacto de lo producido, es por tanto reconocer la dimensión política de la intervención en el territorio y es darle actividad a esa voz y ese voto que tiene la comunidad para sí misma. El tomar parte en las decisiones sobre su propio territorio y el apropiarse del mismo han sido parte de esas herencias de las iniciativas adelantadas por décadas por instituciones como las madres comunitarias e INTI TEKOA en el propio territorio y que han creado una ruta a seguir en la búsqueda de llegar a esas metas de transformación positiva de la comunidad, gestionada por la misma comunidad. En esta producción endógena lo que se espera es que surja un sujeto crítico y partícipe, que salga de ese ensimismamiento y que se proyecte en relación con su comunidad.

El actuar sobre la comunidad es en sí mismo parte de ese propósito de transformación positiva, es cortar con la indiferencia de la inactividad, es mostrar a los demás habitantes de la comunidad que son unos agentes de cambio en potencia, es mostrar que la comunidad cuenta con una fuerza que se puede direccionar hacia su propio beneficio, es quitarle el monopolio de la opinión y la acción a los poderes hegemónicos que solo buscan la perpetuación del status quo. 


\section{Objetivo general}

Reconocer y dinamizar los procesos comunicacionales de la comunidad alrededor del Carnavalito, para fomentar la significación de las experiencias que posibiliten narrativas de una memoria cultural de la comunidad, a través de la implementación de técnicas y herramientas de comunicación audiovisual.

\section{Objetivos específicos}

Contribuir a la formación de la identidad comunitaria a través de procesos reflexivos de reconocimiento.

Formar a los líderes que participan de esta iniciativa en el uso de herramientas de registro y producción para generar contenidos que enriquezcan su memoria institucional.

Generar un autorreconocimiento en el proceso de sistematización de los eventos comunitarios con los líderes y participantes de estas iniciativas.

\section{Cronograma de actividades}

\section{Tabla 12}

CRONOGRAMA TALLERESFORMACIÓN

\begin{tabular}{|c|c|c|c|c|}
\hline Actividades & $\begin{array}{c}\text { Día, hora, } \\
\text { lugar. }\end{array}$ & Insumos & Responsable & $\begin{array}{c}\text { Resultados } \\
\text { esperados }\end{array}$ \\
\hline $\begin{array}{l}\text { Talleres } \\
\text { Formación } \\
\text { ciudadanía e } \\
\text { identidad } \\
\text { comunitaria. }\end{array}$ & $\begin{array}{l}\text { Del } 30 \text { de } \\
\text { noviembre al } 29 \\
\text { de febrero } \\
\text { Sede INTI } \\
\text { TEKOA } \\
\text { Horario } \\
\text { dependiendo a } \\
\text { la programación } \\
\text { de los } \\
\text { participantes }\end{array}$ & $\begin{array}{l}\text { Tablero, } \\
\text { marcador } \\
\text { borrable, } \\
\text { equipos de } \\
\text { cómputo, } \\
\text { paquete básico } \\
\text { de office para } \\
\text { Windows. }\end{array}$ & $\begin{array}{l}\text { Juan Carlos } \\
\text { Nieto }\end{array}$ & $\begin{array}{l}\text { Que los } \\
\text { participantes den } \\
\text { cuenta de los } \\
\text { procesos básicos de } \\
\text { su comunidad y las } \\
\text { implicaciones de } \\
\text { estas en la calidad } \\
\text { de vida de los } \\
\text { habitantes de su } \\
\text { territorio. }\end{array}$ \\
\hline
\end{tabular}




\begin{tabular}{|c|c|c|c|c|}
\hline $\begin{array}{l}\text { Talleres } \\
\text { formación en } \\
\text { producción } \\
\text { audiovisual }\end{array}$ & $\begin{array}{l}\text { Del } 30 \text { de } \\
\text { noviembre de } \\
2019 \text { al } 29 \text { de } \\
\text { febrero de } 2020 \\
\text { Sede INTI } \\
\text { TEKOA } \\
\text { Horario } \\
\text { dependiendo a } \\
\text { la programación } \\
\text { de los } \\
\text { participantes }\end{array}$ & $\begin{array}{l}\text { Equipos de } \\
\text { cómputo, } \\
\text { paquete básico } \\
\text { de office para } \\
\text { Windows, } \\
\text { celulares y } \\
\text { dispositivos de } \\
\text { grabación de } \\
\text { audio y video. }\end{array}$ & $\begin{array}{l}\text { Juan Carlos } \\
\text { Nieto }\end{array}$ & $\begin{array}{l}\text { Que los } \\
\text { participantes de los } \\
\text { espacios de } \\
\text { formación } \\
\text { obtengan las } \\
\text { herramientas } \\
\text { básicas de } \\
\text { producción en } \\
\text { piezas } \\
\text { audiovisuales. }\end{array}$ \\
\hline $\begin{array}{l}\text { Presentación } \\
\text { de piezas } \\
\text { audiovisuales } \\
\text { producidas } \\
\text { por los } \\
\text { participantes } \\
\text { de los } \\
\text { talleres. }\end{array}$ & $\begin{array}{l}\text { Dependiente del } \\
\text { producto a } \\
\text { exponer }\end{array}$ & $\begin{array}{l}\text { Videobeam, } \\
\text { computadora, } \\
\text { Tablero, } \\
\text { marcador } \\
\text { borrable. }\end{array}$ & $\begin{array}{l}\text { Participantes } \\
\text { del taller: } \\
\text { Memoria en } \\
\text { video }\end{array}$ & $\begin{array}{l}\text { Hacer una } \\
\text { exposición ante la } \\
\text { comunidad de los } \\
\text { productos } \\
\text { realizados e invitar } \\
\text { a nuevos líderes } \\
\text { para que hagan } \\
\text { parte de un nuevo } \\
\text { ciclo de formación. }\end{array}$ \\
\hline
\end{tabular}

\section{Presupuesto Recursos humanos}

\section{Tabla 13}

DESCRIPCIÓN PRESUPUESTO RECURSO HUMANO

\begin{tabular}{|c|c|c|}
\hline Descripción & Precio por unidad & Precio total \\
\hline Gestor comunitario & $\$ 0$ & $\$ 0$ \\
\hline Productor audiovisual & $\$ 0$ & $\$ 0$ \\
\hline Diseñad or gráfico & $\$ 0$ & $\$ 0$ \\
\hline Reportero & $\$ 0$ & $\$ 0$ \\
\hline Animador gráfico & $\$ 0$ & $\$ 0$ \\
\hline Total & $\$ 0$ & $\$ 0$ \\
\hline
\end{tabular}

\section{Presupuesto Recursos Materiales}

Tabla 14

DESCRIPCIÓN PRESUPUESTO RECURSO MATERIAL

\begin{tabular}{lcc}
\multicolumn{1}{c}{ Descripción } & Precio por unidad & Precio total \\
\hline Computadoras con paquete básico de office & $\$ 0$ & $\$ 0$ \\
\hline Celulares con cámara de video y fotografía & $\$ 0$ & $\$ 0$ \\
\hline Cables de datos & $\$ 0$ & $\$ 0$ \\
\hline
\end{tabular}




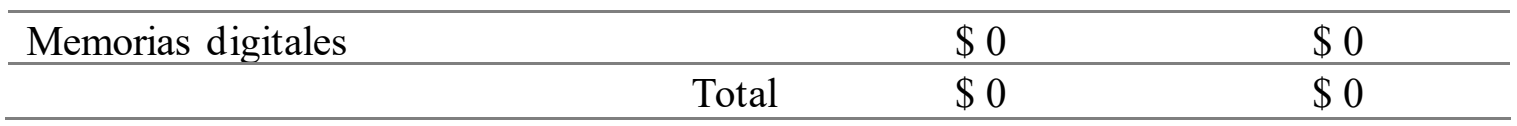

\section{Presupuesto Viáticos}

Tabla 15

DESCRIPCIÓN PRESUPUESTO VIATICOS

\begin{tabular}{lcc}
\hline \multicolumn{1}{c}{ Descripción } & Precio por unidad & Precio total \\
\hline $\begin{array}{l}\text { Viajes en colectivo para realizar las sesiones } \\
\text { del Taller memoria en video. }\end{array}$ & Por definir & Por definir \\
\hline Viajes en colectivo para realizar entrevistas. & Por definir & Por definir \\
\hline $\begin{array}{l}\text { Viajes en colectivo para hacer registros de } \\
\text { eventos comunitarios. }\end{array}$ & Por definir & Por definir \\
\hline $\begin{array}{l}\text { Viajes en colectivo para asistir a reuniones } \\
\text { de la comunidad. }\end{array}$ & Por definir & Por definir \\
\hline & & Potal \\
\hline
\end{tabular}

\section{Presupuesto total}

Tabla 16

DESCRIPCIÓN PRESUPUESTO TOTAL

\begin{tabular}{lc}
\multicolumn{1}{c}{ Descripción } & $\$$ \\
\hline Recursos humanos & $\$ 0$ \\
\hline Recursos materiales & $\$ 0$ \\
\hline Viáticos & Por definir \\
\hline \multicolumn{1}{c}{ Total } & Por definir \\
\hline
\end{tabular}

\section{Calendario de erogaciones}

Tabla 17

DESCRIPCIÓN CALENDARIO EROGACIONES

\begin{tabular}{lcccc}
\multicolumn{1}{c}{ Descripción } & Mes 1 & Mes 2 & Mes 3 & Total \\
\hline Recursos humanos & $\$ 0$ & $\$ 0$ & $\$ 0$ & $\$ 0$ \\
\hline Recursos materiales & $\$ 0$ & $\$ 0$ & $\$ 0$ & $\$ 0$ \\
\hline Viáticos & Por definir & Por definir & Por definir & Por definir \\
\hline \multicolumn{1}{c}{ Total } & Por definir & Por definir & Por definir & Por definir \\
\hline
\end{tabular}




\section{Impacto social alcanzado}

Se debe aclarar que al hablar de impacto social hacemos uso de este término en dos líneas de intervención, la primera corresponde a la que se da en el grupo de trabajo de los talleres, con los jóvenes líderes en los diálogos y la formación, y a las instituciones que son representadas en los contenidos realizados. La segunda se relaciona con el uso de los contenidos producidos en los talleres y que se extienden abiertamente a la comunidad.

Para la primera, podemos decir que han sido 13 los talleristas que han hecho parte de los espacios de diálogo y formación y que, a su vez, con los contenidos que se han generado han favorecido a más de 120 profesionales del territorio, entre los que se encuentran integrantes de la Corporación Inti Tekoa y Madres comunitarias.

Para la segunda, inicialmente se esperaba que lo trabajado desde los talleres de Memoria en Video llegase, en primera instancia, a más de 900 personas, entre las madres comunitarias, los niños de sus jardines y los familiares de los niños, además de los integrantes de las instituciones sociales alrededor de eventos como el propio Carnavalito; por fortuna, constancia y voluntad se ha superado ese número y ha llegado a más de 1400 impactos directos, registrados en redes sociales de uso institucional (evidencias en el apéndice).

\section{Impacto social indirecto}

Lo que se ha esperado, desde la concepción de los talleres, es que los derivados de estas intervenciones sirvan de instrumento comunicacional con la propia comunidad, que muchas veces observa las actividades que acontecen en su territorio, pero no tiene idea de qué está ocurriendo. No les encuentra sentido a las actividades pues no está al tanto de su causa o propósito y le atribuye elementos que nada tiene que ver con la realidad del evento. Es justamente para aclarar esas incógnitas que se ha buscado producir y usar contenidos en redes sociales digitales de uso abierto, extendiendo puentes que generen un diálogo entre las instituciones territoriales y la propia comunidad. Esto incluye a las entidades de orden político, ONG's, instituciones de trabajo social y otras comunidades que busquen guías para replicar las actividades que en este territorio se realicen.

\section{La ejecución del proyecto}

"Gestionar es poner el proyecto en acción" (Ceraso, et al, 2007, pág. 131). "Gestionar es comunicarnos" (Ceraso, et al, 2007, 


\section{Selección de participantes}

La idea a mediano y largo plazo es que estos talleres de Formación en ciudadanía e identidad comunitaria y Formación en producción audiovisual, se repliquen con nuevos integrantes, y que de estos los que en un momento fueron formados se vuelvan formadores comunitarios.

El ejercicio que ha sido desarrollado, inició con el grupo que fue convocado por uno de los líderes comunitarios, Fernando Cardona, líder fundad or de Inti Tekoa. Este llamado recepcionó a un grupo de jóvenes de la zona, que han sido parte de otros programas que se han realizado en el territorio y de los cuales algunos ya son los líderes actuales de los procesos; jóvenes líderes y lideresas que se proyectan como futuros guías de la comunidad. Algunos ya cuentan con títulos profesionales o están en el tránsito hacia estos. Ellos cuentan con conocimientos básicos en el manejo de aparatos de cómputo y sus software de uso más conocidos. Tras convocarlos y darles la orientación inicial, se empezó con los espacios de intercambios formativos. Para esto se dispuso de tiempos a común acuerdo con los integrantes del grupo.

Se aprovecharon positivamente las instalaciones de la Corporación Inti Tekoa, dando tiempo para varios encuentros formativos, en donde los que tomaban la instrucción en algunos programas ofimáticos aportaban desde sus saberes al constructo que se estaba buscando que fuera parte de la primera entrega de contenidos de los repositorios de las memorias de la comunidad.

Para estas entregas se establecieron tiempos de avance y se asignaron roles y responsabilidades para la producción. Siendo lo clave en este ejercicio la formación y la aprehensión de los integrantes y no los productos emergentes de estos espacios, pues, de esta manera se daba lugar al propósito de estos ejercicios, que es el que estos talleres se sigan replicando, pero desde la guía de estos futuros líderes del territorio, quienes han de dar cuenta de unas competencias de transformación social/comunitaria.

La atención dada a los diálogos de los actores del espacio de intercambio, en cada sesión, ayudó a acercarse más a esas nociones que tienen los integrantes de los talleres acerca de su territorio, sus posturas, sus proyecciones y de cuáles son las expectativas para este.

\section{Actividades realizadas}

"El medio ciudadano le abre un espacio comunicativo al individuo; es decir, le ofrece la posibilidad para que comience a manipular lenguajes, signos, códigos, y poco a poco aprenda a nombrar el mundo en sus propios términos.” (Rodriguez, 2013, pág. 100). 
Desde la sesión inicial se trabajó con los integrantes de manera activa y de ellos se estimó cuál era el nivel de desarrollo de conocimiento en el manejo de las herramientas de cómputo y los software del paquete básico de office con los que contaba la sede de la Corporación Inti Tekoa. Después de esto se desarrollaron ejercicios en donde los que presentaban mayor dominio de las herramientas orientaban a los que tenían menor dominio. Una vez aproximados a un nivel inicial se trabajó como idea general lo que comprendían las producciones audiovisuales que se esperaban desarrollar en los talleres. En los avances de cada sesión se fueron sumando los resultados alcanzados en sesiones previas y de esta manera fuimos dando cuenta del proceso. Como punto central de nuestro interés en esta intervención, junto a la formación operativa de producción de contenidos, se trabajó acerca del trasfondo territorial de esta actividad, donde se realizaron diálogos en los que circulaban saberes en relación a la comunidad, sus identidades, sus proyecciones y la construcción de sus memorias.

Con la excusa de una conversación suelta se planteaban problemáticas presentes en el territorio y se encausaban las discusiones hacia la búsqueda de movilización de los sentidos y hacia su transformación misma. (Ver anexo Programa Talleres Memoria en video).

\section{Productos entregables}

Debemos recordar que el fin último de este proyecto de los talleres de Memoria en Video es promulgar las cualidades que activan la movilización popular hacia la transformación. Entendemos entonces que estas tareas no tienen un estandarte último para establecer el logro puntual de su meta y por tal razón damos por entendido que esta es una tarea continua y fuera de registros temporales. Como producto final tomamos entonces a aquellos contenidos desarrollados por el grupo de talleristas en los espacios de los talleres.

Estos productos han sido parte de presentaciones institucionales y forman parte del nuevo repositorio de contenidos digitales que reforzarán la memoria colectiva de la comunidad. Para dar cuenta de estos avances se presentaron unos cortos audiovisuales desarrollados con contenidos del territorio y producción de los integrantes de los talleres. 


\section{CAPITULO 4}

\section{Mi proceso. Unas comillas aparte.}

Es una paradoja que nos encontremos en las conclusiones de un trabajo que es recién el inicio de un camino. El proceso llevado hasta acá da cuenta de varios años de aproximaciones que han aportado a las semillas que ya se ven en la comunidad y que en su crecimiento también me han cambiado a mí mismo como investigador. El enriquecimiento personal ha sido incontable, el discurso y los conceptos con los que llegué al iniciar este viaje personal han sido nutridos por la realidad transformadora de una comunidad con muchas potencialidades.

Para plantearme en el cierre de este proceso es preciso entender el contexto en el que se concluye este documento, el año 2020, que ha tenido como protagonista a la pandemia establecida por la propagación del virus del covid-19, y esto ha acarreado un reto para la humanidad. El aislamiento personal en el mundo ha replanteado las dinámicas de socialización, y el territorio latinoamericano no ha sido ajeno a esta realidad. La exposición de la vulnerabilidad de poblaciones naturalmente olvidadas por el Estado, remarca lo denunciado por las instituciones que buscan escenarios equitativos y además lo marcado en el trabajo de territorio descrito en este documento. La localidad de Ciudad Bolívar, al contar con una población en alto grado de vulnerabilidad ha expuesto, aún más, la marginalidad impuesta por las colectividades hegemónicas que procuran el statu quo, y ha sufrido los embates consecuencia de esta pandemia. Los efectos de esta situación han hecho presencia en la naturaleza de la presentación del Carnavalito por la vida y el amor, ya que para el año 2020 no se pudo hacer en presencialidad en las calles y por tanto se ha replanteado, y así ha tenido este año su primera presentación en formato digital, dando un nuevo escenario para portar al tejido comunitario. Situación que me ha puesto ante una realidad que necesita propuestas para enriquecer el territorio y que ha logrado que en mi crecimiento personal pueda definirme como un gestor que aporta al entramado y a las dinámicas de los saberes que circulan en la realidad.

Mi aporte en los escenarios de los talleres y lo hecho en estos espacios para la construcción de territorio ya no es parte de un producto a entregar, sino que ahora es parte de las destrezas y la historia de los actores que han participado de lo acá hecho y del territorio en el que ellos se encuentran inmersos. Dándome esto último nuevos sentidos al significado de intervención comunitaria y su relación con las manifestaciones populares, pues el Carnavalito 
es un ejemplo de todas esas iniciativas que surgen en las comunidades que procuran mejorar sus condiciones de vida desde su propia gestión y sus saberes, a través de presentaciones de fiestas populares, que a pesar de las dificultades de esas realidades en las que se encuentran inmersas logran festejar la vida, esto se ve en muchos barrios, en muchas comunidades tanto rurales como urbanas y todas ellas son una grata exposición del alma de las sociedades.

\section{CONCLUSIONES}

Empezar a establecer conclusiones de un trabajo que continúa es complejo, aún sabiendo que al momento de lectura de este documento se siguen dando aportes fruto de los talleres y de las iniciativas particulares de los integrantes de estos. Pero, se presentan estas a modo de evaluación del proceso recorrido y para fines de esta tesis. Es por tanto entendible que para la redacción del epílogo de este documento se han tomado en cuenta observaciones particulares de los aspectos a resaltar de la experiencia recorrida y cuestiones propias del presente texto, buscando que de esta manera se pueda continuar con lo acá avanzado o que se abran nuevas propuestas para la intervención transformadora de la comunidad, tomando lo acá escrito como un enganche para futuras posibilidades. Algunas preguntas residuales que surgen a partir del ejercicio acá documentado, y que podrían ser parte de futuros procesos en el territorio, son: ¿Puede este ejercicio de construcción de memoria colectiva, a través de la producción y difusión de contenidos audiovisuales, devenir en una emisora comunitaria?, ¿Con qué instancias comunitarias se podría articular esta iniciativa para aportar al desarrollo del territorio?, ¿Cómo se garantizaría la continuación de la construcción del repositorio de memoria colectiva?

\section{Respondiendo la pregunta}

Un buen ejercicio para la conclusión de esta tesis es darle cierre a los elementos abordados en el documento y para esto es posible trabajar en primer lugar respondiendo a la pregunta inicial. Aunque esta se ha respondido a través del texto siempre es mejor dejar las ideas claras y para esto se presentarán a continuación una serie de etapas en donde vemos cómo hemos respondido a la cuestión. 


\section{Figura 10}

\section{PREGUNTA FRAGMENTADA}

¿Se puede desde una estrategia comunicacional fomentar la significación del Carnavalito, por medio de las dinámicas de los gestores e integrantes de la comunidad, tales como espacios de formación e inclusión, para la creación de una memoria audiovisual que contribuya a la formación de procesos comunitarios, como el fomento de la integración y la identidad del territorio?

A manera de mejorar el entendimiento de las etapas en las que hemos dado respuesta a la pregunta y de reconocer las partes de esta, ésta se ha fragmentado con colores distintivos, para que sea más fácil la ubicación de las correspondencias de los colores de la pregunta con los colores de las figuras presentadas en esta sección.

En la primera etapa y gracias a la aproximación y los datos hallados en el diagnóstico comunicacional, encontramos que lo que reconocen los participantes de las actividades comunitarias es que el propósito de sus dinámicas es dar una contribución a la formación y fomento de procesos comunitarios. Y que con la fuerza de estas dinámicas es que se mantienen estos procesos.

\section{Figura 11}

\section{ETAPA 1. RESPUESTA A LA PREGUNTA}

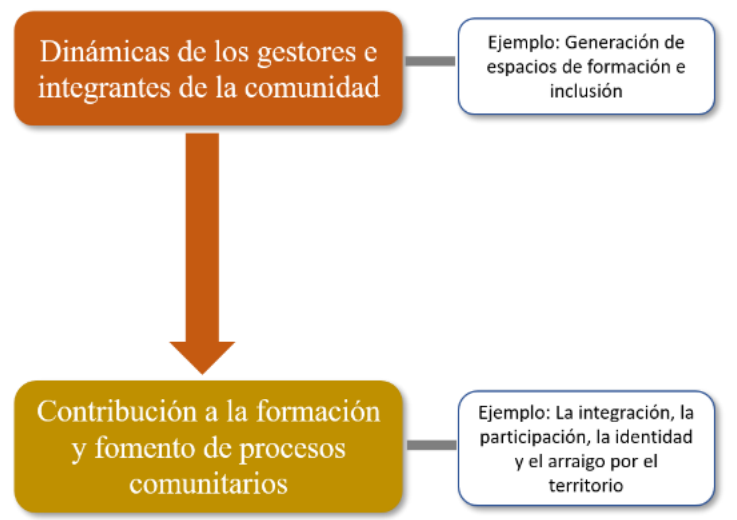

Pero al reconocer en esta dinámica aspectos como el gran esfuerzo y el posterior desgaste por la exigencia misma de sostener estos procesos, notamos que una gran fuente de ayuda para estas dinámicas es la propuesta de la inclusión de un repositorio de memoria que con su contenido y función sume a la fuerza de los gestores, quienes con cada acción generan material que fortalezca la memoria. 


\section{Figura 12}

\section{ETAPA 2. RESPUESTA A LA PREGUNTA}

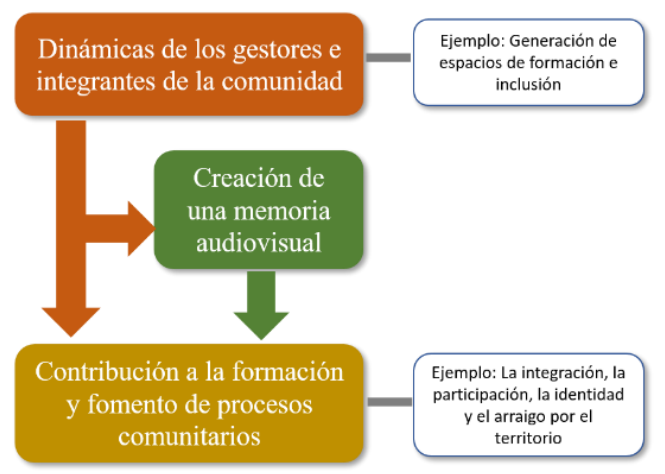

Entendido lo anterior, vemos que de esta manera es más claro ubicar el lugar dinámico de la estrategia comunicacional, ya que esta no tiene un lugar puntual, sino que atraviesa toda esta interrelación en cada uno de los lugares. Está presente reconociendo las dinámicas de los gestores al consultarlos y participar de sus gestiones, está en los procesos al evaluarlos, definirlos y compartirlos y el lugar más claro donde podemos ubicarla es en la memoria ya que esta en sí misma es una acción de una estrategia comunicacional.

\section{Figura 13}

\section{ETAPA 3. RESPUESTA A LA PREGUNTA}

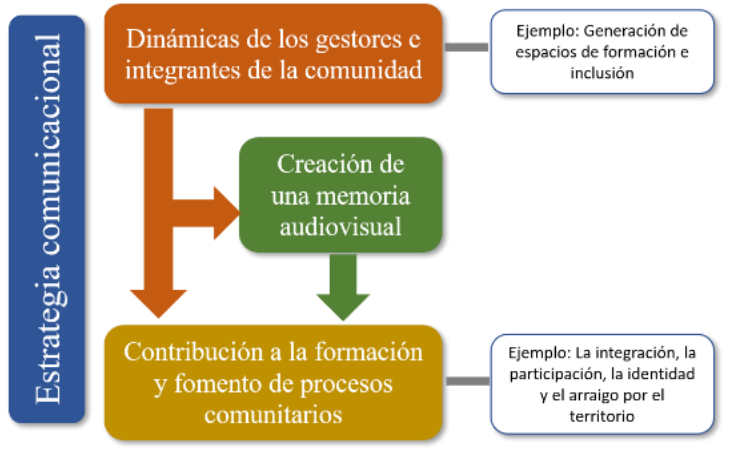

Ya en este momento es cuando vamos reconociendo el lugar de cada fragmento de la pregunta en su ubicación representacional, solo quedand o pendiente el lugar del fomento de la significación del Carnavalito y este es siend o parte del tema a manejar dentro de las memorias. Es clave entender esta relación del tema a manejar, pues, aunque nuestro interés en la actualidad sea el Carnavalito, puede que en un futuro y bajo otras circunstancias la comunidad quiera trabajar, reconocer y fomentar la significación de otro proceso; sería entonces cuando se podría hacer uso de lo que hemos trabajado en el ejercicio de esta tesis, reemplazando al Carnavalito por el nuevo proceso de interés. 
Ahora bien, ¿qué entendemos por tema a manejar? Entendemos que los contenidos de esa memoria están relacionados con el Carnavalito, por ejemplo. Si el tema a manejar son los talleres de robótica, dictados en la Corporación Inti Tekoa, entonces las memorias estarán relacionadas con estos talleres. El propósito para un futuro es que haya un repositorio de memoria general que contenga material de muchos procesos, pero por garantía inicial en nuestra tarea es mejor reconocer las particularidades de cada proceso en su singularidad.

\section{Figura 14}

\section{ETAPA 4. RESPUESTA A LA PREGUNTA}

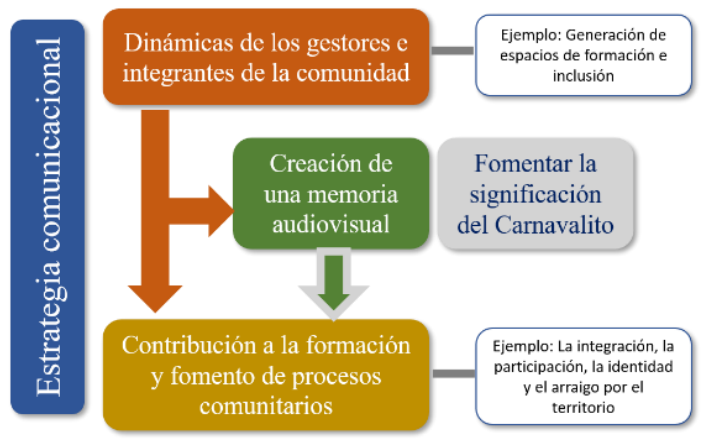

Vemos que al incluir el fragmento de "fomentar la significación del carnavalito", éste matiza el aporte de la memoria a los procesos comunitarios, cerrando toda la interrelación acá reconocida.

Entonces a modo de respuesta a la pregunta, entend emos que la estrategia comunicacional sí fomenta la significación del Carnavalito a través de las dinámicas de los gestores e integrantes de la comunidad, que crean memorias (en este caso audiovisuales, aunque podrían ser de otra índole) y de esta forma contribuyen a la formación y el fomento de los procesos comunitarios.

\section{General}

Encontrarse con personas reales en el espacio donde los medios de comunicación muestran cifras y noticias que rayan con el amarillismo, es parte de esa responsabilidad que debemos tener todos si deseamos tener un mundo mejor. Abrir las puertas de espacios que han sido llevados al silencio y mostrar que también hay quienes trabajan para mejorar las condiciones de una comunidad, nos ayuda a romper con ese currículum oculto de las sociedades modernas que nos dicta qué debemos pensar en que lo que prima es el bienestar propio por encima del de los demás. Al estar al lado de las personas alrededor del Carnavalito se entiende que la construcción de la sociedad no se da en opiniones aisladas e impermeables 
a la mirada del otro, sino en la conjunción y la puesta en cuestión de todas estas miradas, para encontrar consensos, los encuentros que construyen comunidad, sabiendo que de esta se desprenderán las condiciones para una mejoría en la calidad de vida, en una mejor humanidad.

Los habitantes del sector, madres comunitarias, voluntarios, profesionales y demás participantes de esta construcción que hemos observado en esta tesis, son los gestores que esparcen las semillas de la voluntad, que buscan que los habitantes del territorio sobrelleven esa realidad del alto volumen de población desplazada que llega a la zona, de los indicadores de vulnerabilidad, de inseguridad, de desempleo, de aband ono del Estado, y que busquen caminos alternativos que contribuyan a la construcción positiva de su entorno. Además, hemos encontrado gratamente que parte de las tareas realizadas en el territorio son las que han sido planteadas para que no solo se busque caminos, sino que a su vez se construyan estos, dando así un espacio para acabar con la pasividad de los miembros comunitarios, ayudando a que muchos rompan ese cascarón de la individualidad, de esa entropía tan dañina para la construcción de cualquier sociedad sana.

Una de las repercusiones que podemos encontrar de las iniciativas acá tratadas es que en la significación que tengan los sujetos del territorio ya no se estime como utópico el escenario de mejoría de sus realidades, sino que se reconozca un tangible camino por el que se pueda transitar para construir nuevas condiciones para la comunidad, que muchas veces es empujada a la apatía y que terminan reforzando eso contra lo que se está luchando. Es por eso que marcamos como positivo lo que hemos encontrado en este trabajo, y es el reconocer el momento actual, las líneas de acción para trabajo a futuro y la fuerza del aporte de la memoria en la comunidad.

Estamos al tanto que esta intervención no va a cambiar la totalidad de las condiciones encontradas en el territorio, pero si podemos ver que aclaran parte del panorama en el que se trabaja y por tanto sabemos que se suma a las labores realizadas, esperando seguir fortaleciendo ese espacio al que se quiere llevar a los habitantes de esta comunidad de los barrios del sur de Bogotá, donde se realiza el Carnavalito.

Si bien sabemos que para llevar a cabo nuestros deseos los esfuerzos deben ser enormes, lo que también sabemos es que detenernos pasivamente a observar lo que pasa en el mundo solo generará más desigualdad e iniquidad y un inevitable colapso que acabe con esas buenas obras que nos alivian la vida. 


\section{Replicabilidad}

Una de las gratas reflexiones que ha traído la edición de este documento y el recuento del camino recorrido, es que podemos ver que este ejercicio puede llegar a ser repetido en otras comunidades que tengan como propósito replicar estas dinámicas en sus territorios. Obviando la adaptación a las particularidades de sus comunidades, vemos que las bondades de las estrategias comunicacionales tienen en su naturaleza propia la contribución comunitaria.

En los vastos territorios latinoamericanos encontramos, para desgracia humana, que hay muchas comunidades vulnerables expuestas al aband ono estatal y el abandono propio. Consideramos que estas podrían ver para sí mismas una contribución positiva el realizar actividades acá descritas, no solamente como actividad movilizadora sino con el propósito de entretejer las intersubjetividades que tantas veces han sido llevadas a la invisibilidad con los embates sociales, políticos y económicos. No es este un ejercicio recreativo sino un proceso para ejercer la ciudadanía, para salir de esa entropía que aísla. Es entonces cuando vemos que esto es un propósito de largo aliento, pero de nutritivos frutos. Esto es construcción humana, esto es tejido social. Y bien servidos nos sentiríamos al saber que podemos aportar poniendo una semilla de estos nuevos campos de crecimiento. 


\section{Referencias}

Agencia EFE. (26 de Mayo de 2019). America Sociedad. Obtenido de efe.com: https://www.efe.com/efe/america/sociedad/radiografia-de-los-falsos-positivos-encolombia/20000013-3985521

Barbosa, C. V. (1 de Octubre de 2019). Economía. Obtenido de elespectador.com: https://www.elespectador.com/economia/por-que-esta-subiendo-el-desempleo-encolombia-articulo-883869

Bertalanffy, L. V. (1989). Teoria General de los sistemas. Mexico: Fondo de cultura económica.

Blanco Abarca, A., \& Rodríguez Marín, J. (. (2007). Intervención Psicosocial. Madrid: Pearson Educación, S.A.

Boyle, J. (2003). Estilos de etnografía. En J. Morse, Asuntos críticos en los métodos de investigación cualitativa (págs. 185-214). Medellin: Universidad de Antioquia.

Bustos, E. O. (2013). Panfletos amenzan con 'limpieza social' en Piedecuesta. Obtenido de Vanguardia: https://www.vanguardia.com/santander/area-metropolitana/216854panfletos-amenzan-con-limpieza-social-en-piedecuesta

Cardona, F. (2016). Carnavalito Por La Vida Y El Amor, Una Experiencia De Construcción Comunitaria. Barrio Jerusalén, Ciudad Bolívar. Bogotá D.C.: Universidad Pedagógica Nacional. .

Ceraso, C. (2008). Redes de Desarrollo Local y Colectivos de Comunicación en el Territorio. La Plata: Universidad Nacional de la Plata.

Ceraso, C., Arrúa, V., \& Retola, G. (2007). Sembrando mi tierra de futuro. La Plata: Universidad Nacional de La Plata.

Comisión filmica de Bogotá. (s.f.). Barrio Sierra Morena. Obtenido de www.filmingbogota.gov.co: https:/www.filmingbogota.gov.co/?q=es/content

Craig, G., \& Mayo, M. ((2004/1995)). Community Empowerment. London: Zed Books.

DANE. (2015). CENSO 2015/Censo Básico. Obtenido de DANE: http://systema59.dane.gov.co/cgibin/RpWebEngine.exe/PortalAction?\&MODE=MAI $\mathrm{N} \& \mathrm{BASE}=\mathrm{CG} 2005 \mathrm{BASICO \& MAIN}=$ WebServerMain.inl

Erikson, E. (1959). Identity and the life cycle. New York: W. W. Norton \& Company. Fals Borda, O. (1959). Accion comunal en una vereda colombiana. Santa Fe de Bogotá: Universidad Nacional. Monografias Sociológicas.

Flórez, F. (2019). Estrategia de procesos comunicacionales, para transformar las situaciones problemáticas de vida, de la Comunidad LGBT. Medellín: UNLP. 
Gallo, I. (13 de Noviembre de 2017). Las 2 orillas. Obtenid o de Las 2 orillas: https://www.las2orillas.co/el-desesperado-alcalde-de-armero-nadie-escucho/

Gluck, M. A. (2009). Aprendizaje y memoria, Del cerebro al comportamiento. México: McGraw Hill.

Grau Rebollo, J. (2002). Antropología audiovisual. Fundamentos teóricos y metodológicos en la inserción audiovisual en diseños de investigación social. Barcelona: Bellaterra.

Guarnizo, J. (15 de Agosto de 2015). Nación. Obtenido de Semana.com: https://www.semana.com/nacion/articulo/la-foto-que-dejo-al-descubierto-losdesmanes-de-la-operacion-orion/438656-3

Guber, R. (2001). La etnografía. Bogotá: Norma.

Herrera Flores, J. (2005). El proceso cultural: Materiales para la creatividad humana. Sevilla: Aconcagua.

Herrera Flores, J. (2008). La reinvención de los derechos humanos. Sevilla: Atrapasueños. Herrera, F. A. (2016). Porque ese es el lema de nosotros. (J. C. Nieto, Entrevistador) Hombrados Mendieta, M. I. (2013). Manual de psicología comunitaria. Madrid: Editorial Síntesis, S. A.

Inti Tekoa. (2018). Agenda Carnavalito Intitekoa. Agenda Carnavalito 2018. Bogotá. Isaza, J. (2008). Conurbación Y Desarrollo Sustentable: Una Estrategia De Intervención Para La Integración Regional. Bogotá D.C.: Pontificia Universidad Javeriana. Kaplún, M. (1998). Una pedagogía de la comunicación. Madrid: Ediciones de la Torre. León, O. (2013). Democratizar la palabra. Movimientos convergentes en comunicación. Quito: Alai.

Marcia, J. E. (1980). Identity in Adolescence. En J. A. (Ed.), Handbook of Adolescent Psychology. New York: Wiley.

Marín, N. (5 de Noviembre de 2017). Justicia. Obtenido de elespectador.com: https://www.elespectador.com/colombia2020/justicia/verdad/desaparecidos-delpalacio-de-justicia-una-busqueda-de-varias-generaciones-articulo-855986

Martín Serrano, M. (1995). Las transformaciones sociales vinculadas a la era audiovisual. En B. Diaz Nosty, Comunicación social. Tendencias. Informes anuales de Fundesco. Las nuevas fronteras de los medios (págs. 217 - 225). Madrid: Fundesco.

Martín-Barbero, J. (1991). De los medios a las mediaciones. Barcelona: Gustavo Gili S.A.

Massoni, S. (1 de Febrero de 2017). La comunicación como encuentro sociocultural que enactúa. (C. León, Entrevistador)

McLuhan, M., \& Powers, B. (1995). La aldea Global. Barcelona: Gedisa S.A. 
Montenegro, M. (2004). Introducción a la Psicología Comunitaria. Barcelona: Editorial UCO.

Montero, M. (2004). Introducción a la psicología comunitaria. Buenos Aires: Paidós.

Montero, M. (2006). Hacer para transformar. Buenos Aires: Paidos.

Naciones Unidas. (Octubre de 2020). Derechos Humanos. Obtenid o de Naciones Unidas: https://www.un.org/es/sections/issues-depth/human-rights/index.html

Neira, A. (13 de Mayo de 2002). Nación. Obtenido de Semana.com: https://www.semana.com/nacion/articulo/como-fue-la-tragedia-de-bojaya/50635-3

Noticias Uno. (19 de Octubre de 2019). Noticias Uno. Obtenido de canall.com.co: https://noticias.canall.com.co/noticias/un-juez-amenazo-a-una-victima-con-enviarlaante-la-fiscalia-por-reclamar-sus-derechos/

Noticias Uno. (17 de Noviembre de 2019). Noticias Uno. Obtenido de canall.com.co:

https://noticias.canall.com.co/noticias/juez-que-amenazo-a-victimas-con-tirarlas-a-lafiscalia-reprobo-examen-de-conocimientos-y-aptitudes/

Otalora, Y. V. (2014). Transformación De Las Familias Campesinas En El Proceso De Metropolización De La Ciudad Bogotá. Bogotá.: Universidad Nacional De Colombia.

Pulzo. (5 de Octubre de 2019). Economía. Obtenido de pulzo.com:

https://www.pulzo.com/economia/vicepresidenta-marta-lucia-ramirez-dice-aumento

Pulzo. (29 de Abril de 2019). Nación. Obtenido de pulso.com:

https://www.pulzo.com/nacion/piden-investigar-luis-carlos-sarmiento-presid ente

Restrepo, E. (2016). Etnografia: Alcances, técnicas y éticas. Bogotá: Envión.

Restrepo, L. a. (Dirección). (2003). La primera noche [Película].

Revista Dinero. (3 de Julio de 2017). Economía. Obtenido de dinero.com:

https://www.dinero.com/economia/articulo/empobrecimiento-de-los-campesinoscolombianos-por-importaciones/242668

Revista Semana. (18 de Enero de 2017). Judicial. Obtenid o de semana.com:

https://www.semana.com/nacion/articulo/caso-grafitero-condenan-a-37-anos-decarcel-al-policia-que-le-disparo-a-diego-felipe-bec erra/512503

Rodriguez, C. (2013). Comunicación ciudadana en Montes de María - Colombia. Revista Luciérnaga, Año 5, Edición 9, 99-115.

Rojas Gomez, M. (2011). Identidad Cultural e integración. Desde la ilustración hasta el romanticismo latinoamericanos. . Bogotá D.C.: Bonaventuriana.

Rowlands, J. (1997). Questioning Empowerment Working with Women in Honduras. Oxford: Oxfam. 
Ruiz-Vargas, J. M. (1991). Manual de psicología de la memoria. Madrid: Editorial Síntesis, S. A. .

Santander, P. (2011). Por qué y cómo hacer Análisis de Discurso. Cinta moebio $N^{\circ} 41,207$ 224. Recuperado el 28 de enero de 2017 de www.moebio.uchile.cl/41/santander.html. Obtenido de Santander, P. (2011). Por qué y cómo hacer Análisis de Discurso. Cinta moebio 41: 207-224. Recuperado el 28 de enero de 2017 de www.moebio.uchile.cl/41/santander.html

Secretaría de Salud de Bogotá. (2017). Análisis de condiciones, calidad de vida, salud y enfermedad. Localidad Ciudad Bolívar. Obtenido de Secretaría de Salud de Bogotá: http://www.saludcapital.gov.co/DSP/Diagnsticos\%20distritales\%20y\%20locales/Loca 1/2017/Subred\%20Sur/CIUDAD

Secretaría Distrital de Planeación. (2013). Última actualización de estratificación en Bogotá asignó estrato a más de 35 mil viviendas nuevas. Obtenido de Secretaria Distrital de Planeación: http://www.sdp.gov.co/sites/default/files/060__actuailzacionestratificacionbogota.pdf

Secretaría Distrital de Planeación. (2019). Estratificación socioeconómica/Estratificación por localidad. Obtenido de Secretaría Distrital de Planeación:

http://www.sdp.gov.co/gestion-estudios-estrategicos/estratificacion/estratificacion

Smith, A. (1997). La identidad Nacional. Madrid: Trama.

Telesur . (7 de Noviembre de 2019). America Latina. Obtenido de telesurtv.com: https://www.telesurtv.net/news/indigenas-asesinados-colombia-gobierno-duque20191106-0043.html

Venier, E. (2014). Entramado organizacional y practicas comunicacionales en redes para la sustentabilidad territorial del Gran Chaco Americano. La Plata: Universidad Nacional de La Plata.

Viloria, C. (2020). (J. C. Nieto, Entrevistador)

Watzlawick, P. (1997). La teoría de la comunicación humana. Barcelona: Herder.

Zarama Vásquez, E. G. (2011). Fiestas populares en clave de paz y convivencia. Guía para la aplicación. Bogotá: Deutsche Gesellschaft für Internationale Zusammenarbeit (GIZ) GmbH. 

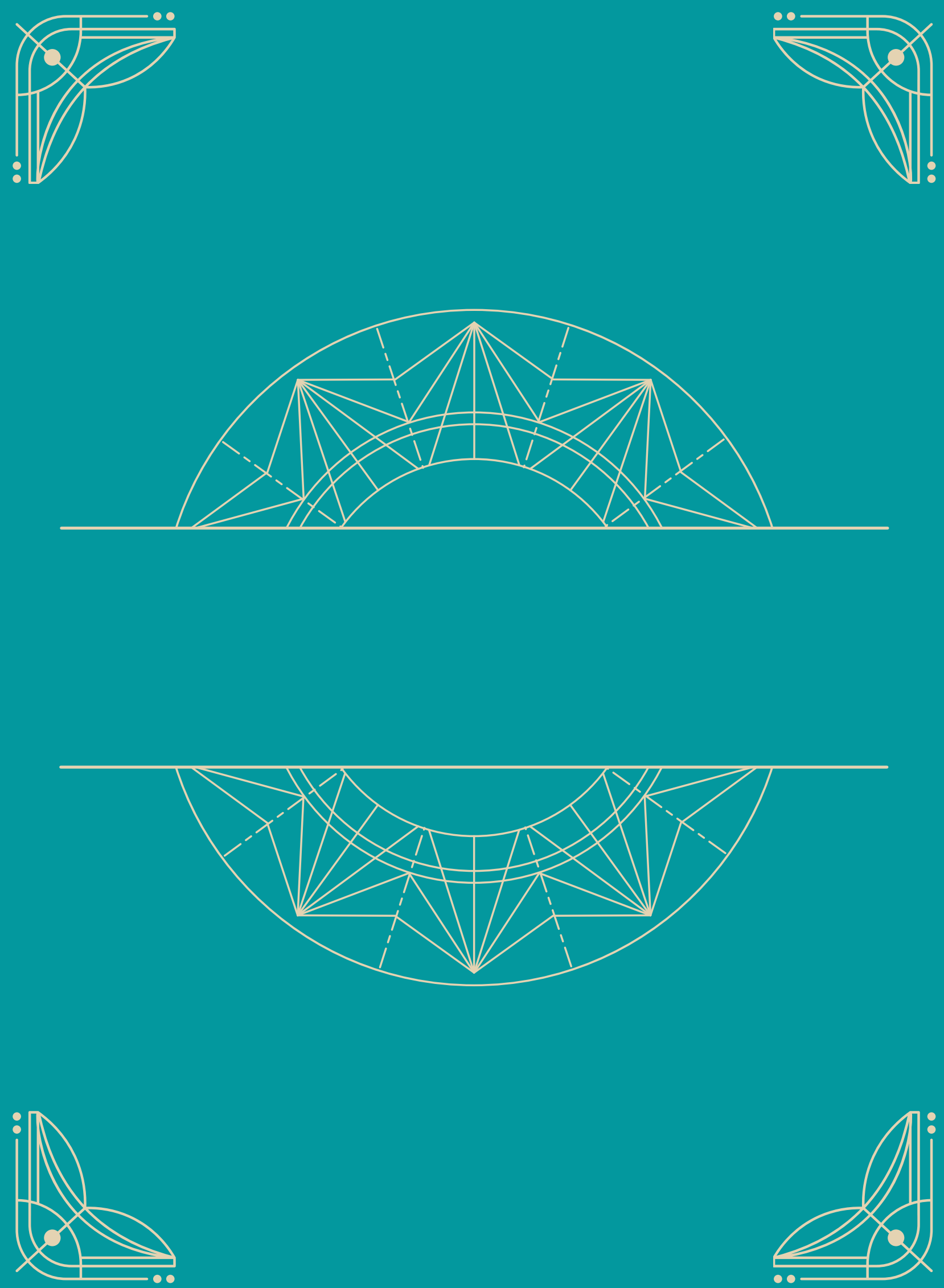